\title{
IMPROVEMENT OF THE LEGAL CULTURE AS A BASIS FOR THE FORMATION OF CIVIL SOCIETY OF MODERN TIMES
}

Collective monograph

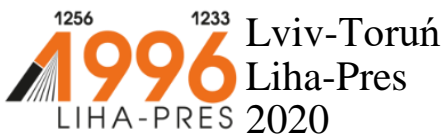




\section{Reviewers:}

Prof. dr hab. Sabina Grabowska, Uniwersytet Rzeszowski / University of Rzeszow (Republic of Poland);

Prof. $d r$ hab. Joanna Marszalek-Kawa, Uniwersytet Mikołaja Kopernika w Toruniu / Nicolaus Copernicus University (Republic of Poland).

Improvement of the legal culture as a basis for the formation of civil society of modern times : collective monograph / O. Borschevska, O. Boryslavska, I. Kharaberiush, O. Krushnitska, etc. - Lviv-Toruń : Liha-Pres, 2020. - $164 \mathrm{p}$.

ISBN 978-966-397-191-9

Liha-Pres is an international publishing house which belongs to the category "C" according to the classification of Research School for Socio-Economic and Natural Sciences of the Environment (SENSE) [isn: 3943, 1705, 1704, 1703, 1702, 1701; prefixMetCode: 978966397]. Official website www.sense.nl. 


\section{CONTENTS}

LEGAL ASPECTS OF REGULATION OF TITLE UKRAINIAN PEOPLE ON THE GROUND IN PERSPECTIVE REFORMING LAND RELATIONS IN UKRAINE

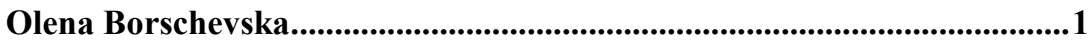

CONSTITUTIONAL DEVELOPMENT OF MODERN

UKRAINE: WANDERING IN A CIRCLE? SOME ISSUES

OF THE CONSTITUTIONAL SYSTEM FUNCTIONING

Olena Boryslavska

SPECIAL TECHNIQUE AS A CATEGORY

OF LEGAL SCIENCE

Ivan Kharaberiush.

EUROPEAN STANDARDS FOR ACCESS

TO PROFESSIONAL LEGAL ASSISTANCE

AND ENFORCEMENT ISSUES IN UKRAINE

Oksana Krushnitska

DEFECTS OF LEGAL TECHNIQUE AND POSSIBLE WAYS OF THEIR OVERCOMING IN THE REGULATION OF THE FORMATION OF PHYSICAL EVIDENCE AND SOLVING THE ISSUE ABOUT THEM IN THE CRIMINAL PROCESS OF UKRAINE Iryna Krytska 


\section{THE PRINCIPLE OF LEGALITY AS A FOUNDATION OF MODERN CIVIL SOCIETY}

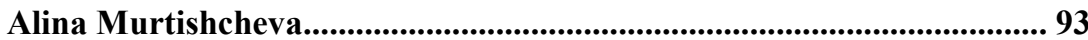

IMPROVEMENT OF SOCIETY LEGAL CULTURE AS A BASIS FOR INCREASING TRANSPARENCY AND ACCOUNTABILITY OF THE JUDICIARY TO UKRAINIAN SOCIETY

Vitalina Novoselova.......................................................................................... 110

AREAS OF PUBLIC ORGANIZATIONS' INFLUENCE ON LEGAL CULTURE AS A BASIS FOR CIVIL SOCIETY FORMATION: THEORETICAL AND LEGAL PREMISES

Larysa Udovyka 133 


\section{LEGAL ASPECTS OF REGULATION OF TITLE UKRAINIAN PEOPLE ON THE GROUND IN PERSPECTIVE REFORMING LAND RELATIONS IN UKRAINE}

\section{Olena Borschevska}

\section{INTRODUCTION}

The urgency of the work is due to the fact that nowadays the whole Ukrainian people are facing the urgent issue of opening the market / circulation of land. However, very little attention is paid to the exercise and protection of land ownership for the Ukrainian people and not for individual citizens of Ukraine. Due to the peculiarity of the subject of such property right, there is a need for a thorough study and determination of the possibility for the present legal regulation of the exercise of the property rights of the Ukrainian people for natural resources, in particular land.

Therefore, the purpose of this work was to investigate and highlight problematic issues in the exercise by the Ukrainian people of their property rights in general, and in particular, land.

The formulation of such a goal led to the following research objectives:

- identification of the property rights of the Ukrainian people;

- defining the concept of property rights of the Ukrainian people through the conceptual apparatus of civil legal instruments;

- applied coverage of the issues of opening the market / land circulation in the light of the exercise of land ownership by the Ukrainian people.

The object of the research is the system of legal relations that are formed in the process of exercising the property right of the Ukrainian people.

The subject of the research is the property of the Ukrainian people as the right of the community of citizens of Ukraine of all nationalities to own, use and dispose of land, its subsoil, atmospheric air, water and other natural resources within the territory of Ukraine, the natural resources of its continental shelf, exclusive (marine) economic zones, which are objects of property rights of the Ukrainian people.

The methodological basis of the study is the totality of general scientific, special scientific, as well as philosophical methods and techniques of scientific knowledge.

The research used the work of such scientists as, O.V. Dzera, I.O. Ivanov, A.V. Kovalenko, I. Kresina, N.S. Kuznetsova, V.V. Nosik, O.O. Pervomaisky, I.M. Perchekliy, M.P. Orzich, O.F. Skakun, I.V. Snicar, O. Stoyko and others. 
The regulatory framework for the study was the normative acts in force today, such as the Constitution of Ukraine of June 28, 1996 (as amended); The Land Code of Ukraine of October 25, 2001 (as amended); The Civil Code of Ukraine of January 16, 2003 (as amended); The Law of Ukraine "On the Procedure for Allocating in Land (on the Territory) Land Plots to Owners of Land Shares (share)" on the Use of Unallocated and Unclaimed Land Plots and Land Shares (share) of 5 June 2003, as amended; .The Law of Ukraine "On Amendments to Certain Legislative Acts of Ukraine on Resolving the Issue of Collective Land Ownership, Improvement of Land Use Rules in Agricultural Land, Prevention of Raiding and Encouragement of Irrigation in Ukraine". Of July 10, 2018 No. 2498-VIII; Draft Law of Ukraine "On Amendments to Certain Legislative Acts of Ukraine Concerning the Conditions of Circulation of Agricultural Lands" as amended for the second reading 03.01.2020 No. 2178-10.

Also interesting is the submission to the Constitutional Court of Ukraine of 46 People's Deputies on the interpretation of the provisions of the first sentence of part one of Article 13 and part one of Article 14 of the Basic Law, which deals with the ownership of the Ukrainian people on land.

\section{Civil Law Aspect of Determining the Legal Status of Property Rights of the Ukrainian People}

The main emphasis of almost all scholars who study the problem of property of the Ukrainian people is the conclusion that only the ecological and legal status of such property rights and, in some cases, the political context of such a legal institute. The imperfection of the legislative framework is the key to this. Thus, A. Dzera believes that the property right of the Ukrainian people is not an independent form of property and is, by its nature, state property, subject to the state of Ukraine and territorial communities, referring to Article 2 of the Civil Code of Ukraine, which reads that individuals and legal entities, as well as public entities such as the State of Ukraine, the Autonomous Republic of Crimea, territorial communities, foreign states and others, are participants in civil relations ${ }^{1}$. It is not possible to disagree with this statement, since the reference to an article of the law justifying one or another position on the basis of ownership is impossible. That is, it is impossible to justify natural law by law. Because the law must be justified by law according to the rule of law. The law should be an expression of law, but unfortunately, the legislator does not always reproduce the in-depth substance of law in legislative acts.

1 Енциклопедія цивільного права України (2009). Ін-т держави і права ім. В.М. Корецького НАН України; відповід. ред. Я.М. Шевченко. (рр. 664). Київ : Ін Юре 
Therefore, it is considered necessary to find out in what legal status the state in the person of state bodies and territorial communities in the person of bodies of local self-government realizes the property right of the Ukrainian people.

It follows from the Constitution that, the Ukrainian people, are citizens of Ukraine of all nationalities united by the legal connection of a person with the state, its affiliation with Ukraine, regardless of ethnic origin ${ }^{2}$. Thus, S.O. Komarov notes that citizenship is understood as membership of the state not as a union of all, but as a union of individuals who are in a stable, permanent, specific political and legal connection with the state. That is why it is the citizens who ensure the succession of a democratic state from generation to generation ${ }^{3}$.

In the general theoretical definition given by O.F. Skakun state is a sovereign political-territorial organization of a society with power, exercised by the state apparatus on the basis of legal norms that ensure the protection and reconciliation of public, group and individual interests with the restraint, if necessary, of legal coercion ${ }^{4}$. Society O.F. The steed calls the system of social community of people, which is created on the basis of mutual interests, mutual cooperation. It is supported by I. Kresina, O. Stoyko, arguing that the state is a collection of people who live in a certain territory organized and represented by a single authority ${ }^{5}$. But such an administrative and legal definition of the state should be harmonized with the civil law principles, since the state, according to Article 2 of the Civil Code of Ukraine, is a party to the civil legal relations. As N. Kuznetsova states, the state is not entitled to apply its own powers to legally equal subjects of these relations ${ }^{6}$, since this is contrary to the basic principle of civil law regarding equality of parties.

It follows from Article 2 of the Civil Code that territorial communities are also subject to civil law. Unfortunately, there is no clear legislative concept of the territorial community. Among scholars, the most common is the definition of territorial community M.P. Orzikh. As he considered, the social basis of self-governing territories is a territorial collective (a community, more precisely - a commune, in view of the regime of communal property in Ukraine and world experience), consisting (unlike the population of territorial units) of persons - citizens, foreigners, persons without nationals who are

${ }^{2}$ Конституція України прийнята на п’ятій сесії Верховної Ради України. (28.06.1996). Retrieved from https://zakon.rada.gov.ua/laws/show/254

${ }^{3}$ Комаров С.А. (1998) Общая теория государства и права. (рp. 81). Москва: Юрайт

${ }^{4}$ Скакун О.Ф. (2001) Теорія держави і права. Харків: Консум. Рр. 39.

${ }^{5}$ Енциклопедія цивільного права України (2009). Ін-т держави і права ім. В.М. Корецького НАН України; відповід. ред. Я.М. Шевченко. (рp. 664). Київ : Ін Юре

${ }^{6}$ Комаров С.А. (1998) Общая теория государства и права. (рр.81). Москва: Юрайт 
permanently resident or working in the territory (or who hold real estate in the territory or are taxpayers) ${ }^{7}$.

As M.V. Shulga The Ukrainian people, being the subject of property rights, refers to public entities. It is a certain community and acts as one, though it is made up of individuals and their groups ${ }^{8}$.

But for the sake of fairness and legal certainty, it should be clarified that in order to define the Ukrainian people, in the Preamble, the Ukrainian Constitutions are citizens of Ukraine of all nationalities. Therefore, the state and territorial communities, represented by state bodies and local selfgovernment bodies, should perform their functions of representation in asserting the property rights of the Ukrainian people only on behalf and, of course, in the interests of citizens of all nationalities. Here, too, there should be no opinion about the neglect of the rights of foreigners and stateless persons, since this is the exclusive property right of the Ukrainian people, which is mentioned in the Declaration on State Sovereignty of Ukraine of July 16, 1990. That is, the legislator declares to the Ukrainian people exclusive powers of exercising property rights, which, unfortunately, have not yet been given legislative consolidation.

As stipulated in Article 13 of the Constitution of Ukraine and Article 324 of the Civil Code of Ukraine, "on behalf of the Ukrainian people, the rights of the owner shall be exercised by state authorities and local self-government bodies". In this case, the state bodies and local self-government bodies perform the representative function of the state and the territorial community accordingly, which enables the state and the territorial community to dispose of the property rights of the Ukrainian people on its behalf, but it does not specify in any interests. Instead, it is interesting to draw attention to Article 326 of the Civil Code of Ukraine "State Property Law", namely to Part 2 "On behalf of and in the interests of the State, Ukraine shall exercise its right of ownership respectively by public authorities". The key phrase in this case is "in the interest". The question arises whether or not intentionally missed is a similar phrase in the article that regulates the property of the Ukrainian people.

It is known a priori that the category of "property right" belongs to the conceptual apparatus of civil, commercial law and the like. That is, private-law branches of law. It is known, and it is stated in the Constitution of Ukraine and

${ }^{7}$ Орзіх М. П.( 1995) Концепція правового статусу самоврядних територій і органів місцевого самоврядування. Місцеве та регіональне самоврядування України, № 1, 67.

${ }^{8}$ Шульга М.В, Устименко В.А. (2019) Землі як об'єкт земельних відносин: матеріали Всеукраїнської науково-практичної конференції (29 листопада 2019 р., м. Київ). Об'єкти екологічного і суміжних галузей права: теоретичні та практичні аспекти в умовах сталого розвитку. (рр.67) Київ: НАН України. Ін-т економіко-правових досліджень. 
in the Civil Code of Ukraine, that all owners are equal before the law. This also follows from the principles of civil law enshrined in Article 3 of the Civil Code of Ukraine. That is, relations of power-conquest that are inherent in the publiclaw branches of law cannot be fully transferred to relations of the exercise of property rights, since they are by their nature civil-law.

In civil law, there is a principle of equality of parties, according to which all subjects of civil law: the Ukrainian people, legal and natural persons, territorial communities and the state of Ukraine are equal and act in civil legal relations on equal terms.

Equally important is the principle of justice, which must be taken into account in relations with the Ukrainian people regarding the enjoyment of their property rights. Thus, R. Dvorkin believed that "justice is of legal importance, naturally, because of its key idea of equality. Equality can act as a right. The most fundamental of all rights is the interpretation of the right to equality in some way" "This principle of relations of the exercise of the property of the Ukrainian people by state bodies on behalf of the people of Ukraine should contain a rule regarding the consideration and interests of the Ukrainian people. This is a very important definition of civil law with regard to the provisions of representation which the state must, in essence, fulfill in exercising the property right of the Ukrainian people.

According to the doctrine of the civil law of Ukraine, the concept of ownership has a stable meaning, which does not change with the change of the subject of ownership. That is, under Article 317 of the Civil Code of Ukraine, the owner owns the rights to own, use and dispose of his property. Moreover, from the legal analysis of Article 324 of the Civil Code of Ukraine "Property of the Ukrainian People" it can be argued that the Ukrainian people are the subject of civil legal relations in the exercise of their property rights. Considering the issues in the civil law perspective, it should be noted that, of course, the Ukrainian people as a community, acting as a whole, consisting of individuals, are not able to exercise all their powers independently, since actions to exercise their owner's rights must be coordinated with each other. That is why the legislator rightly introduced the formula for which the Ukrainian people exercise their rights through the state and territorial communities in the person of state bodies and local self-government bodies. But it is not stated anywhere that the state and territorial communities can use the property of the Ukrainian people for their own benefit, that is, to exercise the property right of the Ukrainian people on behalf of the people, but not in its interests.

\footnotetext{
${ }^{9}$ Дворкін Р. (2001) Серйозний погляд на права. (pp. 12). Київ : Основи.
} 
The question arises which may be of interest to the Ukrainian people in the exercise of their property rights. Scientists believe that the interests of the Ukrainian people in the exercise of their property rights contribute only to ensuring the ecological security of the country, the conservation of natural resources for the benefit of present and future generations of citizens of Ukraine, the people as a whole, as well as addressing all issues related to possession and disposal these resources are under your direct control and direct involvement ${ }^{10}$. In other words, environmental and public-law interests are distinguished, which is indeed the case. But ownership, as a civil law category, has an economic component that mediates the material interest of the owner, which he can gain from owning, using and disposing of his property. Therefore, to the signs of the property rights of the Ukrainian people, offered by AO Pervomaiskyi, namely: the absolute nature of the property right of the Ukrainian people; the immutability of his subject; invariance of its contents; impossibility of termination or restriction by any laws ${ }^{11}$ should be added such features that would characterize the property of the Ukrainian people as a civil legal category. Such features should be: the material interest of the owner, that is, the Ukrainian people, in obtaining material benefits and the civil legal representation of the state and territorial communities towards the Ukrainian people, acting on behalf and in the interests of the Ukrainian people.

The legal status of objects that by their very nature should only be owned by the Ukrainian people should be spelled out at the legislative level.

Thus, it is expedient to consolidate at the legislative level the concept of property rights of the Ukrainian people in the civil law aspect, not through Article 324 of the Civil Code of Ukraine, but through the conceptual apparatus of civil legal instruments, which includes precisely the specific features of the property rights of the Ukrainian people.

Therefore, the property right of the people of Ukraine is the exclusive right of the community of citizens of Ukraine of all nationalities to own, use and dispose of land, its subsoil, atmospheric air, water and other natural resources

${ }^{10}$ Перчеклій I.M. (2015) Право власності українського народу на природні ресурси: еколого-правові засади. Автореферат дисертації на здобуття наукового ступеня кандидата юридичних наук за спеціальністю 12.00.06 - земельне право; аграрне право; екологічне право; природоресурсне право. (рp. 11) Київ.; Калініченко З.Д. (2016) Питання законодавчого забезпечення права власності на природні ресурси./ Захист права власності Українського народу: вітчизняні реалії та зарубіжний досвід для України. Матеріали I Щорічної міжнародної науково-практичної конференції (22 вересня 2016 року). (р. 130). Київ: Національна академія прокуратури України.

${ }^{11}$ Спасибо-Фатєєва I.B. (Ed) Цивільний кодекс України: Науково-практичний коментар. Пояснення, тлумачення, рекомендації з використанням позицій вищих судових інстанцій, міністерства юстиції, науковців, фахівців (2011) Том. 5. (рp. 42). Харків: ФОП Лисяк Л.С. 
within the territory of Ukraine, the natural resources of its continental shelf, exclusive (marine) economic zone, as well as scientific achievements, national, cultural and historical values, including those located outside Ukraine, which are the property of Ukrainian property. whom people. Representation on the competences of the Ukrainian people as an owner on his behalf and in his interests shall be exercised by state authorities and local self-government bodies within the limits specified by the Constitution of Ukraine.

\section{Legislative improvement of the relationship between the ownership of the Ukrainian people on land and the right of private ownership of land by a natural person - a citizen of Ukraine}

In the previous section, we considered some aspects of the property rights of the Ukrainian people through the conceptual apparatus of civil legal instruments. As already noted, the Ukrainian people have the right to own, use and dispose of other natural resources of land, that is, the Ukrainian people have the right of ownership of natural resources, in particular land.

It should be determined that land, by virtue of its properties and peculiarities of existence, is an object that can not be considered only in the plane of one legal concept or legal science. Land is a unique object of legal regulation, the national wealth of Ukraine. Therefore, first, and this is very important, the land in the understanding of the territory in the constitutional-legal aspect, is in essence one of the features of the state under constitutional law, that is, the land performs the most important function - the state-forming. But it should be emphasized that the Constitution of Ukraine introduces the concept of ownership of the Ukrainian people, that is, it operates with civil legal instruments, which becomes so decisive at the level with the constitutional feature of the land as the territory of the state. Thus, secondly, land is an object of civil law as a property with a special status to which the property of the Ukrainian people applies. Third, land becomes an object of agricultural law as an instrument of production without which any agricultural production is impossible; fourth, environmental law views land as a natural resource subject to state protection and protection against the negative impact of the environment. And so recently there is a debate among scientists that the legal status of the land has a social component. Its underestimation had a negative impact on the use of social levers of influence in establishing and implementing sustainable development ${ }^{12}$.

In this context, V. Golovchenko notes that the earth as a geographical category is the basis of the environment, all other natural objects and living creatures cannot exist outside its boundaries. In this sense, the earth's

\footnotetext{
12 Лібанова Е.М. (Еd) Соціально-економічний потенціал сталого розвитку України та іï районів (2014) Національна доповідь. ( pp. 108) Київ : ДУ “ІЕПСР НАН України”.
} 
biopotential has no other analogues and cannot be estimated in any monetary equivalent. Derivatives of the generic term "land" are other terms ("land resources", "land", "land relations", "land code", "land law", etc.).

Therefore, the question of the objective potential of the so-called land market / circulation in Ukraine, in particular, of agricultural land, becomes very urgent. According to statistics in Ukraine, agricultural land is almost 72 percent. This is a large part of the territory of the state. Moreover, these lands have high fertility, and thus potentially have high economic attractiveness.

To date, land relations in Ukraine are governed by such basic legislative acts as the Constitution of Ukraine, the Land Code of Ukraine, the Law of Ukraine "On the procedure for allocating in-kind (on the ground) land plots to owners of land parcels (shares)" regarding the use of unallocated and unclaimed land plots and land shares (units) dated June 5, 2003, as amended; .The Law of Ukraine "On Amendments to Certain Legislative Acts of Ukraine Concerning the Issue of Collective Land Ownership, Improvement of Land Use Rules in Agricultural Lands, Prevention of Raiding and Encouragement of Irrigation in Ukraine" of July 10, 2018 and others.

All of these pieces of legislation are intended to regulate land relations, but they appear to be even more confusing.

An indicator of this was the question of the present time regarding the opening of the market / circulation of agricultural land, which, as noted, constitutes more than $2 / 3$ of the total area of the state of Ukraine. Can the state freely dispose of the property of the Ukrainian people as its representative without the corresponding powers conferred on the state by the people. In the context of this issue, it is first and foremost necessary to link the tools of the various fields of law, since this question can be solved by using the methods of public law, including constitutional law. This will allow the people to express their opinion in the All-Ukrainian Referendum, since only such will of the people can be considered as legitimate granting of special powers to the state as a representative of the Ukrainian people. Thus, such representation of the interests of the state in relation to the Ukrainian people in matters of ownership will orient the state to fulfill its duties as a representative of the Ukrainian people in the civil legal plane. In due time, it was emphasized by O.M. Borshchevskaya, which determined the need to combine public-legal and private-legal principles of legal regulation of the property rights of the Ukrainian people ${ }^{14}$.

13 Головченко В. Земля: майно чи ресурс? Retrieved from http://yur-gazeta.com/ publications/practice/zemelne-agrarne-pravo/zemlya-mayno-chi-resurs-.html

14 Борщевська O.M. (2017), Нестеренко А.C. (Еd) Поєднання публічно-правових і приватноравових засад правового регулювання здійснення права власності українського народу. Процесс модернізації системи державного управління: конституційний, 
As it is rightly defined in the Constitutional submission on the official interpretation of the provisions of the first sentence of part one of part 13, part one of Article 14 of the Constitution of Ukraine in a systematic connection with the provisions of first part of the Preamble, provisions of Article 1, part two of Article 3, part two of Article 5, part 4 Article 13 of the Constitution of Ukraine in the Constitution (Articles 13, 14, 142) the concept of "land" is used in several meanings, namely as: the object of property rights of the Ukrainian people; object of property rights of citizens, legal entities and the state; the property of territorial communities. And given that land appears in different meanings given its versatile characteristics and purpose, there is a need to interpret the concept of land as an object of the property rights of the Ukrainian people and the main wealth under special protection of the state ${ }^{15}$.

Concerning the question of ownership of land of an individual, it can be noted that the ownership of land is acquired in several ways. As under civil law agreements (Article 131 of the Land Code of Ukraine), but it should be noted immediately that there is still a moratorium on the sale of agricultural land. And from birth every Ukrainian is guaranteed the right to free privatization of land. According to Article 121 of the Land Code ${ }^{16}$, citizens of Ukraine have the right to transfer land free of charge in the following sizes:

1) for farming in the size of the average land share (share) which is defined as the average of the village council or district (from 1.1 hectares in Ivano-Frankivsk region to 8.8 hectares in Lugansk region, on average across Ukraine -4 hectares );

2) for keeping a private peasant farm - no more than 2.0 hectares;

3) for gardening - no more than 12 acres;

4) for construction, maintenance of dwellings, outbuildings in villages up to 25 hectares, in settlements - not more than 15 hectares, in cities - not more than 10 hectares;

5) for individual cottage construction - no more than 10 acres;

6) for construction of individual garages - no more than 1 hectare.

Members of hostilities, including members of the ATO, in accordance with paragraph 14 of Article 12 of the Law of Ukraine "On the status of war

адміністративний та фінансовий аспекти: колективна монографія (рp.33-51). Одеса: Видавничий дім "Гельветика"

${ }^{15}$ Конституційне подання депутатів щодо офіційного тлумачення положень першого речення частини першої частини 13, частини першої статті 14 Конституції України у системному зв'язку із положеннями речення першого Преамбули, положень статті 1 , частини другої статті 3, частини другої статті 5, частини 4 статті 13 Конституції України. Retrieved from http://ccu.gov.ua/sites/default/files/3_6992.pdf

16 Земельний кодекс України (25.10.2001) Retrieved from https://zakon.rada.gov.ua/ laws/show/2768-14 
veterans, guarantees of their social protection" of October $22,1993^{17}$ have the right to a privilege - first of all land for individual housing construction, gardening and horticulture.

A citizen of Ukraine has the right to privatize six hectares of land during his lifetime. However, it is not enough to have the right, it is necessary to realize it also, having started registration of the land plot in the property.

And here is the question. Someone has land on the right of permanent use (for housing, personal or household shares, etc.), and someone is not able to exercise their right due to the lack of land territory relative to the population of Ukrainian citizens.

The legitimate dilemma arises whether or not such a rule of law is "dead"as that which does not have its own mechanism of legal regulation.

First of all, it should be noted that the fundamental principle of both constitutional law and civil law is the de jure equality of all citizens before the law. In fact, we get the opposite - inequality and injustice. Civil law tools should be used to avoid such distortions of the law. This concerns, first and foremost, the potential property right of an individual - a citizen of Ukraine for free privatization and the correlation of such right with the ownership of the Ukrainian people in this case on land. This can be interpreted as follows every citizen of Ukraine is a potential owner of a land plot, an area that is directly proportional to the number of citizens of Ukraine at a certain point in time and at the same time is a collective owner of land as a natural resource within the Ukrainian people. But the land resource is not infinite, and the number of citizens of Ukraine is constantly increasing. Therefore, the legal norm for free privatization of 6 hectares of land for different purposes for each citizen cannot be fulfilled for objective reasons.

The simplest but not legal measure would be to exclude such a rule from the legislation of Ukraine, but this would violate the principle of justice, which is a priority in the implementation of legal rules. Because, someone was able to exercise his right, and another citizen for the above reasons could not exercise that right. But the legal solution to this situation is through compensation. To do this, it is necessary to amend the Land Code of Ukraine, namely to supplement Article 121 of the Land Code of Ukraine with part 4 of the following content: destination - a citizen of Ukraine at the age of 18 has the right to apply to the relevant executive authority or local self-government body, which transfers land to the state or property ownership in accordance with the powers defined in Article 122 of the Code requesting compensation for the market value of the land on which he was entitled to free privatization.

${ }^{17}$ Про статус ветеранів війни, гарантії їх соціального захисту. (22.10. 1993) Закон України. Retrieved from https://zakon.rada.gov.ua/laws/show/3551-12 
Thus, any citizen of Ukraine would have the opportunity to defend their right to free privatization - or through substantive legal protection, having obtained a land plot in kind in the manner of privatization. Or because of a legal defense of such a right. This would also have a certain effect on the social protection of Ukrainian citizens.

It is clear that the legal mechanism for the implementation of this rule of law in by-laws should be described in the future. However, this would solve the gap in the legislation on the impossibility due to the lack of land plots to realize the right of every citizen of Ukraine to free privatization of land plots for a certain purpose.

Logically, another question arises. How does private ownership of land as an object of civil and land law relate to the ownership of the Ukrainian people on land as a natural resource. It should be noted that the common concept of natural resources is their definition as objects and systems of living and nonliving nature, components of the natural environment that surround the person, which are used in the process of social production to meet the material and cultural needs of man and society and ensure their livelihood. Therefore, the Ukrainian people as the owner of land resources have a special legal status in relation to the natural person - the owner of the land. Such relations can be deduced through Article 110 of the Land Code of Ukraine "The concept of restriction in the use of land plots, encumbrance of land rights". But first we need to consider what is the restriction and encumbrance of land rights.

According to Art. 2 of the Law of Ukraine "On the State Central History of True to Own Property and Their Restriction" 18 is a prohibition to perform and / or join its own property, which is established or established by law, or is usually used in the relevant public service which deals with strong responsibilities. contracts. Note that until recently, the concepts of "delay" and "restriction" have been used by different parts that have differently, very, in fact, defined the same jurisprudence. After the adoption of the Law of Ukraine "On the Transition to the Law of Ukraine" Centralized Real Rights to Real Estate Property and Their Violations Existed "and Other Legislative Acts of Ukraine dated 11.02.2010 No. 1878-VI. In such circumstances, the restoration of true truth to real estate is created as temporary or arbitrary additional necessary owners of enemies who decorate certain surveys when performing Orthodoxy from known own property. The truths obtained were not used by the various proprietors, but in the reduction of their orthodox persons, members and industries are impossible property or parts thereof. In your property, the property owner cannot adhere to the real anomaly of real property on his own property.

18 Про державну реєстрацію речових прав на нерухоме майно та їх обтяжень. (01.07.2004). Закон України року Retrieved from https://zakon.rada.gov.ua/laws/show/1952-15 
But these changes are not included in Articles 110, 111 and other Land Code of Ukraine. Due to this, the collective reliability of the legal ideal idea operates. We have 111 Land Code of Ukraine "Expansion of the true on the land plot, reduction in the internal land plot" does not remain a clear demarcation of what you need to have. But this, as used, is a false practice, but it is impossible to prevent the Ukrainian people from treating the right of an individual landowner to the deterioration of the land unity, its ministry, and to change its target value. As for the natural resource, the land should be a family and use it for a purposeful solution. Such unbounded reliability has diminished and it is observed that their organization is represented at the legal level, which made it possible to actually realize the ownership of the Ukrainian population on land in sufficient quantity. Thus, one can see the real truth about land as represented by the owner of land plots that protect the rights of the Ukrainian people on land as a natural resource. With profitable ownership of the land, the person should be that the land has a special natural resource, national wealth, which is within the Constitution of Ukraine and there is a mandatory ownership of the Ukrainian population on the land, the Ukrainian people support the right to survey the property rights of any - what kind of person on the land. Finding that land, like other natural resources, is a special object of law that exists as a national wealth, then the ownership of the land as a true civilian cannot be known that can be used in any case, as is the case with other objects. Therefore, the restriction of ownership should be taken into account as the owner of his own land uses his rights of the land owner to the extent that does not send the rights of people who should be excluded from the owners of their own land, which should be attributed to the rights of other persons to be determined. necessarily Orthodox. by a court decision. Such right can also be seen as the right of third parties (when, Article 659 of the Civil Code of Ukraine).

For this purpose the following amendments and additions to the legislative acts of Ukraine should be made:

1) Article 110 of the Land Code of Ukraine should be read in the following wording:

Article 110. Concept of Restriction in Use of Land Plots, Burden of Rights to Land Plot

"1. Restrictions may be imposed on the use of the land owner or part thereof.

The ownership of the land is burdened with the ownership of the Ukrainian people.

2. The transfer of ownership of land does not terminate the established restrictions, encumbrances. 
3. The division or consolidation of land does not terminate the encumbrance of the property of the Ukrainian people.

4. The division or consolidation of land shall not terminate the restrictions imposed on the land, except where the encumbrance extends only to a part of the land which, as a result of the division of the land, did not enter into the new land formed.

2) Article 111 of the Land Code of Ukraine should be read in the following wording:

Article 111. Burdening of rights to land, restrictions on land use:

1. The encumbrance of rights to land is established by the Constitution of Ukraine and other legislative acts as the property right of the Ukrainian people to natural resources. The owner of the land plot is forbidden to influence the deterioration of the fertility of the agricultural land plot, to harm the purpose of the land plot, to change the purpose of the land plot.

2. The law, adopted in accordance with it normative legal acts, contract, court decision may set the following restrictions on land use:

a) condition to start and finish building or development of the land plot within the set terms;

b) prohibition of conducting certain activities;

c) prohibition on changing the purpose of the land plot, landscape;

d) condition for the construction, repair or maintenance of the road, road section;

e) the condition of compliance with environmental requirements or performance of certain works;

e) conditions to grant the right to hunt, to catch fish, to collect wild plants on their land plot in due time and in due course;

(e) the obligation to maintain and preserve forest protective strips.

g) other

3. Burdening of rights to land does not require State registration as it is a constitutional right of the Ukrainian people and protected by law at the level of the Constitution of Ukraine.

4. Restrictions on the use of land (except for restrictions directly established by law and regulations adopted in accordance with them) shall be subject to state registration in the State Land Cadastre in accordance with the procedure established by law and shall be effective from the moment of state registration.

Restrictions on the use of land, directly established by laws and regulations adopted in accordance with them, shall be valid from the moment of entry into force of the legal acts which they were established.

5. Information on land use restrictions shall be specified in land management schemes and feasibility studies on the use and protection of land 
of administrative-territorial units, land management projects on the organization and establishment of boundaries of territories of nature reserve fund and other nature conservation, recreational, recreational, cultural and recreational purposes, forestry, land of water fund and water protection zones, restrictions on the use of land and their regime-forming objects, land use projects, providing ecological and economic assessment of crop rotation and ordering land, land management projects on land allocation, technical documentation land management on the establishment (renewal) boundaries of the land in kind (on location). Information on such restrictions shall be added to the State Land Cadastre.

3) To supplement Article 140 "Grounds for termination of ownership of land property" of the Land Code of Ukraine with the following points:

g) change of purpose of the land plot;

h) damage to the intended purpose of the land plot;

i) deterioration of the fertility of agricultural land or damage to other land.

4) In the Law of Ukraine "On State Registration of Property Rights to Real Estate and their encumbrances" the concept of "encumbrance" should be changed to "restriction" in order to harmonize legislative material with the Land Code of Ukraine and to rationally protect the ownership of the Ukrainian people on land.

\section{Problems of opening the market / land circulation in the aspect of exercising the right of ownership of land by the Ukrainian people and the right of private ownership of land by a natural person - a citizen of Ukraine}

At the present stage of the development of statehood in Ukraine, the question of market opening / land circulation in the state becomes urgent. This issue is rather acute in terms of the underdevelopment of the legislative framework. At present, this issue is becoming not only a legal one, but it is becoming a political one.

It is generally accepted that land, as a natural resource, has no value, but it has value because it is a national asset, as stated in the Constitution of Ukraine. This apartment can have both value and value. Therefore, we are not talking about the land market, but about its turnover.

Each state works for the development and growth of the economy, the increase of jobs, but it cannot be said that this will lead to the opening of the possibility of free sale of land by lifting the moratorium. This statement is false.

Land turnover is not an end in itself. The opening of free circulation of land should be the result of the reform, which will pass the stages of creating 
appropriate effective and transparent mechanisms for encouraging peasants to conduct agriculture, identify the priority of agricultural business. The mechanisms for granting preferential credits, tax breaks, demonopolizing the market and other incentives for the agricultural producer must first be earned and tested. And only if a positive economic result from the introduction of such innovative principles can be said about the possibility of lifting the moratorium on the burdens arising from the ownership of the Ukrainian people on land as a natural resource.

It should be noted that some steps are being taken in this direction by the Government of the country. The Bill "On Amendments to Certain Legislative Acts of Ukraine Regarding Conditions of Circulation of Agricultural Lands" 19 was prepared, but as of January 14, 2020, it did not pass the second reading in the Verkhovna Rada of Ukraine because it does not correspond to the realities of today and does not protect the rights of agricultural producers.

The Law of Ukraine "On Amendments to Certain Legislative Acts of Ukraine on Resolving the Issue of Collective Land Ownership, Improving Land Use Rules in Agricultural Land, Preventing Raiding and Promoting Irrigation in Ukraine in 2018" which came into force on January $1,2019^{20}$.

This Law has completely revised Article 13 of the Law of Ukraine "On the Procedure for Allocating Land (Units) in Land (Units) to Owners of Land Shares (Units)" of June 5, $2003^{21}$, which deals with the use of unallocated and unclaimed land and shares (Units). The law defines and demarcates the concepts of unallocated land and unclaimed land.

An unallocated land plot is a land plot, which according to the project of land management for the organization of the territory of land parcels (shares) was included in the area of land to be distributed, but in accordance with the protocol on the allocation of land plots was not allocated to the owner of the land share (share).

Unclaimed is a land share (share) for which no document confirming the right to it has been received, or a land share (share) entitled to it in accordance with the law, but which has not been allocated in kind (on the ground).

19 Про внесення змін до деяких законодавчих актів України щодо умов обігу земель сільськогосподарського призначення. (03.01.2020). Законопроект до другого читання. Retrieved from http://w1.c1.rada.gov.ua/pls/zweb2/webproc4_1?pf3511=66948

${ }^{20}$ Про внесення змін до деяких законодавчих актів України щодо вирішення питання колективної власності на землю, удосконалення правил землекористування у масивах земель сільськогосподарського призначення, запобігання рейдерству та стимулювання зрошення в Україні. (10.07.2018). Закон України. Retrieved from https://zakon.rada.gov.ua/ laws/show/2498-19

${ }^{21}$ Про порядок виділення в натурі (на місцевості) земельних ділянок власникам земельних часток (паїв). (05.06.2003). Закон України. Retrieved from https://zakon.rada.gov.ua/laws/show/ 899-15 
It is regulated that unallocated land plots, unclaimed shares (shares) after their formation into land plots by the decision of the respective village, settlement, city council may be leased for the purpose intended for the term up to the day of state registration of the ownership of such land plot, which is indicated in the lease of the land plot, and the owners of the land parcels (shares) or their heirs, who did not take part in the land plot allocation, are informed about the results of the land division conducted parcels in writing registered letter with an inventory and return receipt or by delivery of a notification in person, knowing their location.

The deadline for registration of the ownership right of the owner (his heir) of the unclaimed land share (share) is also set in case if by 1 January 2025 the owner of the unclaimed land share (share) or his heir did not register the ownership of the land, he is considered to have refused from the receipt of land. And under the norms of civil law, such unclaimed land share (share) after its formation in the land plot by the decision of the respective village, settlement, city council (in case of need of formation) by the application of the relevant council on the basis of the court decision is transferred to the communal property of the territorial community in the territory of which it is located, in the order of recognition of the property as landless.

However, in case of missing the term for registration of the ownership of the land plot for good reason on the claim of the owner of the unclaimed land share (share) or his heir, the court may determine an additional term sufficient for such registration. In the absence of agricultural lands of collective ownership, such land share (share) may be allocated in kind (on the ground) at the expense of land of communal property of the respective territorial community (if such lands exist).

Within 7 years from the date of state registration of the communal property right to the land plot formed from the unclaimed land share (share), it is prohibited to transfer it to private property (except for the transfer to the owner of the unclaimed land share (share) or his heirs).

Such a law would be considered a breakthrough and a step towards moving the land reform forward, but the following should be considered.

First, as already mentioned, it is possible to obtain land of no more than 6 hectares for all types of purpose for free privatization of land. Such a right may already be exercised by a person, and the land share may exceed that size. The Law and any other normative act do not prescribe the legal mechanism of settlement and monetary relations regarding the transfer of such land shares (shares) to the owner or his heirs. Therefore, it is logical to assume that such an excess amount of land area (share) that was not included in free privatization can be obtained only for money. 
According to statistics, it should be noted that the World Bank Director for Ukraine, Belarus and Moldova, Satu Kahkonen, stated that the poverty rate in Ukraine has increased by 10 percent over the past five years and that 25 percent of the population is below the poverty line ${ }^{22}$. Therefore, the question arises whether the owner of the land (shares) or his heir at market price can issue the ownership right to it, especially since the limit of such actions expires on January 1, 2025.

Currently, there is no mechanism in the state to obtain cheap targeted loans to obtain funds for the registration of ownership of their land shares (units). And to a greater degree of injustice in the Law it is determined that if the owner has not exercised such a right within a specified period, then it is considered that he has relinquished his land share (share) and such property is recognized as homeless and transferred to communal property. The legislator assumes that a person for the next 7 years, that is, until January 1, 2032, will be able to find the funds to execute the ownership right, so he imposes a restriction of 7 years from the date of state registration of the communal ownership of the land plot to transfer it into private ownership to another person, except transfer to the previous owners of such unclaimed land (share) or his heirs. But the law does not prohibit the transfer of such land for rent to other persons with all its consequences, such as the right of priority purchase of leased property (Article 777 of the Civil Code of Ukraine).

Thus, the new wording of Article 13 of the Law of Ukraine "On the Procedure for Allocating Land (Units) in Land (Units) to Owners of Land Shares (Units)" of 5 June 2003 may in essence become an instrument that will allow for the removal of land (shares) by their owners. for objective reasons, they will not be able to draw up properly. And property rights will be violated by law. But this cannot be allowed in the rule of law.

It should also be noted that in view of the current jurisprudence it is impossible to count on obtaining ownership of a land plot (share) in accordance with Article 119 of the Land Code of Ukraine due to statute of limitations. Thus, the Supreme Court of Ukraine, having analyzed Article 119 of the Land Code of Ukraine, stated that this rule gives grounds to conclude that for citizens who conscientiously, openly and continuously use the land plot for 15 years, but do not have documents proving their rights there are no advantages to this land, since even observance of all conditions of limitation does not lead to the emergence of ownership of the land and actually sends to the general order of the provision of land in property or use (Articles 118, 123 of the Land Code of Ukraine). This provision provides only the right to apply

\footnotetext{
22 Економічна правда. (11.10.2018) Retrieved from https://www.epravda.com.ua/ publications/2018/10/11/641524/
} 
to a public authority or local self-government with a request for the transfer of a land plot to property or use and does not provide for the mandatory transfer of a land plot to the property or use of such persons, in accordance with the procedure prescribed by law and the submission of necessary documents ${ }^{23}$.

That is, if you wish to acquire ownership of a land plot that is in communal or state ownership, it is in principle indifferent that a person has used it openly and in good faith for 15 years or more. One way or another, the person should apply to the local self-government body or public authority and to acquire the ownership of the land within the limits of the free transfer of land determined by Article 121 of the Land Code of Ukraine in accordance with the procedure established by the Land Code of Ukraine. In doing so, the competent authority may refuse to acquire the right of the applicant on the grounds provided for by the Land Code of Ukraine despite the open and fair use of the land plot for more than 15 years.

In view of this, it is possible to propose to the legislator, to regulate at the legislative level the position that if a citizen does not have objective possibilities for registration of the ownership of the land (share) he received legally, then it cannot be restricted in this right by specific terms. Such land (share) must remain with the citizen in permanent use with all the rights arising therefrom and the possibility for him or his heirs to register the ownership of it in accordance with the law without any time limit. That is the idea that should be the basis for the amendment of Article 13 of the Law of Ukraine "On the Procedure for Allocating Land to Owners of Land Shares (Units) in kind (on the ground)"of 5 June 2003.

General ideas on land reform should also be outlined, in terms of opening up land circulation in Ukraine, which need to be finalized by the legislature to prevent abuse in this area. Here it should be remembered that land is not a commodity. A commodity is what a person's work is attached to. Therefore, some scientists believe that they are not selling land but the right to use the land. Therefore, it is more appropriate not to talk about the land market, but about its turnover. These are conceptual concepts that will need to be substantiated in the discussion process.

It should be borne in mind, as already stated above, that land has a stateforming function and therefore it should belong only to the citizens of Ukraine and no ephemeral investments from foreign countries can be an excuse for opening land circulation to them. Land resources are the property of the Ukrainian people and therefore the fate of the land turnover should be decided only on the initiative of the people in the All-Ukrainian referendum on the correct questions, not through sociological polls.

23 Постанова Верховного Суду України. Касаційного цивільного суду, справа № 742/2916/15-ц (11.04.2018). Retrieved from http://reyestr.court.gov.ua/Review/73627618 
In view of the above, the circulation of agricultural land may be opened with the possibility of obtaining agricultural land for ownership only to persons of Ukraine who permanently reside in Ukraine in rural areas at the place of regional registration and intend to use it for their intended purpose (as noted, non-compliance of this requirement for targeted use of land will be the basis according to the amendments to Article 140 of the Land Code of Ukraine termination of ownership of such land and removing it from the face).

The thesis that deserves attention is M.V. Shulga, who notes that it should be borne in mind that today some citizens of western Ukraine have obtained the citizenship of neighboring states, while retaining the citizenship of Ukraine. Residents of Donetsk and Lugansk regions have the decree of the President of the Russian Federation to obtain the citizenship of the Russian Federation in a simplified manner. Finally, Ukraine's willingness to grant citizenship to ethnic Ukrainians without giving up citizenship of another country should also be taken into account. The combination of the above factors can create a situation that can cause the danger of loss of territorial integrity of our state. This cannot be allowed, since territorial integrity ensures the independence of any state ${ }^{24}$.

Therefore, it is reasonable to take into account the idea that in the case of land reform, if a citizen of Ukraine moves to a permanent residence in another country or if he becomes a bipatrid (a person with dual citizenship, which by the way is currently prohibited for citizens of Ukraine), the land becomes communal property territorial community or state property with potential compensation to the person for its value. Then such land can be legally transferred to another agricultural producer from among the citizens of Ukraine.

Before opening the free circulation of agricultural land, it is necessary to adopt a number of legal acts that would allow peasants who wish to obtain ownership of the land (share) to have the most favorable financial conditions for it - loans, installments, preferential holidays, etc.

The state and local self-government bodies should have control over the functions of land use for its intended purpose without interfering with the economic activities of agricultural producers.

There should be a reasonable restriction on the allocation of land to property, which will be deducted from the profitability formula of farming in a particular locality in the production, processing and sale of agricultural products - giving preference to small and medium-sized farms.

${ }^{24}$ Шульга М.В, Устименко В.А. (Еd) (2019) Землі як об’єкт земельних відносин: матеріали Всеукраїнської науково-практичної конференції (29 листопада 2019 р., м. Київ). Об'єкти екологічного і суміжних галузей права: теоретичні та практичні аспекти в умовах сталого розвитку. (рp. 67) Київ: НАН України. Ін-т економіко-правових досліджень. 


\section{CONCLUSIONS}

The research on the legal aspects of regulating the ownership of the Ukrainian people on land in the light of the reform of land relations in Ukraine and the results obtained on it are aimed at solving a scientific problem, consisting in the development of new theoretical and applied provisions on the protection and property rights of the Ukrainian people and its implementation within the framework of land reform in Ukraine. It should be noted that some issues have only been flagged as they require more sophisticated elaboration on in-depth case study.

In particular, the study formulates the following main conclusions:

1. The ownership of the Ukrainian people on land as a natural resource is an integral, guaranteed by the Constitution of Ukraine and must be taken into account in land relations in the process of land reform.

2. To take into account the will of the Ukrainian people solely through holding an All-Ukrainian referendum, not through sociological polls.

3. The circulation of agricultural land may be opened with the possibility of obtaining land for ownership only to persons of Ukraine who permanently reside in Ukraine in rural areas at the place of regional registration and intend to use it for their intended purpose.

4. In case of departure of a citizen of Ukraine to a permanent place of residence in another state or if he becomes a bipatrid (a person with dual citizenship, which by the way is currently forbidden for citizens of Ukraine), the land becomes a communal property of the territorial community or state property with possible compensation to the person of it. cost. Then such land can be legally transferred to another agricultural producer from among the citizens of Ukraine.

5. Amend the legislation of Ukraine providing for the introduction of concepts of encumbrance and restriction, with a clear legislative definition. The notion of burdening the rights to land is a constant duty of the land owner to take into account the Ukrainian people's rights to land as a natural resource as a basis for differentiation of concepts. And the restriction of the property right should be defined as the obligation of the land owner to exercise his rights of the land owner within the limits that do not violate the rights of other persons, that is, the restriction of the rights of the land owner follows from the rights of another person, which are defined by normative legal acts, contract or court decision.

6. To supplement the list of grounds for termination of ownership of land in Article 140 of the Land Code of Ukraine by the following points:

g) change of purpose of the land plot;

h) damage to the intended purpose of the land plot; 
land.

i) deterioration of the fertility of agricultural land or damage to other

6. Improve Article 13 of the Law of Ukraine "On the Procedure for Allocating in Land (on the Territory) Land Plots to Owners of Land Shares (Units)"of June 5, 2003, by the provision that a citizen who has no objective possibilities for registration of ownership rights to the land (share) he received legally cannot be limited in this right by a specific timeframe. Such land (share) must remain with the citizen in permanent use with all the rights arising therefrom and the possibility for him or his heirs to register the ownership of it in accordance with the law without any time limit.

7. The state and local self-government bodies should have control over the functions of land use for its intended purpose without interfering with the economic activities of agricultural producers.

\section{SUMMARY}

The article deals with the problematic issues of exercising the property right of the Ukrainian people in light of the land reform announced by the Government of Ukraine in 2019. The urgency of the work is due to the fact that nowadays the whole Ukrainian people are facing the urgent issue of opening the market / circulation of land. However, very little attention is paid to the exercise and protection of land ownership for the Ukrainian people and not for individual citizens of Ukraine. Due to the peculiarity of the subject of such property right, there is a need for a thorough study and determination of the possibility for the present legal regulation of the exercise of the property rights of the Ukrainian people for natural resources, in particular land. The article identifies the property rights of the Ukrainian people, defines the concept of property rights of the Ukrainian people through the conceptual apparatus of civil legal instruments; Applied coverage of the problem of opening land circulation in the light of the exercise of land ownership by the Ukrainian people is provided in accordance with the existing legislative acts and proposed bills. It also offers suggestions for the rational and expedient exercise of its property right by the Ukrainian people through the social-legal component of such right.

\section{REFERENCES}

1. Конституція України прийнята на п'ятій сесії Верховної Ради України. (28.06.1996). URL: https://zakon.rada.gov.ua/laws/ show/254

2. Земельний кодекс України (25.10.2001) URL: https://zakon.rada.gov.ua/ laws/show/2768-14

3. Про статус ветеранів війни, гарантії їх соціального захисту. (22.10.1993) Закон України. URL: https://zakon.rada.gov.ua/laws/ show/3551-12 
4. Про порядок виділення в натурі (на місцевості) земельних ділянок власникам земельних часток (паїв). (05.06.2003). Закон України. URL: https://zakon.rada.gov.ua/laws/show/899-15

5. Про державну реєстрацію речових прав на нерухоме майно та їх обтяжень. (01.07.2004). Закон України року URL: https://zakon.rada.gov.ua/ laws/show/1952-15

6. Про внесення змін до деяких законодавчих актів України щодо вирішення питання колективної власності на землю, удосконалення правил землекористування у масивах земель сільськогосподарського призначення, запобігання рейдерству та стимулювання зрошення в Україні. (10.07.2018). Закон України. URL: https://zakon.rada.gov.ua/ laws/show/2498-19

7. Постанова Верховного Суду України. Касаційного цивільного суду, справа № 742/2916/15-ц (11.04.2018). URL: http://reyestr.court.gov.ua/ Review/73627618

8. Про внесення змін до деяких законодавчих актів України щодо умов обігу земель сільськогосподарського призначення. (03.01.2020). Законопроект до другого читання. URL: http://w1.c1.rada.gov.ua/ pls/zweb2/webproc4_1?pf3511=66948

9. Конституційне подання депутатів щодо офіційного тлумачення положень першого речення частини першої частини 13, частини першої статті 14 Конституції України у системному зв'язку із положеннями речення першого Преамбули, положень статті 1, частини другої статті 3 , частини другої статті 5, частини 4 статті 13 Конституції України. URL: http://ccu.gov.ua/sites/default/files/3_6992.pdf

10. Борщевська О.M. (2017), Нестеренко А.С. (Еd)Поєднання публічно-правових і приватноравових засад правового регулювання здійснення права власності українського народу. Процесс модернізації системи державного управління: конституційний, адміністративний та фінансовий аспекти: колективна монографія (pp. 33-51). Одеса: Видавничий дім "Гельветика".

11. Головченко В. Земля: майно чи ресурc? URL: http://yur-gazeta.com/ publications/practice/zemelne-agrarne-pravo/zemlya-mayno-chi-resurs-html

12. Дворкін Р. (2001) Серйозний погляд на права. (pp. 12). Київ : Основи.

13. Економічна правда. (11.10.2018) URL: https://www.epravda.com.ua/ publications/2018/10/11/641524/

14. Енциклопедія цивільного права України (2009). Ін-т держави i права ім. В.М. Корецького НАН України; відповід. ред. Я.М. Шевченко. (рp.664). Київ : Ін Юре. 
15. Калініченко 3.Д. (2016) Питання законодавчого забезпечення права власності на природні ресурси./ Захист права власності Українського народу: вітчизняні реалії та зарубіжний досвід для України. Матеріали I Щорічної міжнародної науково-практичної конференції (22 вересня 2016 року). (р. 130). Київ: Національна академія прокуратури України.

16. Комаров С.А. (1998) Общая теория государства и права. (pp. 81). Москва: Юрайт

17. Лібанова Е.M. (Ed) Соціально-економічний потенціал сталого розвитку України та іiі районів (2014) Національна доповідь. (рp. 108) Київ:ДУ “ІЕПСР НАН України”.

18. Орзіх М.П. (1995) Концепція правового статусу самоврядних територій і органів місцевого самоврядування. Місцеве та регіональне самоврядування України, № 1, 67.

19. Перчеклій I.M. (2015) Право власності українського народу на природні ресурси: еколого-правові засади. Автореферат дисертації на здобуття наукового ступеня кандидата юридичних наук за спеціальністю 12.00.06 - земельне право; аграрне право; екологічне право; природоресурсне право. (рp. 11) Київ.;

20. Скакун О.Ф. (2001) Теорія держави і права. (рp. 39) - Харків: Консум

21. Спасибо-Фатєєва I.B. (Ed) Цивільний кодекс України: Науковопрактичний коментар. Пояснення, тлумачення, рекомендації 3 використанням позицій вищих судових інстанцій, міністерства юстиції, науковців, фахівців (2011) Том. 5. (рр. 42). Харків: ФОП Лисяк Л.С.

22. Шульга М.В, Устименко В.А. (2019) Землі як об’єкт земельних відносин: матеріали Всеукраїнської науково-практичної конференції (29 листопада 2019 р., м. Київ). Об’єкти екологічного і суміжних галузей права: теоретичні та практичні аспекти в умовах сталого розвитку. (pp. 67) Київ: НАН України. Ін-т економіко-правових досліджень.

\section{Information about the author:} Olena Borschevska, $\mathrm{PhD}$, Associate Professor at the Department of Civil and Labor Law, Odessa National Maritime University 34, Mechnikov str., Odessa, 65029, Ukraine ORCID ID: orcid.org/0000-0003-2549-429X 


\section{CONSTITUTIONAL DEVELOPMENT OF MODERN UKRAINE: WANDERING IN A CIRCLE? SOME ISSUES OF THE CONSTITUTIONAL SYSTEM FUNCTIONING}

\section{Olena Boryslavska}

\section{INTRODUCTION}

Constitutional development of modern Ukraine (after the proclamation of its state sovereignty) can hardly be called simple, linear, unambiguous and clearly progressive. Rather, it resembles wandering in a circle, which is reflected in the title of this section. In the text below, we will try to prove that this is the case, but, most importantly, we will find out the causes of this situation, identify the key problems and model the directions of their solution.

First of all, it is necessary to find out what is meant by the constitutional development of Ukraine. Today's legal science is dominated by two approaches to understanding this concept, which stem from the positivist and the naturalist types of legal thinking. The former one was more widespread in the Soviet era of legal science and assumes that constitutional development means any changes in the state-legal existence reflected in the constitutional text. The nature of such changes, their focus (whether it is centralization of power, protection of human rights or other goals) or whether they are regarded as minor are not taken into account. In other words, constitutional development is in fact synonymous with "political system development"1, "state development"2, accompanied by appropriate constitutional reforms, or "constitutional process"3.

The naturalist approach to understanding constitutional and legal phenomena stems from the original idea of the essence of constitution and its value as an effective means of guaranteeing individual freedom, fundamental human rights and freedom of civil society through the imposition of restrictions on state power, as well as state arbitrary and tyranny prevention ${ }^{4}$.

1 Rozumnyj M. (2008) Rozvytok politychnoi systemy Ukrainy: vyklyky i zahrozy. [Development of Ukraine's Political System: Challenges and Threats] Politychnyi menedzhment, № 1, pp. 9-13.

${ }_{2}$ Tatsii V.Ya. (2014) Aktualni pytannia konstytutsiinoi reformy ta derzhavnoho rozvytku na suchasnomu etapi [Current Issues of Constitutional Reform and State Development at the Present Stage] Pravo Ukrainy, 2014, № 7, pp. 10-18.

${ }^{3}$ Shemshuchenko Yu. S. (2014) Konstytutsiinyi protses u nezalezhnii Ukraini [Constitutional Process in the Independent Ukraine] Pravo Ukrainy, 2014, № 7, pp. 19-24.

${ }^{4}$ More about this: Boryslavska O.M. (2014) Metodolohichni pidkhody do rozuminnia sutnosti konstytutsionalizmu [Methodological Challenges Of Understanding The Essence Of Constitutionalism] Naukovyi visnyk Khersonskoho derzhavnoho universytetu, 2014, Issue 6-1, Vol. 1, pp. 70-74. 
Therefore, the constitutional development of the state (including Ukraine) does not include all changes in state and legal systems which interfere with the text of the constitution, but only those aimed at implementing the key idea of constitution and constitutionalism, respectively.

We proceed from this approach and consider constitutionalism not as a purely theoretical construction, but as a practical model of the political system functioning ${ }^{5}$. Therefore, under the constitutional development of modern Ukraine we mean a movement aimed at forming a constitutionally restricted government and creating a constitutional system, the purpose of which is to guarantee individual freedom and fundamental human rights. Accordingly, the progressive development (as stated at the beginning of the section) can only be viewed as the one aimed at achieving the stated goals, which in itself is not easy. In the Ukrainian realities, this process is even more complicated because it occurs with the simultaneous establishment of Ukrainian statehood, the struggle for state sovereignty and territorial integrity of Ukraine.

\section{Features and key issues of the constitutional development of Ukraine}

As already stated, in view of the constitutional development of Ukraine, we mean its formation as a constitutional state. The famous British scientist Albert Dicey divided states into constitutional and unconstitutional in the late 19th century $^{6}$. The analysis of the contemporary political and legal organization of the modern states in the world leads to the conclusion that today, in the political sense, the world is in fact divided into three camps: constitutional states in which state power is limited to guarantee individual fundamental rights (approximately one fourth of all states in the world), unconstitutional states with arbitrary power (about the same number), and transitional states (transit from arbitrary to constitutionally restricted government (about half of the states in the world). Constitutionalism is the ideological and doctrinal basis of the functioning of constitutional and transitional states, but while the former managed to put it into practice, the latter are only in the process of forming constitutionally restricted governments. The latter include Ukraine, which, having proclaimed independence, made its civilizational choice and in fact took the path of forming a constitutional state.

Starting from the first political and legal documents that proclaimed state sovereignty and ending with the 1996 Constitution, Ukraine was gradually

${ }^{5}$ More about this: Boryslavska O.M. (2018) Yevropeiska model konstytutsionalizmu: systemno-aksiolohichnyi analiz [European model of constitutionalism: a system-axiological analysis] Kharkiv: Pravo, 2018.

${ }^{6}$ Dicey A. V. (1982) Introduction to the Study of the Law of the Constitution. Indianapolis: Liberty Classics, 1982. pp. 110-117. 
adopting a liberal-democratic ideology, which was to form the basis of this process (now it is reflected in the Basic Law).

However, the constitutional development of Ukraine cannot be called linear and progressive all the time. This, in particular, is evidenced by serious problems of the constitutional system of government: 1) repeated change of forms of government (1996, 2004, 2010, 2014); 2) questionable, in terms of legitimacy, the Constitution amending procedure (2004, 2010, 2014); 3 ) concentration of powers by the Head of State (2010-2013, 2019-2020); 4) crises in the Constitutional Court activities (2005-2006, 2016-2017).

Moreover, some of the listed problems were repeated with some cyclicality. For example, the mixed form of government, which was included in the 1996 Constitution, drifted towards the strengthening of the presidential power (2010), and then its formal weakening (2004, 2014). Constitutional amendments, the procedure for which is clearly set out in Section XIII of the Constitution, were introduced in violation in 2004, 2010 and 2014. In addition, regardless of the formally determined constitutional powers of the Head of State, the presidential power has been excessively concentrated during 2010-2013, a similar situation is observed today (2019-2020), etc.

Such a recurrence of the same mistakes in the development of Ukraine gives grounds to speak about the effect of "wandering in a circle", which is opposite to the linear and progressive constitutional development of the state. Leaving this circle requires first of all understanding the essence of the current situation, finding out the causes of the existing problems and modelling their solutions. Since some of these issues have been the subject of separate publications, here we will focus on some of them.

\subsection{Form of the government and power concentration by the Head of the state}

Limitations of state power and prevention of state arbitrariness are directly related to the chosen option of separation of state power and form of government, respectively. With the adoption of the 1996 Constitution, Ukraine has chosen a mixed form of government, but it periodically fluctuates between its so-called "presidential-parliamentary" and "parliamentarypresidential" models. In this case, the fact that the content of the government (constitutional, internally restricted) rather than its form, as well as balance of the public power system, are much more valuable, is out of sight.

The fundamental idea of the separation of powers in a constitutional state is to limit state power in order to guarantee human rights and freedoms, prevent usurpation, excessive concentration and, accordingly, state arbitrariness. Therefore, the principle of separation of powers is the basis of the institutional design of a constitutional state. Having been reasoned by John 
Locke $^{7}$, James Harrington ${ }^{8}$, Charles-Louis Montesquieu, the idea of separation of powers has been evolving and developing, taking into account the peculiarities of social development. However, its focus on preventing arbitrariness through the establishment of legal restrictions on state power remained unchanged. As Montesquieu assumed, every person with power is inclined to abuse it and tries to exercise their authority for as long as possible. Therefore, it must be restrained by an appropriate organizational structure of state power, under which the legislative and executive powers cannot be united in one person or institution (otherwise there will be no possibility for guaranteeing freedom), and the judicial power must necessarily be separated from the power of the legislative and executive ${ }^{9}$.

In the modern interpretation, the concept of separation of state power mainly covers the following elements: 1) power is divided into three branches - legislative, executive, and judicial with a corresponding function of each of them; 2) each branch of government must be restricted in performing its function and should not interfere with the functions of other branches of state power; 3) the persons who make up the bodies of these branches of power must be separated from other branches of government and cannot simultaneously perform their functions. If these requirements are met, then each branch of government will act as a fuse for the arbitrariness of other branches of government ${ }^{10}$.

This doctrine is a kind of ideal model that has never been implemented into practice in such a "pure" form, but instead there are a number of options close to it. The practice of constitutional democracy is characterized by the existence of several successful options for the separation of powers, which are conditionally divided into rigid and flexible ones. This division is largely driven by the role of the president in the constitutional model of separation of powers.

The essence of the rigid model of state power separation, which was first successfully implemented in the United States of America, is to maximize the separation and autonomy of branches of state power, in which the president directly heads the executive, manages and, moreover, embodies it $^{11}$. In the

${ }^{7}$ Locke John (2009) Tsili politychnoho suspilstva ta vriaduvannia [Of the Ends of Political Society and Government]. O. Protsenko and V. Lisovyi. Liberalizm: Liberalna tradytsiia politychnoho myslennia vid Dzhona Lokka do Dzhona Roulza. Antolohiia. 2-he vydannia (pereroblene). Kyiv: Smoloskyp, 2009, pp. 638-643 (in Ukrainian).

8 Harrington James (1992) The Commonwealth of Oceana and A System of Politics. Cambridge University Press, 1992, pp. 206-208.

${ }^{9}$ Monteske Sh.L. (1999) O dukhe zakonov [The Spirit of Laws]. M: Mysl, 1999, pp. 137-139 (in Russian).

${ }^{10}$ Vile M.J.C. Constitutionalism and the Separation of Powers. 2nd ed., Indianapolis: Liberty Fund. 1998. P. 5-19.

${ }^{11}$ Howell William G., (2013) Thinking About the Presidency: The Primacy of Power, Princeton: Princeton University Press, 2013. 
United States, the system of separation of powers is constructed in such a way that branches of state power constantly compete with each other, thus restraining each other and forming a system of counterbalances ${ }^{12}$. Only a small number of modern constitutional systems is based on the rigid model of separation of powers (if to take into account constitutional states with a universally recognized high level of democracy and the rule of law, except for the United States - they are present only in Uruguay and Costa Rica).

The model of flexible separation of powers implies the interconnection and interdependence of the legislative and executive branches of state power; their limitation in a constitutional democracy is guaranteed by the constitutional jurisdiction (in Continental Europe) or an independent court (United Kingdom). In the United Kingdom, for example, the mechanism of division of the state power is based on the supremacy of the parliament, while the legislature and the executive work in tandem. Therefore, the key task of the court is to restrain parliamentary supremacy and to prevent the arbitrariness of the parliamentary majority, which, in addition to passing laws, forms the government and controls its activities. As regards repulics, in conditions of a flexible separation of state power, the President is primarily assigned the function of state representation, although he does not exclude the real powers in the sphere of executive power.

The model of a flexible separation of powers is also inherent in mixed forms of government (semi-presidential republics). They are characterised by such features of parliamentary form of government as a parliamentary way of forming a government, parliamentary accountability of the government, the dependence of parliamentary authority on the existence of a parliamentary majority (a formal feature - the president's right to dissolve the parliament in the absence of it) and others. The involvement of the president, more or less, into the formation of the government does not deny the dependence of this process on the parliament. Such a flexible model of separation of state power is implemented in Ukraine.

As a rule, in constitutional doctrine, "pure" forms of government are associated with the risks of usurpation of power or, at least, its excessive concentration by the heads of state in presidential republics or ruling parties and their leaders in parliamentary ones ${ }^{13}$. Indeed, there are many such examples in history and in modern political and legal practice. That is why,

${ }^{12}$ Kriner Douglas L. and Reeves Andrew (2015), The Particularistic President: Executive Branch Politics and Political Inequality, New York: Cambridge University Press, 2015, pp. 16.

13 Stacey Richard, Sujit Choudhry (2014) Semi-Presidential Government in the PostAuthoritarian Context. The Center for Constitutional Transitions Meeting the Challenges of Emerging Constitutional Democracy Working Paper Series, URL: https://ssrn.com/abstract= 3025979 
the introduction of mixed forms of government is seen as a method of avoiding the threats that pure forms potentially carry. Logically, in the conditions of constitutional democracy, they should neutralize the excessive powers of the parliamentary majority or the head of state.

Thus, according to Duverger, the mixed government is characterized by three distinctive features: 1) a popularly elected president; 2) the president has substantial constitutional authority; 3 ) there is also a cabinet of ministers and a prime minister dependent on the confidence of the parliamentary majority ${ }^{14}$. Accordingly, the dual influence on the formation of the government by the president and parliament, as well as the double responsibility of the government, are intended to balance the power of the president, the legislature and the executive, as well as to restrain them from excessive concentration of powers and related abuses.

However, the experience of modern states shows that such a scheme does not always work in practice. On the contrary, the mixed form of government creates a number of problems that Ukraine also faces. The most acute and widespread are potential conflict and the threat of over-concentration of power by the head of state and / or political party to which he belongs.

First of all, it should be noted that with a mixed form of government, presidential power may be even stronger than in a presidential republic, because, in addition to powers in the executive branch, the head of state has significant leverage over the legislative power (this, incidentally, can partly explain the existing commitment to this model in the post-Soviet states). Therefore, in conditions where the president has his own parliamentary majority, he gains virtually unlimited control over the executive branch, as well as serious levers of influence on other elements of the constitutional system (the bodies, the formation and / or appointment of leaders of which is shared between the president and parliament to balance it). And when the president and the parliamentary majority are representatives of opposing political forces (the so-called "coexistence" state), the chances of conflict of mixed forms of government are high.

The Constitution of Ukraine, in the wording of 1996, introduced a mixed form of government with the predominance of presidential power. Not only was the Head of State a representative of the state and the Supreme Commander-in-Chief, but he also had considerable serious powers in the sphere of executive power, as well as powers to influence the parliament (including its dissolution). Under different political circumstances, this form of government has manifested itself in different ways, but in the period

14 Duverger M. (1980) A new political-system model: semi-presidential government. European Journal of Political Research, № 8(2), pp. 165-187. 
2010-2013 it was reflected in the usurpation of power in the hands of President Yanukovych, whose political party had a majority in parliament.

Introduced by the constitution of Ukraine in the 2004 version, the mixed form of government with preference for parliamentary forms (as well as returning to it in 2014) solved this problem only at first glance and made it possible to achieve only a short-term goal - to partially limit the power of the head of state in specific political realities existing at that time. The mixed form of government is fundamentally dependent on existing political conditions, and its potential, as noted, provides for several options for implementation in practice.

During the period from 2005 to 2010, when the president and prime minister were representatives of different political parties, such a feature of the mixed form of government as conflict manifested itself quite clearly. A prime example of this is, in particular, the period of presidency of Viktor Yushchenko with Yulia Tymoshenko as Prime-minister, (2005, 2007-2010), when the President and the Prime-minister blocked each other's activities by using institutions of countersigning ${ }^{15}$, challenging legal acts to the Constitutional Court, early termination of powers, etc.

After the presidential and parliamentary elections in 2019 which led to the power of V. Zelensky and his political party, which gained the majority in the parliament, another negative feature of the mixed form of government emerged - the threat of concentration of powers by the head of state. Relying on a majority in the legislature, the President actually formed a government (although under the Constitution, these powers are vested in Parliament), replaced the Prosecutor General, the head of the Security Service of Ukraine, and heads of several other bodies of state power.

At the same time, the head of state introduced for consideration by the newly elected parliament (on the second day of its functioning) seven bills on amendments to the Constitution of Ukraine, which, if adopted, would in their totality lead to a significant strengthening of the presidential power (appointing heads of the State Bureau of Investigation, National Anti-corruption Bureau, introducing full discretion to create regulatory bodies ${ }^{16}$ etc.) and simultaneously

15 Kobryn V.S. (2016) Problemy praktychnoho funktsionuvannia instytutu kontrasyhnuvannia aktiv hlavy derzhavy v Ukraini [Problems of Practical Functioning of the Institute of Contraigning the Acts of the Head of State in Ukraine]. Visnyk Natsionalnoho universytetu “Lvivska politekhnika”. Yurydychni nauky, 2016, № 845, S. 200-205 (in Ukrainian).

${ }^{16}$ Draft on the Amending of the art. 106 of the Constitution of Ukraine № 1014 (29.08.2019) (on the establishing the powers of the President of Ukraine to form independent regulatory bodies, the National Anti-Corruption Bureau of Ukraine, appoint and dismiss the Director of the National Anti-Corruption Bureau of Ukraine and the Director of the State Bureau of Investigation) URL: https://w1.c1.rada.gov.ua/pls/zweb2/webproc4_1?pf3511=66250 (in Ukrainian) 
weakening the role of parliament (reducing the number of MPs in Ukraine ${ }^{17}$, expanding the list of grounds for early termination of powers of parliamentarians ${ }^{18}$ ). In addition, among the first laws passed, the Verkhovna Rada of Ukraine of the 9th convocation also adopted Law on Amendments to Article 80 of the Constitution of Ukraine concerning elimination of the People's Deputies of Ukraine inviolability ${ }^{19}$.

The next step was the introduction of a rather controversial draft of the bill on judicial reform, which foresees halving the number of judges of the newly formed Supreme Court (the mentioned bill caused a negative reaction not only of the legal experts, but also of the Council of Europe and the European Union bodies $^{20}$ ). All these legislative and constitutional initiatives were carried out against the backdrop of the first political steps of the newly elected head of state, including the dissolution of Parliament three months before the termination of his powers ${ }^{21}$.

It should be mentioned that a constitutional state with a mixed republican form of government can function successfully only if constitutional and administrative jurisdiction functions effectively and independently. It is them that guarantee the prevention of the arbitrariness of the President, the Parliament and the executive authorities. Those countries in which the constitutional and administrative jurisdictions are strong (for example, France) are less prone to excessive concentration of power by the head of state and the ruling party; in other cases, on the contrary. In Ukraine, unfortunately, constitutional and administrative jurisdictions do not constantly, independently and effectively, perform their functions of balancing the constitutional system, as will be discussed below.

\footnotetext{
${ }^{17}$ Draft Law No. 1017 of 29.08 .2019 on Amendments to art. 76 and 77 of the Constitution of Ukraine (concerning reducing the constitutional composition of the Verkhovna Rada of Ukraine and introducing a proportional electoral system) URL: https://w1.c1.rada.gov.ua/pls/zweb2/ webproc4_1?pf3511=66257

${ }^{18}$ Draft Law No. 1027 of 29.08 .2019 on Amendments to Article 81 of the Constitution of Ukraine (concerning additional grounds for early termination of the powers of the People's Deputy of Ukraine) URL: https://w1.c1.rada.gov.ua/pls/zweb2/webproc4_1?pf3511=66257

${ }^{19}$ Law of Ukraine No. 27-IX on Amendments to Article 80 of the Constitution of Ukraine (concerning inviolability of the People's Deputies of Ukraine) URL: https://zakon.rada.gov.ua/ laws/show/27-20

${ }^{20}$ Opinion On Amendments To The Legal Framework Governing The Supreme Court And Judicial Governance Bodies Adopted By The Venice Commission At Its 121st Plenary Session (Venice, 6-7 December 2019) URL: https://www.venice.coe.int/webforms/documents/?pdf=CDL$\mathrm{AD}(2019) 027-\mathrm{e}$

${ }^{21}$ On the early termination of powers of the Verkhovna Rada of Ukraine and the appointment of snap elections: Presidential Decree. \# 303/2019 of May 21, 2019 URL: https://zakon.rada.gov.ua/ laws/show/303/2019
} 


\subsection{Effective activity of the Constitutional Court and independence of the Judiciary}

The value of a Constitutional Court (or other body of constitutional jurisdiction) in a constitutional state is related to its functions. Thus, Constitutional courts not only decide on the unconstitutionality of legal acts and conduct the interpretation of the Constitution, the protection of constitutional rights and freedoms, which are the main areas of the constitutional jurisdiction activities, but also perform other functions important to ensure balance within the constitutional system, in particular, settle competencies and other disputes between the Federation and its subjects, election disputes, cases of bringing to justice the state officials, etc.

When it comes to states with mixed forms of government, to which Ukraine belongs, an important task of the Constitutional Courts (within their common mission to ensure constitutional democracy) is to prevent the arbitrariness of the president and parliament (parliamentary majority).

Therefore, the activities of the Constitutional jurisdiction bodies are related to the functioning of the mechanism of separation of state power, and the cases they resolve most often concern the higher bodies of state power and higher officials. That is why the effective exercise by the body of Constitutional Jurisdiction of its functions is possible only in the case of the guarantee and practical assurance of its independence and political neutrality, as well as its credibility as an independent arbitrator. Otherwise, the very existence of such an institution is devoid of content.

It was Hans Kelsen who was the first to consider the independence of the Constitutional Court as a necessary feature without which it could not carry out its functions. Analysing the Austrian reform of 1929, when the executive dissolved the composition of the Constitutional Court, formed by the Parliament and appointed new judges (who were its supporters), Kelsen noted, "It was the beginning of a political evolution that would inevitably lead to fascism and is responsible for the fact that Austria's annexation by the Nazis met with no resistance" 22 .

Coming back to the activities of the Ukrainian Constitutional Court, we should say that it can hardly be called unambiguously effective, and it takes its place in the constitutional system as a truly independent and politically impartial arbitrator. The periods of relative independence and efficiency were interrupted by 1) rather contradictory decisions, which called into question such impartiality (for example, the decision of the Constitutional Court on the

\footnotetext{
${ }^{22}$ Hans Kelsen (1942) Judicial Review of Legislation: A Comparative Study of the Austrian and the American Constitution, The Journal of Politics, № 4(2), p. 188.
} 
possibility of being elected to the third term of office of the President ${ }^{23}$ ), and 2) change in the Court's judicial position on the issue which it has already resolved, without any justification for such a change (for example, the decision of the Constitutional Court of 2008 on the possibility of membership of only parliamentary factions in the parliamentary coalition ${ }^{24}$ and a decision of 2019 authorizing individual membership in the coalition ${ }^{25}$ ).

In addition, the work of the Court was generally blocked for some periods. For example, from October 2005 to August 2006, the Verkhovna Rada of Ukraine did not initially appoint its own quota for the judges of the CCU and refused to take the oath of judges of the CCU (under the current legislation it was a condition for the commencement of powers of a judge). Therefore, due to incomplete composition the Court could not exercise its powers.

Moreover, in some cases, the Constitutional Court avoided resolving conflicts within the system of separation of powers, when it was expected to defend the principles of constitutional democracy, justifying it by formal provisions or by the doctrine of "political question". The latter holds that "some questions in their nature are fundamentally political, and not legal, and if a question is fundamentally political ... then the court will refuse to hear that case. It will claim that it doesn't have jurisdiction. And it will leave that question to some other aspect of the political process to settle out" ${ }^{\text {"26 }}$.

For example, during the political crisis in 2007 (referred to in this study above as the President-Prime Minister's fight-rivalry), the CCU declined to decide on the constitutionality of the Cabinet of Ministers of Ukraine decree approving the Ministry of the Interior Regulations (which was the very

${ }^{23}$ Judgment of the Constitutional Court of Ukraine No. 22-rp / 2003 December 25, 2003 in the case on the constitutional submissions of 53 and 47 people's deputies of Ukraine on the official interpretation of the provisions of part three of Article 103 of the Constitution of Ukraine (case concerning the term of office of the President of Ukraine) URL: https://zakon.rada.gov.ua/ laws/show/v022p710-03 (in Ukrainian)

${ }^{24}$ Judgment of the Constitutional Court of Ukraine No. 16-rp / 2008 of 17 September 2008 in the case of the constitutional submission of 105 People's Deputies of Ukraine on the official interpretation of the provisions of Articles 83, 7, 9 of the Constitution of Ukraine (the case of a coalition of deputy factions in the Verkhovna Rada of Ukraine) URL: https://zakon.rada.gov.ua/ laws/show/v016p710-08 (in Ukrainian)

${ }^{25}$ Judgment of the Constitutional Court of Ukraine No. 11-rp / 2010 of 6 April 2010 in the case on the constitutional submission of 68 people's deputies of Ukraine regarding the official interpretation of the provisions of part six of Article 83 of the Constitution of Ukraine, part four of Article 59 of the Verkhovna Rada of Ukraine Regulations direct participation in forming a coalition of parliamentary factions in the Verkhovna Rada of Ukraine URL: https://zakon.rada.gov.ua/laws/show/v011p710-10 (in Ukrainian)

${ }^{26}$ John E. Finn (2016). Civil Liberties and the Bill of Rights. The Teaching Company. Part I: Lecture 4: The Court and Constitutional Interpretation (p. 55). URL: https://www.thegreatcourses.com/ courses/civil-liberties-and-the-bill-of-rights.html 
important issue not only in political life but in the interpretation of the existing separation of powers system) ${ }^{27}$.

Another example of such a situation was the actual self-removal of the Constitutional Court of Ukraine from resolving the question of the constitutionality of the dissolution by the President of Ukraine of the Verkhovna Rada of the VIII convocation. Thus, it was stated in the decision of the Constitutional Court of Ukraine that the people should resolve the said constitutional conflict by holding early parliamentary elections ${ }^{28}$.

All this has led, on the one hand, to a feeling of uncertainty that the Constitutional Court will be able to effectively resist attempts to usurp power or to prevent state arbitrariness, and, on the other hand, to very scrupulous public attention to the body of Constitutional Jurisdiction activities and to every decision it takes. This, in turn, has provoked the problem of the dependence of the Constitutional Court on public opinion, which is quite skilfully formed by politicians. As Professor Dieter Grimm rightly remarked, "The existence of a constitutional court alone, however, is not sufficient to guarantee that politicians respect the constitution. Just as constitutionalism is an endangered achievement constitutional adjudication is in danger as well. Politicians, even if they originally agreed to establish judicial review, soon find out that its exercise by constitutional courts is often burdensome for them. Constitutions put politics under constraints and constitutional courts exist in order to enforce these constraints" 29 .

Therefore, an important task for today is to ensure the real independence of the Constitutional Court of Ukraine and its impartiality in the exercise of powers. It is worth noting that the judicial reform of 2016 already envisaged changes that would have a positive impact on the status of the Constitutional Court of Ukraine and its independence. It concerns, in particular, the introduction of competitive bases for the selection of candidates for the posts of judges of the Constitutional Court. However, the legislative procedures aimed at implementing these principles need serious improvement. The low level of authority of the Constitutional Court of Ukraine as a result of its ambiguous activity over many years is one of the greatest obstacles to the

\footnotetext{
${ }^{27}$ Judgment of the Constitutional Court of Ukraine No. 20-y / 2007 of 28 March 2007 URL: http://www.ccu.gov.ua/docs/1150 (in Ukrainian)

${ }^{28}$ Judgment of the Constitutional Court of Ukraine No. 6-p / 2019 of 20 June 2019 in the case on the constitutional submission of 68 people's deputies of Ukraine concerning the conformity of the Constitution of Ukraine (constitutionality) with the Decree of the President of Ukraine "On early termination of powers of the Verkhovna Rada of Ukraine and the appointment of early elections" URL: http://ccu.gov.ua/docs/2770 (in Ukrainian)

29 Dieter Grimm (2011) Constitutional Adjudication and Constitutional Interpretation: between law and politics, NUJS Law Review, № 4(1), pp. 15-29.
} 
development of constitutional statehood, since a number of adopted acts are still often interpreted not as protection of the supremacy of the Constitution and its values but as certain political interests.

Real independence is also necessary for the entire judicial system, which is an important element of the constitutional system of government. It performs the functions of protecting human rights and freedoms, as well as exercising control over the legality and constitutionality of the activities of public authorities and, therefore, guaranteeing the system of separation of state power as a whole. Ultimately, the balance between freedoms and human rights, the interests of society and the responsibilities of the state is achieved through the activities of the judiciary.

The judiciary can only perform these functions holding its independence, which should be the primary task of the on-going judicial reform. Taking into account the experience of Post-socialist states that have undergone such changes, special attention should be paid to preventing further dependence of the judiciary (from executive bodies conducting various reviews of the judges and their "relevance to the position of a judge", prosecutors, other law enforcement agencies, the parliament and political parties).

\section{Reasons for the existing Ukrainian constitutional development problems and measures for solving them}

Analysing the problems of constitutional development of Ukraine and its constitutional system, it is important to find out their causes.

Apparently, there are many reasons that can be divided into two groups: 1) the reasons inherent in post-socialist states (most of such states have similar problems with the separation of powers, the independence of the court, and the activity of constitutional jurisdiction); 2) those that are specific to Ukraine (its geopolitical position, struggle for independence, territorial integrity, causes of historical and national-cultural character, etc.). Both of them should be considered and developed, and ways to solve them should be found.

An analysis of the constitutional development of Eastern European countries with many years of socialist experience shows that the problems described above are not unique to Ukraine. Of course, Western states that have deep constitutional traditions and extensive experience in the functioning of constitutional systems, developed peculiar tools for preventing the usurpation of power, as well as means and mechanisms for overcoming the constitutional and political conflicts. In contrast, the post-socialist states had to not only reform their public systems at the end of the 20th century, but also to change the ideology, as well as improve legal consciousness and constitutional culture, which are important conditions for its implementation in practice. 
In general, post-socialist states have a number of common problems with the functioning of the constitutional systems of government. First of all, there are difficulties in implementing the principle of separation of state power, which sometimes gets a kind of "skew" in one direction or another.

In Romania, for example, which has a mixed form of government, there are ongoing conflicts between the head of state and the head of executive power. Naturally, it is the case for the Constitutional Court to resolve such disputes, however, it himself became an object of political influence. Political pressure on the constitutional jurisdiction bodies is the most widespread and at the same time serious problem of this group of states, as well as issue of guaranteeing the independence of the judiciary (Romania, Hungary, Poland).

The mentioned problems in post-socialist states and their homogeneity show that the functioning of a constitutional state requires not only the transfer of elaborated options of the separation of powers to the national soil, but also the implementation of other elements of constitutional democracy, especially the ideology of constitutionalism.

The ideology of constitutionalism is perceived at the levels of legal consciousness and legal culture, which is also important for the functioning of the constitutional system of government. The absence of a sense of constitutional limitation in the heads of state, the heads of governments, and representatives of the parliamentary majority inevitably leads to an imbalance in the constitutional system and the crisis of constitutionalism. All these problems are inherent to Ukraine as well.

In addition to the problems common to the former countries of the socialist camp, Ukraine also has its own special ones that complicate its constitutional development. The most important of them, as we consider, are the lack of a single and unchallenged state-national identity reflected in constitutional identity, difficult geopolitical situation related to voluntary abandonment of nuclear weapons, and problems of protection of state sovereignty and territorial integrity of Ukraine from armed aggression. Ukraine is still in search of its own national identity, which is often interpreted differently by political elites that come to power.

Constitutional identity, based on the national identity of the state, is quite important for the functioning of the constitutional state. It should be noted that all constitutional European states that emerged in the late 18th and early 19the centuries were national states. Of course, their later development was linked to European integration and the formation of the common European identity, but the grounds of their constitutional statehoods were national. Ukraine has its own rather complicated history, which reflected in strong national traditions in the one hand and their denial on the other. Is Ukraine a national or multinational state? This basic for resolving many important issues is still 
questionable. Since the Ukrainian Constitution and related provisions leave a wide scope for their interpretation, from time to time we return to the complicated issues of the official language, special statues for some state entities and so on. The time so needed to build a strong and effective constitutional system is being wasted.

The same situation is with the geopolitical situation, on-going struggle for the territorial integrity and independence of Ukraine. All these problems are interrelated and related to the previous one. Resolving them takes too much time and effort, which could give significant results if used appropriately.

\section{CONCLUSIONS}

Constitutional development of Ukraine, aimed at building the constitutional state with constitutionally limited government according to doctrine of constitutionalism, needs resolving a range of issues, researched in this text. Some of them lie on the surface, while others are deeper and more serious.

Thus, problems of the constitutional system, such as improving the form of the government, preventing the concentration of power by the Head of the state, and ensuring independence and effectiveness of the Constitutional court and Judiciary are only one part of the problem that needs to be resolved. Of course, arbitrariness of state power needs to be avoided, but this is part of a deeper issue of the perception of constitutionalism ideology by the Ukrainian society and political elites. Only understanding of all threats of unlimited government, which definitely leads to the decline of constitutionalism, violation of human rights and, quite often, loss of statehood, can create an appropriate basis for its implementation.

Awareness of the full range of problems, both common to post-socialist states and purely Ukrainian ones, is the first step in developing a strategy for the constitutional development of Ukraine, which is essential today. It should include ideological and institutional parts. The first one should give answers to important questions of the Ukrainian constitutional identity and become a reliable basis for the unchallenged state sovereignty. The other one should create an effective, constitutionally limited constitutional system aimed at guaranteeing of human rights and freedoms.

\section{SUMMARY}

The article is dedicated to the issues of constitutional development of Ukraine. It is stated that constitutional development does not mean every change of political, social or state character, but only the one aimed at building a Constitutional state (in the sense of state with constitutionally limited government according to doctrine of constitutionalism). The 
constitutional development of Ukraine is quite complex with repeatedly arising problems, which gives the grounds to call it "wandering in the circle". The most important issues researched in the article are related to the form of government applied and the system of separation of powers, as well as the functioning of constitutional jurisdiction and concentration of powers by the Head of state. The main reasons for this are divided into two groups: those common for post-socialist states and the ones inherent to Ukraine. The first group includes the problems of separation of powers, independence of the judiciary, and the effective activity of constitutional jurisdiction. The second one deals with lack of a single and unchallenged state-national identity reflected in constitutional identity, difficult geopolitical situation related to voluntary abandonment of nuclear weapons, and problems of protection of state sovereignty and territorial integrity of Ukraine from armed aggression.

\section{REFERENCES}

1. Rozumnyj M. (2008) Rozvytok politychnoi systemy Ukrainy: vyklyky i zahrozy. [Development of Ukraine's Political System: Challenges and Threats] Politychnyi menedzhment, № 1, pp. 9-13.

2. Tatsii V.Ya. (2014) Aktualni pytannia konstytutsiinoi reformy ta derzhavnoho rozvytku na suchasnomu etapi [Current Issues of Constitutional Reform and State Development at the Present Stage] Pravo Ukrainy, 2014, № 7 , pp. 10-18.

3. Shemshuchenko Yu.S. (2014) Konstytutsiinyi protses u nezalezhnii Ukraini [Constitutional Process in the Independent Ukraine] Pravo Ukrainy, 2014, № 7, pp. 19-24.

4. Boryslavska O.M. (2014) Metodolohichni pidkhody do rozuminnia sutnosti konstytutsionalizmu [Methodological Challenges Of Understanding The Essence Of Constitutionalism] Naukovyi visnyk Khersonskoho derzhavnoho universytetu, 2014, Issue 6-1, Vol. 1, pp. 70-74.

5. Boryslavska O.M. (2018) Yevropeiska model konstytutsionalizmu: systemno-aksiolohichnyi analiz [European model of constitutionalism: a system-axiological analysis] Kharkiv: Pravo, 2018.

6. Dicey A.V. (1982) Introduction to the Study of the Law of the Constitution. Indianapolis: Liberty Classics, 1982.

7. Locke John (2009) Tsili politychnoho suspilstva ta vriaduvannia [Of the Ends of Political Society and Government]. O. Protsenko and V. Lisovyi. Liberalizm: Liberalna tradytsiia politychnoho myslennia vid Dzhona Lokka do Dzhona Roulza. Antolohiia. 2-he vydannia (pereroblene). Kyiv: Smoloskyp, 2009, pp. 638-643 (in Ukrainian).

8. Harrington James (1992) The Commonwealth of Oceana and A System of Politics. Cambridge University Press, 1992. 
9. Montesk'e Sh.L. (1999) O dukhe zakonov [The Spirit of Laws]. M: Mysl, 1999 (in Russian).

10. Vile M.J.C. Constitutionalism and the Separation of Powers. $2^{\text {nd }}$ ed., Indianapolis: Liberty Fund. 1998.

11. Howell William G., (2013) Thinking About the Presidency: The Primacy of Power, Princeton: Princeton University Press, 2013.

12. Kriner Douglas L. and Reeves Andrew (2015), The Particularistic President: Executive Branch Politics and Political Inequality, New York: Cambridge University Press, 2015.

13. Stacey Richard, Sujit Choudhry (2014) Semi-Presidential Government in the Post-Authoritarian Context. The Center for Constitutional Transitions Meeting the Challenges of Emerging Constitutional Democracy Working Paper Series, URL: https://ssrn.com/abstract=3025979

14. Duverger M. (1980) A new political-system model: semi-presidential government. European Journal of Political Research, № 8(2), pp. 165-187.

15. Kobryn V.S. (2016) Problemy praktychnoho funktsionuvannia instytutu kontrasyhnuvannia aktiv hlavy derzhavy v Ukraini [Problems of Practical Functioning of the Institute of Contraigning the Acts of the Head of State in Ukraine]. Visnyk Natsionalnoho universytetu "Lvivska politekhnika". Yurydychni nauky, 2016, № 845, S. 200-205 (in Ukrainian).

16. Draft on the Amending of the art. 106 of the Constitution of Ukraine № 1014 (29.08.2019) (on the establishing the powers of the President of Ukraine to form independent regulatory bodies, the National Anti-Corruption Bureau of Ukraine, appoint and dismiss the Director of the National AntiCorruption Bureau of Ukraine and the Director of the State Bureau of Investigation) URL: https://w1.c1.rada.gov.ua/pls/zweb2/webproc4_1? pf3511=66250 (in Ukrainian).

17. Draft Law No. 1017 of 29.08 .2019 on Amendments to art. 76 and 77 of the Constitution of Ukraine (concerning reducing the constitutional composition of the Verkhovna Rada of Ukraine and introducing a proportional electoral system) URL: https://w1.c1.rada.gov.ua/pls/zweb2/ webproc4_1?pf3511=66257 (in Ukrainian).

18. Draft Law No. 1027 of 29.08 .2019 on Amendments to Article 81 of the Constitution of Ukraine (concerning additional grounds for early termination of the powers of the People's Deputy of Ukraine) URL: https://w1.c1.rada.gov.ua/pls/zweb2/webproc4_1?pf3511=66257 (in Ukrainian).

19. Law of Ukraine No. 27-IX on Amendments to Article 80 of the Constitution of Ukraine (concerning inviolability of the People's Deputies of Ukraine) URL: https://zakon.rada.gov.ua/laws/show/27-20 (in Ukrainian). 
20. Opinion On Amendments To The Legal Framework Governing The Supreme Court And Judicial Governance Bodies Adopted By The Venice Commission At Its 121st Plenary Session (Venice, 6-7 December 2019) URL: https://www.venice.coe.int/webforms/documents/?pdf=CDL-AD(2019)027-e (in Ukrainian).

21. On the early termination of powers of the Verkhovna Rada of Ukraine and the appointment of snap elections: Presidential Decree. \# 303/2019 of May 21, 2019 URL: https://zakon.rada.gov.ua/laws/show/303/2019 (in Ukrainian).

22. Hans Kelsen (1942) Judicial Review of Legislation: A Comparative Study of the Austrian and the American Constitution, The Journal of Politics, № 4(2), p. 188.

23. Judgment of the Constitutional Court of Ukraine No. 22-rp / 2003 December 25, 2003 in the case on the constitutional submissions of 53 and 47 people's deputies of Ukraine on the official interpretation of the provisions of part three of Article 103 of the Constitution of Ukraine (case concerning the term of office of the President of Ukraine) URL: https://zakon.rada.gov.ua/laws/show/v022p710-03 (in Ukrainian).

24. Judgment of the Constitutional Court of Ukraine No. 16-rp / 2008 of 17 September 2008 in the case of the constitutional submission of 105 People's Deputies of Ukraine on the official interpretation of the provisions of Articles 83, 7, 9 of the Constitution of Ukraine (the case of a coalition of deputy factions in the Verkhovna Rada of Ukraine) URL: https://zakon.rada.gov.ua/laws/show/v016p710-08 (in Ukrainian)

25. Judgment of the Constitutional Court of Ukraine No. 11-rp / 2010 of 6 April 2010 in the case on the constitutional submission of 68 people's deputies of Ukraine regarding the official interpretation of the provisions of part six of Article 83 of the Constitution of Ukraine, part four of Article 59 of the Verkhovna Rada of Ukraine Regulations direct participation in forming a coalition of parliamentary factions in the Verkhovna Rada of Ukraine URL: https://zakon.rada.gov.ua/laws/show/v011p710-10 (in Ukrainian)

26. John E. Finn (2016). Civil Liberties and the Bill of Rights. The Teaching Company. Part I: Lecture 4: The Court and Constitutional Interpretation (p. 55). URL: https://www.thegreatcourses.com/courses/civilliberties-and-the-bill-of-rights.html

27. Judgment of the Constitutional Court of Ukraine No. 20-y / 2007 of 28 March 2007 URL: http://www.ccu.gov.ua/docs/1150 (in Ukrainian)

28. Judgment of the Constitutional Court of Ukraine No. 6-p / 2019 of 20 June 2019 in the case on the constitutional submission of 68 people's deputies of Ukraine concerning the conformity of the Constitution of Ukraine (constitutionality) with the Decree of the President of Ukraine "On early 
termination of powers of the Verkhovna Rada of Ukraine and the appointment of early elections" URL: http://ccu.gov.ua/docs/2770 (in Ukrainian)

29. Dieter Grimm (2011) Constitutional Adjudication and Constitutional Interpretation: between law and politics, NUJS Law Review, № 4(1), pp. 15-29.

\section{Information about the author:}

Olena Boryslavska,

Doctor of Juridical Sciences, Docent, Professor at the Constitutional Law Department, Ivan Franko National University of Lviv 1, Universytetska str., Lviv, 79000, Ukraine

ORCID orcid.org/0000-0001-8338-0966 Researcher ID https://publons.com/researcher/H-2177-2019/ 


\section{SPECIAL TECHNIQUE AS A CATEGORY OF LEGAL SCIENCE}

\section{Ivan Kharaberiush}

\section{INTRODUCTION}

Development of technical support of law enforcement is based on the achievements of science and technology, however, is directly dependent on social progress, the degree of understanding by the public of threats from crime, and therefore the need to develop and apply adequate measures to counter it.

The application of scientific and technical means has such a significant value in the prevention, disclosure and investigation of crimes today that it is conducting law enforcement was in most cases impossible. First of all it concerns the issues of collecting and securing evidence, obtaining operational information, expert studies, the implementation of preventive, procedural and investigative actions that need detailed audiovisual documentation of events, and identify signs of illegal activity, inaccessible to ordinary human perception. In these cases, the application of scientific and technical means plays a crucial role, becoming the main instrument of combating crime.

In all areas of law enforcement are used and implemented advanced scientific and technological achievements. The continual growth of technical equipment of law enforcement bodies of Ukraine, the presence of law enforcement agencies that systematically use scientific achievements have led to the emergence of independent groups of technical means. They are grouped according to the main directions of the activities of law enforcement agencies (investigating, investigative, administrative and legal, security) ${ }^{1}$ and combined, we believe the common concept of "special equipment of law enforcement bodies".

However, in forensic science there are certain approaches to the classification of technology for the subjects of its use in law enforcement activities, namely the technical means of operational-investigative purpose are divided into operative equipment, special equipment, special means ${ }^{2}$. Further, the authors rightly point out the main difference from the operational forensic technology, which is not in the quality characteristics of technical means, and procedural and methodological aspects of its use.

1 Kharaberiush I.F. (2011) Protydija zlochynnosti zasobamy specialjnoji tekhniky: konceptualjnyj pidkhid [Combating crime by means of special vehicles: a conceptual approach]. Donecjk: Vyd-vo "Noulidzh", pp. 37-41. (in Ukrainian)

2 Pjaskovsjkyj V.V., Chornous Ju.M., Ishhenko A.V. ta in. (2015) Kryminalistyka: pidruchnyk [Forensics: a textbook]. K.: "Centr uchbovoji literatury", pp. 71-72. (in Ukrainian) 
The scientists also determined that the investigator, the Prosecutor or the court for the gathering and study of evidence use of weapons, means and methods that represent the achievements of natural and technical Sciences, forensic and operational techniques ${ }^{3}$. In this context, operational and forensic equipment are treated as separate divisions of jurisprudence.

Generally, the law enforcement technique, like any other object of scientific research, has a certain number of features, features, properties, and it is therefore natural in our legal science to determine the place and to clearly define this category. It is no secret that conceptual coherence is particularly important for jurisprudence, and without a developed conceptual apparatus through which the study of legal reality is deepened, one cannot count on the development of legal science.

\section{The concept of special equipment as a legal category}

The implementation of the new social policy and the construction of a rule of law in Ukraine, in turn, requires the modernization of the domestic legal system. On this basis, to ensure the effective activity of law enforcement agencies in combating crime in the context of today, an important issue is to conduct a scientific search for the solution of problems of the theory of law, and in our case, it is the definition of technology used in law enforcement as a scientific category, to our opinion, a separate discipline of legal science.

We support the view that tools, as a legal category, are tools for securing any activity and are of a general, cross-sectoral nature ${ }^{4}$. Accordingly, the technical means used in law enforcement as a separate kind of means should also be considered from these positions and refer to different branches of legal science.

Investigating the use of the term "technical means" and derivative phrases (scientific and technical means, special techniques, special technical means), we have found that they have such widespread use in scientific publications, legislative and regulatory acts that refer to the activities of dozens of ministries and agencies that perform completely different tasks that are not related to one another, that their use out of context (for example, for law enforcement) and without special comment loses all meaning.

To achieve the goal of our work, it is necessary to define the scientific concept of "forensic technology" as the most researched category, which gave impetus to the development of technical disciplines in other branches of legal

\footnotetext{
${ }^{3}$ Volobujev A.F., Danjshyn M.V., Ishhenko A.V. Kryminalistyka : pidruchnyk [Forensics: a textbook]. Kharkiv, p.113. (in Ukrainian)

${ }^{4}$ Olijnyk O.V. (2015) Administratyvno-pravovi zasoby zabezpechennja informacijnoji bezpeky [Administrative and legal means of ensuring information security]. Jurydychnyj visnyk, vol. 1(34), p. 66.
} 
science. In particular, the generalization of literature indicates that today more than 150 definitions of the concept of forensic science and forensic techniques have been proposed for about 70 variants of the system-structural structure of forensics ${ }^{5}$.

R.S. Belkin views forensic technology as a section of forensics that includes a system of scientific provisions and techniques, techniques and techniques developed to gather, investigate, and use evidence and other crime detection and prevention measures ${ }^{6}$. He emphasizes on the information approach and believes that it is not only the gathering of evidence, but also the accumulation and processing of information about the event being investigated, as well as the technical means and methods of crime detection and prevention.

Other authors at the present stage of the development of scientific and technical support for law enforcement activities determine that forensic technology is a section of forensics, which is a system of theoretical provisions formed by the results of the study of mechanisms of crime and their traces, which develops technical means, techniques and methods directed detection, recording, deletion and investigation of these traces for the purpose of detection, investigation and prevention of crimes ${ }^{7}$.

The development of forensic science has improved the concept of "forensic technology". On the one hand, this concept refers to the section of the science of forensic science, and on the other - the set of technical means used in criminal proceedings. As a section of science, forensic technology is a system of scientific provisions and recommendations that ensure the development of technical means (instruments, tools, devices and materials), as well as techniques and methods of their use for the purpose of investigating and preventing criminal offenses ${ }^{8}$. In addition, forensic technology is a separate section of the course "Forensics."

As part of forensic science, forensic technology consists not only of individual elements, that is, forensic theories, techniques, methods, teachings, etc., but also of particular branches of knowledge that form their own system ${ }^{9}$.

${ }^{5}$ Tkach Ju.D. (2004) Ponjattja i systemno-strukturna budova kryminalistyky [The concept and system-structural structure of forensics] (PhD Thesis), Odesa: Odessa State University of Internal Affairs.

${ }^{6}$ Belkin R.S. (2000) Kriminalisticheskaya entsiklopediya [Forensic Encyclopedia]. M.: Megatron XXI, p. 102. (in Russian)

7 Djomina K.E. (2017) Kriminalisticheskaja tehnika : uchebnik [Forensic Technology: Textbook]. M.: Juridicheskij institut MIIT, p. 9. (in Russian)

${ }^{8}$ Pjaskovsjkyj V.V., Chornous Ju.M., Ishhenko A.V. (2015) Kryminalistyka: pidruchnyk [Forensics: a textbook]. K.: "Centr uchbovoji literatury", p. 64. (in Ukrainian)

${ }^{9}$ Markusj V.O. Kryminalistyka: navchaljnyj posibnyk [Forensics: a textbook]. K.: Kondor, p. 53. (in Ukrainian) 
The system of forensic technology includes general provisions and specific fields (forensic photography and video recording, trasology, weapons science, habit, etc.), which are also ambiguously defined by scientists.

Having analyzed the scientific sources and opinions of a number of reputable researchers, we can say that forensic technology is a separate, independent part of forensics with its own system of scientific and technical provisions, principles and techniques, techniques and methods used to collect, process, investigating and providing forensic information for the purpose of investigating, detecting and preventing crimes. It has a special character in its purpose, which is manifested in the service of mainly criminal proceedings and is the main "supplier" of procedural information.

Another means of special purpose can be called operative technique. In our previous research ${ }^{10}$, we have shown that the category "operative technique", as an independent section of the theory of operational-search activity (OSA), has several meanings, such as: section science; the type of activity of the respective subjects in the use of operative and technical means for solving the problems of ARD and criminal process; section of the discipline "Special technique OSA".

Operational technology as a part of the theory of operational search activity and a component of the more general scientific concept of "special law enforcement equipment" has its own system, which includes general provisions and branches of operational technology (means of public information acquisition, means of secret information and means of providing operational search events).

True, we believe, is the opinion of P.P. Artemenko, defining the concepts of "operative technique" and "operative-technical means", emphasized that these means, by their direct purpose, purpose, constructive data, tactical features of use, personal normative regulation received "special" nature of use in the fight against crime. Together, these include specially designed or adapted to the specific needs of operational and search activities forensic, radio engineering, chemical, optical, phototechnical, sound recording and other scientific and technical means ${ }^{11}$.

We can state that forensic technology and operational technology have a special purpose and are correlated as equivalent independent parts of such sciences as forensic science and investigative activities, respectively.

${ }^{10}$ Kharaberjush I.F. (2017) Operatyvna tekhnika jak teoretyko-prykladna kateghorija operatyvno-rozshukovoji nauky [Operational technique as a theoretical and applied category of operative-search science]. Visnyk Mariupoljsjkogho derzhavnogho universytetu. Serija : Pravo, vol. 13. pp. 77-82.

${ }^{11}$ Artemenko P.P. (1988) Special'nye operativno-tehnicheskie sredstva: uchebnoe posobie [Special operational technical means: a training manual]. K., p. 4. (in Russian) 
Next, the scope of the concept of "special law enforcement equipment" needs to be clarified. To do this, we first conduct a semantic analysis of the essence and content of the term "special technique". It includes two components. Turning to the explanatory dictionaries, you can see that the concept of "special" means special, exclusively for something intended for, and also refers to a specific area of something inherent in any specialty ${ }^{12}$.

The term "technique" means, first, the totality of labor, tools, through which create something, secondly, the very machines, tools, devices, and, third, the set of knowledge, tools, methods, techniques used in any business ${ }^{13}$.

Thus, technology, on the one hand, is a set of means of activity created to carry out the processes of production and service of non-productive needs of society; on the other, the aggregate characteristic used to achieve the goal of skills, techniques and methods.

Contextual analysis of the essence and content of the term "special technique" makes it incorrect to use it out of context without defining the scope of this technique. In this case, belonging to "special" can be defined as a special design, technical capabilities and purpose of the device, device or device, yes, we believe, and special (specific) tactical methods of using these or other technical means, which were also emphasized by the authors mentioned above. In some cases, both the technical tool itself and the tactics of its application may be special.

With regard to "special law enforcement equipment" in its most general form, it refers to the totality of special techniques, tactics and methods of their effective lawful use in law enforcement activities.

To determine the scope of the concept, we apply the criterion selection method. Therefore, in order to define the scope of the concept of "special law enforcement equipment", it is necessary to select the criteria by which we will define it. From the relevant criteria in this case, we can distinguish the semantics of the phrase; system; structure; practical meaning; the similarity of the special equipment with the technique, the special equipment means with the scientific and technical means used in law enforcement activities.

We begin with a semantic analysis of the essence and content of the term "special technique", in which we first distinguish the meaning of the component element "technique". In this context, we agree that since any statutory requirement is expressed by means of a language (legal language) whose elementary structural unit is a word (term), it is important that the meaning and scope of such terms be clear to all subjects to whom it is

${ }^{12}$ Ozheghov S.Y. (1990) Slovarj russkogho jazyka [Dictionary of the Russian language]. M.: Rus. jaz., p. 753. (in Russian)

${ }^{13}$ Ozheghov S.Y. (1990) Slovarj russkogho jazyka [Dictionary of the Russian language]. M.: Rus. jaz., p. 795. (in Russian) 
addressed. legal prescription. One way to ensure the clarity of the statutory prescriptive and understandable intention of the legislator is to apply the legislative definitions in the texts of the relevant regulatory acts ${ }^{14}$.

The concept of "special technique" began to form in the second half of the twentieth century and related to the development of police science. Considering the use of technical means in law enforcement activities within the existing technical and legal support at the time, we can conclude that the authors have different approaches to the definition of the concept of "special technique". Some scientists narrowed it down to technical means only for operational and search purposes ${ }^{15}$, while others, recognizing this concept as generic, limited themselves only to technical means ${ }^{16}$, ignoring the methodology and tactics of their use, some of them, by defining special technology, took into account its components, but not enough, to our opinion, outlined the directions and forms of its use ${ }^{17}$ or did not take into account the structural changes that took place in the internal affairs bodies ${ }^{18}$.

The situation was no better by definition of the special techniques used in law enforcement, and in the recent works of scientists of Ukraine and other States.

R.V. Mukoida and A.O. Shelekhov define special equipment as the system hardware and relevant tactical techniques, which are applied by the bodies of internal Affairs in strict compliance with the law in the fight against crime, ensuring public order and perform other duties assigned to them. In this case, by technical means, they include: seven core classes: communication; alarms and industrial television; operational-technical means (tools unofficial photography and video recording, means of covert recording, search devices; night surveillance; special chemicals); reconnaissance and technical information protection; forensic engineering; information systems; means of individual

\footnotetext{
${ }^{14}$ Khvorostjankina A.V. Definiciji v zakonodavchykh tekstakh: pytannja teoriji [Definitions in legislative texts: questions of theory] Retrieved from : https://minjust.gov.ua/m/str_6669. Accessed (11.01.2020)

15 Bilenchuk P.D., Dubovyj O.P., Saltevsjkyj M.V., Tymoshenko P.Ju. (1998) Kryminalistyka: pidruchnyk dlja slukhachiv, ad'junktiv, vykladachiv vuziv systemy MVS Ukrajiny [Forensics: a textbook for students, adjuncts, teachers of higher education institutions of the Ministry of Internal Affairs of Ukraine]. K.: ATIKA, 416 p. (in Ukrainian)

${ }^{16}$ Levkov A.I., Anufriev P.M. (1979) Ispol'zovanie sredstv special'noj tehniki v rabote ugolovnogo rozyska: nauchno-prakticheskoe posobie [The use of special equipment in the criminal investigation: scientific and practical manual]. Omsk, 96 p. (in Russian)

${ }^{17}$ Dekshne V.I., Romanov A.P., Chekmarev Yu.V. (1986) Tehnicheskie sredstva i sistemy upravlenija $v$ organah vnutrennih del [Technical means and control systems in internal affairs bodies]. M., 82 p. (in Russian)

${ }_{18}$ Artemenko P.P., Voronin B.P., Voskresenskij G.M. (1982) Special'naja tehnika i ee primenenie: uchebnoe posobie [Special equipment and its application: study guide]. M., 348 p. (in Russian)
} 
protection and active defense ${ }^{19}$. We believe that such a definition does not take into account the latest achievements of science and clearly defines the classification of special equipment for activities of bodies of internal Affairs.

Some authors are not limited to the bodies of internal Affairs, and consider special equipment within all law enforcement agencies. They are under special equipment law enforcement understand the instruments, devices, equipment, machinery, chemicals and other man-made items (and their uses) that can be legitimately and effectively used when carrying out quickly-search actions, investigation, the maintenance of the regime in correctional institutions, law enforcement to prevent crime and solve crimes in cities and other settlements ${ }^{20}$.

Other scientists argue that special technique is a combination of technical tools and scientific methods to their legitimate use by authorized law enforcement officials with the aim of preventing and solving crimes, other offenses, criminals, detention of prisoners and persons suspected and accused of committing crimes ${ }^{21}$.

We see that the author considers the basic elements of the concept of "special technique of law enforcement"overburdened functional properties of these funds and open promising directions of improvement related to the emergence of new types of crimes.

The emergence of new types of crime in the information-communication sphere (the sphere of new information technologies) and the practical experience of combating these crimes has allowed us to include the means of special equipment specific anti - software and program-technical means ${ }^{22}$ that are fundamentally different from traditional media, classified as special.

Considering information support of fighting crime, we also saw the emergence of a very important means of collecting, stockpiling, storing, processing, searching and providing the necessary information - automated information retrieval systems and automated specialized systems ${ }^{23}$. They are

${ }^{19}$ Mukoida R.V., Shelekhov A.O. (2013) Specialjna tekhnika v orghanakh vnutrishnikh sprav [Special equipment in law enforcement agencies]. Odesa: ODUVS, p. 5. (in Ukrainian)

${ }^{20}$ Pudakov E.R., Japparov R. R. (2017) Special'naja tehnika pravoohranitel'nyh organov [Special law enforcement technique]. Ufa: Izd vo BIST (filial) OUP VO "ATiSO", p. 5. (in Russian)

${ }^{21}$ Bystrjakov, E.N., Savel'eva M.V., Smushkin A.B. (2018) Special'naja tehnika [Special equipment]. Moskva : JuSTICIJa, p. 10. (in Russian)

${ }^{22}$ Kharaberiush I.F., Macjuk V.Ya., Nekrasov V.A., Kharaberiush O.I. (2007) Vykorystannja operatyvno-tekhnichnykh zasobiv u protydiji zlochynam, shho vchynjajutjsja u sferi novykh informacijnykh tekhnologhij [Use of operational and technical means in combating crimes committed in the field of new information technologies]. K. : KNT, pp. 55-56. (in Ukrainian)

${ }^{23}$ Kharaberiush I.F. Specialjna tekhnika jak chynnyk vplyvu na stan operatyvnoji obstanovky terytoriji obslughovuvannja pidrozdilamy karnogho rozshuku [Special equipment as a factor in 
specific hardware and software systems that constitute, in our opinion, a separate group of special equipment under the generalizing term "automated systems".

On the basis of generalization of research results in the field of intelligence and intelligent systems ${ }^{24}$, we argue that this is a promising process of providing information systems that are being used to fight crime, the properties of intelligence: communication skills; analytical capabilities; ability to constantly learn; adaptability; ability to self-evaluation; creativity.

We believe that intelligent systems is a more advanced level of automated systems, which should also be a separate group of special equipment that can significantly enhance the effectiveness of law enforcement.

Paying attention to hardware the concept of "special equipment of law enforcement bodies", take a closer look at its methodological component, in which we have to determine the place of modern information technology.

Try to understand what is the essence of the phenomenon of "information technology" for law enforcement, what meaning they have, what areas most effectively use them to improve the law enforcement can be, and what is the prospect of the development of information technology in law enforcement.

The Basic principles of information society development in Ukraine for 2007-2015 stated that one of the main priorities of Ukraine is striving to build focused on the interests of the people, open to all and aimed at development of information society, which is based on the concepts and programs of Informatization, the creation of various information and communication technologies and the national information-analytical systems of different levels and functions.

We can also see that in the context of global integration and stiff international competition the main arena of collision and struggle to push and pull of national interests of States becomes an information space. Modern information technologies enable States to implement their own interests without using military force, to weaken or to cause significant harm to the competitive security of the state, which does not have an effective system of protection from the negative effects of information.

Among the objective factors contributing to the modification of the stereotypes of human activity is the computerization of all spheres of its activities and the permanent growth of the volumes of information, and this in

influencing the operational situation of the territory of service of units of criminal investigation department], Visnyk Lughansjkogho derzhavnogho universytetu vnutrishnikh sprav imeni E.O. Didorenka, vol. 2, no 2, pp, 150-151.

${ }^{24}$ Kharaberiush I.F. (2018) Intelektualjni systemy v pravookhoronnij dijaljnosti [Intellectual systems in law enforcement]. Visnyk Mariupoljsjkogho derzhavnogho universytetu. Serija : Pravo, vol. 16, no. 1, pp. 39-45. 
turn requires the use of professional law enforcement modern achievements of scientific and technological progress, one of which is information technology.

Considering the term "technology" in a broad sense, we mean a body of knowledge that can be used for the production of goods and services from economic resources. In the narrow sense is a set of methods of transformation of substance, energy and information in the process of production, handling and processing of materials, Assembly of finished products, quality control, management ${ }^{25}$. The term "technology" includes methods, techniques, modes of operation, sequence of operations and procedures, it is closely linked with the applicable tools, equipment, tools, materials used.

Any technology provides:

- the subject of labor (the technological impact, technological object),

- means of labour (technology),

media processing functions (worker, team, etc.),

- the level of technological development of society.

The term "information" means that, with respect to information ${ }^{26}$. Therefore, the "information technology"- technology that is designed and for information. The subject of labor information technology is information and information resources. Labour means in our case are the computer equipment and telecommunications, and in the future - the means of information processing and communication corresponding to the level of technological development of society. Media processing functions can be computer equipment and telecommunications, automated information systems or law enforcement officials.

Thus, information technology is a set of methods, techniques, processing methods, processing or transmission of information and information resources computing and telecommunications, automated information systems or directly by employees to obtain the necessary information of product, control or manage certain processes.

Information resources (objects of accounting) information systems of law enforcement are objectively combined set of information directly on persons, events (criminal and administrative offences), the extraordinary event, which accumulates in the process of business activities of law enforcement agencies in the volume, structure and manner determined by the tasks assigned to them in accordance with applicable law.

${ }^{25}$ Busel V.T. (2001) Velykyj tlumachnyj slovnyk suchasnoji ukrajinsjkoji movy [A great explanatory dictionary of modern Ukrainian]. K.: Irpenj: VTF "Perun", p. 1245. (in Ukrainian)

${ }^{26}$ Nechvolod L.I. (2007) Suchasnyj slovnyk inshomovnykh sliv [Modern dictionary of foreign words]. Kharkiv: TORGhSIN PLJuS, p. 270. (in Ukrainian) 
From the above we can define the term "special equipment of law enforcement bodies". A special technique of law enforcement agencies are the totality of special equipment and methods of their lawful use in order to perform the tasks of law enforcement. Special equipment according to this definition is technical, software, hardware and software, special devices, substances, automated and intelligent systems. Methodological basis of special techniques are scientifically based tactics, techniques, and information technology.

\section{System-structural structure of special equipment of law enforcement agencies}

Having defined the conceptual apparatus, consider a system-structure of the special equipment law enforcement as a scientific category according to the selected criteria.

The system is a set of qualitatively defined elements, between which there is a natural relationship or a relationship. Consistency is an objective property inherent in every physical object, phenomenon, event. Special equipment as a branch of knowledge represents the totality of knowledge, which in a certain sequence according to their importance, relationships and relationships.

Generalization of the accumulated in the process of historical development of scientific data is one of the primary stages of the development of science as a separate branch of knowledge, and its data in a logically sound system testifies to the independence and maturity of the science, the level of theoretical generalization as embodied in its subject phenomena of objective reality which are studied by this science. The system of any science is not determined by an arbitrary assignment of those or other questions in the same discipline, and by combining them on the basis of internal unity and objective relations. Like every science, the special equipment law enforcement has its own system, which has evolved over time and requires a clear definition with regard to the requirements of modernity.

We already know - the concept of "special equipment" is General and used legislative and normative acts regulating the activities of many ministries and departments. Similarly, the term "special equipment of law enforcement bodies"brings together all the technical tools that are used in law enforcement and studied the separate academic disciplines. We in our previous works ${ }^{27}$ and individual researchers in their studies ${ }^{28}$ the basis for the interdisciplinary division

27 Kharaberiush I.F. (2011) Protydija zlochynnosti zasobamy specialjnoji tekhniky: konceptualjnyj pidkhid [Combating crime by means of special vehicles: a conceptual approach]. Donecjk: Vyd-vo "Noulidzh", pp. 37-41. (in Ukrainian)

${ }_{28}$ Artemenko P.P., Voronin B.P., Voskresenskij G.M. (1982) Special'naja tehnika i ee primenenie: uchebnoe posobie [Special equipment and its application: study guide]. M., pp. 15-16. (in Russian) 
of special equipment used the professional orientation of its use - investigative, investigative, legal and administrative. This is because, firstly, there is a legal regulation of the use of technology in each of these areas law enforcement. Second, a scientific base on the theory and practice of using scientific-technical means. Thirdly, accumulated extensive practical experience in the use of technology that helped to create a methodological basis for use of these funds in each of the abovementioned areas of law enforcement.

The term "special equipment of law enforcement bodies", by analogy with the forensic technique of ${ }^{29}$ and surgical technique ${ }^{30}$, first, the section refers to such Sciences as criminology, investigative and administrative activity; secondly, as a set of special techniques and methods of their use in law enforcement; third, as an academic discipline "Special equipment of law enforcement bodies".

Special equipment law enforcement as an interdisciplinary field of legal science is a system of scientific statements and recommendations, creating conditions for the development of technical tools (forensic, technical, operational, organizational, security), and scientific methods, techniques and information technologies with the aim of combating crime by law enforcement.

In our opinion, the system of special equipment law enforcement should be elements, which include General provisions and the special techniques of law enforcement. General provisions should define the basic concepts, system, principles of usage, tasks of special equipment, the General characteristics of the special equipment, techniques and methods of their application, legal regulation at the decision of tasks of law enforcement.

Industry special equipment of law enforcement bodies, as we have already specified, should consist of the main directions of its use in law enforcement. On directions of use it can be considered in relation to investigative activities and forensic technology, investigative activities and operational equipment, administrative - organizational machinery.

In turn, funds special equipment, we believe, can be classified according to three criteria: direction of use; sources; purpose.

On directions of use of means of special equipment can be divided into tools forensic, operational, organizational and security equipment.

${ }^{29}$ Chaplynsjkyj K.O., Luskatov O.V., Pyrigh I.V., Pletenecj V.M., Chaplynsjka Ju.A. (2017) Kryminalistyka [Criminalistics]. Dnipro : Dniprop. derzh. un-tvnutr. sprav ; LiraLTD. (in Ukrainian)

${ }^{30}$ Kharaberjush I.F. (2017) Operatyvna tekhnika jak teoretyko-prykladna kateghorija operatyvno-rozshukovoji nauky [Operational technique as a theoretical and applied category of operative-search science]. Visnyk Mariupoljsjkogho derzhavnogho universytetu. Serija : Pravo, vol. 13. pp. 77-82. 
Regarding the sources of funds special techniques that are used in law enforcement activities can be divided into three large groups: General use (adapted) for General use with minor alterations (modified) and specially designed (unique).

On purpose funds special equipment can be considered, given their technical capabilities, which are used to implement forms of law enforcement, namely:

- judicial;

- pre-trial investigation;

- investigative;

- intelligence;

- counterintelligence;

- control and oversight;

- administrative, security.

By purpose, we believe they are divided into: means of fixing information; management tools (communications, language enhancement, systems for collecting, accumulating and analyzing information, etc.); technical means of protection; search engine; means of observation and control; specialty chemicals; special protection means; means and systems of silently obtaining information and traces of illegal activity, etc.

Based on the definition of "special law enforcement agencies" defined by us, and taking into account the explanations provided by scientists regarding the scientific and technical means used in the criminal process, - "a set of devices, devices, apparatus, tools and materials used in accordance with the law specially authorized individuals to achieve a scientifically sound result that would contribute to the protection of the rights and legitimate interests of participants in criminal proceedings, full and rapid disclosure of crimes and exposure of persons guilty of their commission" 31 we can correlate them. In this context, the terms "scientific and technical means" are synonymous with "means of special technology" - technical, software and software tools, special devices, substances, automated and intellectual systems that are included as a specific component of scientific and technical means.

\section{CONCLUSIONS}

Summing up, we can say that the special technique of law enforcement agencies are the totality of special equipment and methods of their lawful use

31 Punda O.O. (2002) Vykorystannja danykh, oderzhanykh v rezuljtati zastosuvannja naukovo-tekhnichnykh zasobiv, dlja dokazuvannja $\mathrm{v}$ kryminaljnomu procesi [Use of data obtained as a result of the use of scientific and technological means for proving in criminal proceedings] (PhD Thesis), K. 
in order to perform the tasks of law enforcement. The development of special techniques of law enforcement, as a component of scientific-technical means, based on the achievements of science and technology, however, is directly dependent on social progress, the degree of understanding by the public of threats from crime, and therefore the need to develop and apply adequate measures to counter it. In this process, the implemented social features special equipment, such as cognitive, creative, educational, promotional, etc. active To a certain extent for the development of scientific and technical support of law enforcement with an innovative activity that is expressed by the formula development - testing - implementation - practice.

Special equipment of law enforcement bodies is an interdisciplinary legal theory, the components of which are studied by such Sciences as criminal process and criminalistics, operational-search activity, administrative law and process. It is made up of General provisions and individual industries.

Industry special equipment of law enforcement agencies consist of the main directions of its use in law enforcement and are divided into criminalistic equipment, operational equipment and office equipment.

Funds for special equipment are classified according to three criteria: direction of use; sources; purpose. On directions of use of means of special equipment are divided into tools forensic, operational, organizational and security equipment. Regarding the sources of funds special techniques that are used in law enforcement activities, divided into three large groups: General use (adapted) for General use with minor alterations (modified) and specially designed (unique). According to the designation they are divided into: a means of recording information; means of organization of management (communication, speech amplification system of collection, accumulation and analysis of information); technical security equipment; search equipment; monitoring and control; special chemicals; special protection; and secret information and traces of illegal activity.

\section{SUMMARY}

The correlation of forensic technology and operational technology among themselves and with special The equipment of law enforcement agencies was investigated. It is shown that the constant growth of technical equipment of the law enforcement agencies of Ukraine and the presence of law enforcement structures led to the emergence of independent groups of technical means. It is emphasized that the forensic technique has a special character for its purpose, manifested in the maintenance of the main criminal process to obtain procedural information. It is proved that operational technology, as a section of the theory of operational-search activity and a component of the more general scientific concept of "special technology of law enforcement 
agencies", has its own system and correlates with the forensic technique as equivalent categories of legal science. The emergence of a very important means of collecting, accumulating, storing, processing, searching and providing the necessary information is shown - automated information retrieval systems, automated specialized systems and intelligent systems that make up a separate group of special equipment. It is proved that the methodological basis of special equipment is scientifically based tactical techniques, methods and information technology. Special equipment of law enforcement agencies as an interdisciplinary branch of legal science is a system of scientific regulations and recommendations, create conditions for the development of technical tools (forensic, operational, organizational, security), as well as scientifically based methods, techniques and information technology to counter crime law enforcement agencies. The system of special equipment of law enforcement agencies consists of elements that include general provisions and branches of special equipment of law enforcement agencies. Branches of special equipment of law enforcement agencies consist of the main directions of its use in law enforcement, namely: with respect to investigative activities - forensic technology, operational search activities operational technology, administrative activities - organizational technology. It is proved that the special technique of law enforcement and forensic technology are both common and particular, respectively.

\section{REFERENCES}

1. Kharaberiush I.F. (2011) Protydija zlochynnosti zasobamy specialjnoji tekhniky: konceptualjnyj pidkhid [Combating crime by means of special vehicles: a conceptual approach]. Donecjk: Vyd-vo "Noulidzh" (in Ukrainian)

2. Pjaskovsjkyj V.V., Chornous Yu.M., Ishhenko A.V. (2015) Kryminalistyka: pidruchnyk [Forensics: a textbook]. Kyiv : "Centr uchbovoji literatury", pp. 71-72. (in Ukrainian)

3. Volobujev A.F., Danjshyn M.V., Ishhenko A.V. Kryminalistyka : pidruchnyk [Forensics: a textbook]. Kharkiv, p. 113. (in Ukrainian)

4. Olijnyk O.V. (2015) Administratyvno-pravovi zasoby zabezpechennja informacijnoji bezpeky [Administrative and legal means of ensuring information security]. Jurydychnyj visnyk, vol. 1 (34), p. 66.

5. Tkach Ju.D. (2004) Ponjattja $i$ systemno-strukturna budova kryminalistyky [The concept and system-structural structure of forensics] (PhD Thesis), Odesa: Odessa State University of Internal Affairs.

6. Belkin R.S. (2000) Kriminalisticheskaya entsiklopediya [Forensic Encyclopedia]. Moskva: Megatron XXI, p. 102. (in Russian)

7. Djomina K.E. (2017) Kriminalisticheskaja tehnika : uchebnik [Forensic Technology: Textbook]. Moskva : Juridicheskij institut MIIT, p. 9. (in Russian) 
8. Markusj V.O. Kryminalistyka: navchaljnyj posibnyk [Forensics: a textbook]. Kyiv: Kondor, p. 53. (in Ukrainian)

9. Kharaberiush I.F. (2017) Operatyvna tekhnika jak teoretyko-prykladna kateghorija operatyvno-rozshukovoji nauky [Operational technique as a theoretical and applied category of operative-search science]. Visnyk Mariupoljsjkogho derzhavnogho universytetu. Serija : Pravo, vol. 13. pp. 77-82.

10. Artemenko P.P. (1988) Special'nye operativno-tehnicheskie sredstva: uchebnoe posobie [Special operational technical means: a training manual]. Kyiv. (in Russian)

11. Ozheghov S.Y. (1990) Slovarj russkogho jazblka [Dictionary of the Russian language]. M.: Rus. jaz., p. 753. (in Russian)

12. Khvorostjankina A.V. Definiciji v zakonodavchykh tekstakh: pytannja teoriji [Definitions in legislative texts: questions of theory] URL: : https://minjust.gov.ua/m/str_6669. Accessed (11.01.2020)

13. Bilenchuk P.D., Dubovyj O.P., Saltevsjkyj M.V., Tymoshenko P.Yu. (1998) Kryminalistyka: pidruchnyk dlja slukhachiv, ad'junktiv, vykladachiv vuziv systemy MVS Ukrajiny [Forensics: a textbook for students, adjuncts, teachers of higher education institutions of the Ministry of Internal Affairs of Ukraine]. Kyiv: ATIKA. (in Ukrainian)

14. Levkov A.I., Anufriev P.M. (1979) Ispol'zovanie sredstv special'noj tehniki $v$ rabote ugolovnogo rozyska: nauchno-prakticheskoe posobie [The use of special equipment in the criminal investigation: scientific and practical manual]. Omsk, 96 p. (in Russian)

15. Dekshne V.I., Romanov A.P., Chekmarev Yu.V. (1986) Tehnicheskie sredstva $i$ sistemy upravlenija $v$ organah vnutrennih del [Technical means and control systems in internal affairs bodies]. Moskva, 82 p. (in Russian)

16. Artemenko P.P., Voronin B.P., Voskresenskij G.M. (1982) Special'naja tehnika i ee primenenie: uchebnoe posobie [Special equipment and its application: study guide]. Moskva, 348 p. (in Russian)

17. Mukoida R.V., Shelekhov A.O. (2013) Specialjna tekhnika $v$ orghanakh vnutrishnikh sprav [Special equipment in law enforcement agencies]. Odesa: ODUVS. (in Ukrainian)

18. Pudakov E. R., Japparov R. R. (2017) Special'naja tehnika pravoohranitel'nyh organov [Special law enforcement technique]. Ufa : Izd vo BIST (filial) OUP VO “ATiSO”. (in Russian)

19. Bystrjakov, E.N., Savel'eva M.V., Smushkin A.B. (2018) Special'naja tehnika [Special equipment]. Moskva : JuSTICIJa, p. 10. (in Russian)

20. Kharaberiush I.F., Macjuk V.Ja., Nekrasov V.A., Kharaberiush O.I. (2007) Vykorystannja operatyvno-tekhnichnykh zasobiv $u$ protydiji zlochynam, shho vchynjajutjsja u sferi novykh informacijnykh tekhnologhij 
[Use of operational and technical means in combating crimes committed in the field of new information technologies]. Kyiv : KNT, pp. 55-56. (in Ukrainian)

21. Kharaberiush I.F. Specialjna tekhnika jak chynnyk vplyvu na stan operatyvnoji obstanovky terytoriji obslughovuvannja pidrozdilamy karnogho rozshuku [Special equipment as a factor in influencing the operational situation of the territory of service of units of criminal investigation department], Visnyk Lughansjkogho derzhavnogho universytetu vnutrishnikh sprav imeni E.O. Didorenka, vol 2, no 2, pp, 150-151.

22. Kharaberiush I.F. (2018) Intelektualjni systemy v pravookhoronnij dijaljnosti [Intellectual systems in law enforcement]. Visnyk Mariupoljsjkogho derzhavnogho universytetu. Serija : Pravo, vol. 16, no. 1, pp. 39-45.

23. Busel V.T. (2001) Velykyj tlumachnyj slovnyk suchasnoji ukrajinsjkoji movy [A great explanatory dictionary of modern Ukrainian]. Kyiv: Irpenj: VTF "Perun", p. 1245. (in Ukrainian)

24. Nechvolod L.I. (2007) Suchasnyj slovnyk inshomovnykh sliv [Modern dictionary of foreign words]. Kharkiv: TORGhSIN PLJuS, p. 270. (in Ukrainian)

25. Chaplynsjkyj K.O., Luskatov O.V., Pyrigh I.V., Pletenecj V.M., Chaplynsjka Ju.A. (2017) Kryminalistyka [Criminalistics]. Dnipro : Dniprop. derzh. un-tvnutr. sprav ; LiraLTD. (in Ukrainian)

26. Punda O.O. (2002) Vykorystannja danykh, oderzhanykh v rezuljtati zastosuvannja naukovo-tekhnichnykh zasobiv, dlja dokazuvannja v kryminaljnomu procesi [Use of data obtained as a result of the use of scientific and technological means for proving in criminal proceedings] $(\mathrm{PhD}$ Thesis), Kyiv.

Information about the author: Ivan Kharaberiush, Doctor of Law, Professor, Professor at the Department of Law and Public Administration, Mariupol State University 129a, Stroiteley pr., Mariupol, 87500, Ukraine ORCID ID: orcid.org/0000-0002-4968-5421 


\section{EUROPEAN STANDARDS FOR ACCESS TO PROFESSIONAL LEGAL ASSISTANCE AND ENFORCEMENT ISSUES IN UKRAINE}

\section{Oksana Krushnitska}

\section{INTRODUCTION}

In Part 1 of Art. 59 of the Constitution of Ukraine it is defined that everyone has the right to professional legal assistance, and in cases provided by law, this assistance is provided free of charge ${ }^{1}$. The possibility of receiving free assistance is an additional guarantee for access to justice for those who cannot afford to pay for legal services. Therefore, any free assistant programs should have grounds for providing public services.

Legal assistance is an integral part of any justice, both international and national. International legal documents do not provide specific grounds for providing free assistance but require that the decision-making procedures for providing free legal services be fair and effective.

There are fundamental differences between the member states of the Council of Europe in the paradigm, organization, and management of legal assistant systems. Regarding the paradigm of systems, the common goal in some states is to ensure universal access to legal services and justice, while in other states legal assistance can be provided only to those most in need.

Ensuring the realization of the right to free legal assistance, in accordance with the specific conditions for its providing, requires the implementation by the state of an effective legal and organizational mechanism based on European standards.

The study of professional legal assistance was given attention by such scholars as: O.A. Banchuk, O.M. Bandurka, T.V. Varfolomeyeva, M.S. Demkova, I.B. Koliushko, A.T. Komzyuk and others. The problems of organization of the Institute of free legal assistance (hereinafter - FLA) were investigated by many native scholars, in particular, Ye. Bova, R. Tytykalo, L. Tatsiy, M. Antonovych, A. Bogma, as well as foreign scholars: R. Smith, R. Cassin, M. Kiku, F. Reagan, but these studies are relevant today, as there are still many problems in this area.

The research methodology is based on a systematic scientific analysis of European standards for access to professional legal assistance and the problem of enforcement in Ukraine, in determining the effectiveness of the legal

\footnotetext{
${ }^{1}$ Constitution of Ukraine: Law of Ukraine of 06.28.1996 No. 254k/96-VR. Vidomosti of the Verkhovna Rada of Ukraine (VVR), 1996, No. 30, p. 141.
} 
regulation of this method of protection and the development of proposals of recommendations for further improvement and proper application in national legislation.

\section{Legal and regulatory framework of free legal asisstance in Ukraine}

According to the practice of the European Court of Human Rights, Art. 6 of the Convention for the Protection of Human Rights and Fundamental Freedoms, the need for legal assistance in the interests of justice should be determined based on:

- the severity of the charges and the severity of the possible punishment;

- the complexity of the legal and factual circumstances of the case;

- difficult life circumstances in which the person is ${ }^{2}$.

Most assistance programs are available to citizens of the respective country, EU citizens, as well as foreign citizens legally or illegally residing in that country.

On December 20, 2012, the United Nations General Assembly adopted the Principles and guidelines for access to legal assistance in the criminal justice system, which contains standards for the providing of free legal assistance. These principles invite states to implement and strengthen measures to provide effective legal assistance around the world.

The right to free assistance of a defender is expressly established in Article 6 of the European Convention for the Protection of Human Rights and in Article 14 of the International Covenant on Civil and Political Rights ${ }^{3}$.

The right to professional legal assistance belongs to the constitutional guarantees of human rights and freedoms and the constitutional guarantees of the administration of justice. It is no coincidence that among all kinds of legal assistance, the assistance of a lawyer is governed by the constitutional and international law, and the right to other types of legal assistance is enshrined at the level of legislation.

The right to professional legal assistance is one of the procedural guarantees that promotes the fair trial of the rights and legitimate interests of not only participants in the judiciary, but also of society and the state as a whole. The rule of law cannot exist without an independent and professional judiciary, and the latter cannot function without an organized and independent legal profession that has to deal with the case fairly and professionally. It is

\footnotetext{
${ }^{2}$ Convention for the Protection of Human Rights and Fundamental Freedoms of 04/04/1950. Convention by Law No. 475/97-VR of 07.17.97.

${ }^{3}$ International Covenant on Civil and Political Rights of 12.16.1966. The International Covenant was ratified by Decree of the Presidium of the Supreme Council of the Ukrainian SSR N 2148-VIII (2148-08) of 10.19.73.
} 
the institution of the Bar that should be a reliable support of the judicial authority and the judiciary. Such a thesis is confirmed by a number of international documents and legislation of EU countries ${ }^{4}$.

Securing the exclusive representation of another person by a lawyer in court is aimed at ensuring a high level of quality and efficiency in providing professional legal assistance and is one of the guarantees of everyone's right to a fair trial. The right to professional legal assistance is an integral part of the right to judicial protection (Article 55 of the Constitution). In its turn, the right to a fair trial is an element of the rule of law (Article 8 of the Constitution).

By establishing the exclusive right of the Bar to exercise its powers in court, the State undertakes a positive obligation to ensure the effective exercise of the right of each person to the professional legal assistance provided for in Art. 59 and 131-2 of the Constitution.

Assertion at the legislative level of the rights, duties, guarantees of advocacy, as well as the special procedure for holding to account for their violation, special procedure of access to the profession, the obligation of observance of the lawyer's secrecy and the advocate immunity are aimed at ensuring the proper implementation of the norms of the Constitution for ensuring the human rights and fundamental freedoms in the provision of professional legal assistance ${ }^{5}$.

The exclusive right of lawyers to exercise their functions of defense and representation in courts is consistent with the international practice of the leading states and promotes the formation of a legal profession with unitary standards and ethical rules. The repeal of the mentioned provisions of Art. 131-2 of the Constitution will significantly narrow the content of the human right to judicial protection and, consequently, violate the substance of the fundamental right of everyone to judicial protection and a fair trial.

The free legal assistance system (hereinafter referred to as FLA) is a relatively new state human rights institution that is gaining in popularity with the public. Today, the FLA team has numerous lawyers and attorneys across Ukraine who are actively working with citizens in need of legal assistance. Classical lawyers at one time perceived the emergence of this institution as unfavorable. They considered this fact inadmissible, because a new competitor will "cut off" their clients. However, the idea of free legal

\footnotetext{
${ }^{4}$ Forming of the free legal assistance system in Ukraine [Electronic source]. Available at: http://legalaid.gov.ua/ua/operatyvna-info/formuvannia-systemy.

${ }^{5}$ Forming of the free legal assistance system in Ukraine [Electronic source]. Available at: http://legalaid.gov.ua/ua/operatyvna-info/formuvannia-systemy.
} 
assistance, the strengthening of the system and further improvement of its work have been actively promoted in recent years ${ }^{6}$.

Recently, the category of people who are able to get free secondary legal assistance was significantly expanded. It includes combatants, internally displaced persons, children, as well as victims of family abuse or genderbased violence. The vast majority of FLA clients are low-income earners, i.e. no more than two subsistence wages.

The basic legal assistance includes the following types of legal services:

- providing legal information;

- providing legal advice and clarification;

- preparation of statements, complaints and other documents of a legal character (except documents of a procedural character);

- providing assistance in accessing a person to secondary legal assistance and mediation.

Free secondary legal assistance (hereinafter referred to as FSLA) means the creation of the equal opportunities for persons to access justice, and includes such types of legal services:

- defense against the prosecution;

- representation of interests of persons entitled to such assistance in courts, other state bodies, bodies of local self-government, before other persons;

- settling procedural documents.

In the case of providing free secondary legal assistance in civil proceedings, the costs of providing professional legal assistance are not subject to apportionment between the parties and are at state expenses. The issues of financing the legal assistance system are not governed by civil procedural law, and therefore, these state expenses are not included in legal costs in civil proceedings. The costs of litigants for professional legal assistance have substantive and procedural aspects.

In the material sense, the expenses on the professional legal assistance are the payment for legal services rendered, the amount and procedure of payment of which are determined by the terms of the legal assistance agreement. The freedom-of-contract doctrine gives the parties the opportunity to determine its terms (Article 627 of the Civil Code of Ukraine), in particular regarding the payment (part 1 of Article 632 of the Civil Code of Ukraine).

In Ukraine, there is an ambiguous situation of the participation of lawyers in the system of free legal assistance. Article 25 of the Law of Ukraine

${ }^{6}$ Issues of the decentralization process of service delivery in the united territorial communities: a collection of roundtable papers and abstracts, Kyiv, April 18, 2019 / under gen. ed. of R.V. Voitovych, P.V. Vorona. Kyiv, “ArtEk”, 2019. 217 p. 
"On Advocacy and Legal Practice" dated July 5, 2012, determines that lawyers are subjects of free legal assistance. However, the Law of Ukraine "On Free Legal Assistance" (paragraph 2 of Part 1 of Article 15) restricts the range of subjects providing secondary legal assistance free of charge only to lawyers included in the register of lawyers providing such assistance, and therefore does not take into account the person's convention right to choose a lawyer. In addition, own standards and rules for the work of lawyers in the system of free legal assistance, which compete with the Rules of Lawyers Ethics and the normative acts that regulate the lawyer's activity were created. This position of the state is contradictory since professional associations of lawyers are virtually deprived of the opportunity to influence the free legal assistance system, "public lawyers" significantly restrict the choice of lawyers for legal assistance, and lawyers outside this system cannot fulfill their important professional duty. All this leads to a decrease in the efficiency of providing legal assistance to lawyers and the loss of their independence as a self-governing professional institution.

It should be emphasized that free legal assistance is usually provided to representatives of vulnerable groups and individuals who, due to their personal circumstances, are unable to protect their own interests in the case. The European Court of Human Rights takes into account the education and social status of the applicant and evaluates them in light of the complexity of the case.

According to Article 59 of the Constitution of Ukraine, everyone has the right to professional legal assistance. In cases provided by law, this assistance is provided free of charge. Everyone is free to choose a defender of his or her rights ${ }^{7}$.

Initially, the right to free legal assistance to specific categories of citizens was established by separate legislative acts, including the law of Ukraine "On the status of war veterans, guarantees of their social protection" dated October 22, $1993^{8}$, "On refugees and persons in need of additional or temporary protection" July $8,2011^{9}$, "On the Protection of Childhood" April 26, 2001 ${ }^{10}$, and others.

However, a single act that would unify not only the subjective composition of persons entitled to professional legal assistance but also provide for mechanisms

\footnotetext{
${ }^{7}$ Constitution of Ukraine: Law of Ukraine of 06.28.1996 No. 254k/96-VR. Vidomosti of the Verkhovna Rada of Ukraine (VVR), 1996, No. 30, p. 141.

${ }^{8}$ About the status of war veterans, guarantees of their social protection: the Law of Ukraine of October 22, 1993. Vidomosti of the Verkhovna Rada of Ukraine (VVR), 1993, No. 45, p. 425.

${ }^{9}$ About the status of war veterans, guarantees of their social protection: the Law of Ukraine of October 22, 1993. Vidomosti of the Verkhovna Rada of Ukraine (VVR), 1993, No. 45, p. 425.

${ }^{10}$ On the protection of childhood: Law of Ukraine of April 26, 2001. Vidomosti of the Verkhovna Rada of Ukraine (VVR), 2001, No. 30, p. 142.
} 
for its implementation have not been adopted. Being a member of the international community, Ukraine constantly receives recommendations from leading organizations on the implementation of a free legal assistance system.

In 2005, the Parliamentary Assembly of the Council of Europe called on the Ukrainian authorities to improve access to justice by introducing a system of free legal assistance in accordance with the standards of the Council of Europe and the case-law of the European Court of Human Rights.

Already in 2011, the Parliamentary Assembly of the Council of Europe, in the context of reforming the national prosecutor's office, recommended the oversight function to replace the strengthening role of the Ombudsman and the introduction of a free legal assistance system.

The basic approach to determining the number of persons entitled to free secondary legal assistance was first identified in the Concept for the Formation of a Legal Assistance System in Ukraine, approved by Decree of the President of Ukraine on June 9, 2006 No. 509/2006. Thus, in subparagraph 3 of paragraph 2 of section III of this document, it is established that the human right to free secondary legal assistance should be determined taking into account justice and the level of material support of a person ${ }^{11}$.

The Law of Ukraine "On Free Legal Assistance" dated June 1, 2000 No. 1768-III determined the subjects of the right to free professional legal assistance $^{12}$.

In accordance with international obligations, the Law on Free Legal Assistance is in force in Ukraine, it regulates legal relations in the sphere of providing free legal assistance to the subjects of the right to free primary legal assistance and to the subjects of the right to free secondary legal assistance established by this Law. Article 1 of this law says that free legal assistance is legal assistance that is guaranteed by the state and is fully or partially provided at the expense of the State budget of Ukraine, local budgets and other sources.

All persons under the jurisdiction of Ukraine are entitled to free primary legal assistance in accordance with the Constitution of Ukraine and this Law. The subjects of the providing of free primary legal assistance in Ukraine are executive authorities, local government, individuals, legal entities of private law and specialized institutions.

The mechanism for dealing with citizens whose appeals are groundless is not established by the legislation. The employees of the center cannot refuse to accept the appeal, although they may know that there is no judicial perspective.

\footnotetext{
${ }^{11}$ On the Concept of the formation of a system of free legal assistance in Ukraine: Decree of the President of Ukraine of June 9, 2006 No. 509/2006.

${ }^{12}$ About free legal assistance: Law of Ukraine dated 02.06.2011 No. 3460-VI. Vidomosti of the Verkhovna Rada of Ukraine (VVR), 2011, No. 51, p. 577.
} 
The EU Council has also recognized early access to legal assistance by a lawyer as one of the key components of a long-term plan to strengthen and protect the rights of suspected criminal proceedings in all EU countries. When "states use the need test to determine the eligibility for legal assistance, they must provide persons, who are in urgent need of legal assistance and are in police departments, detention centers or courts, with the preliminary legal assistance until it becomes clear whether these persons are entitled to receive such assistance" ${ }^{\prime 13}$.

The problem of timely legal assistance to a detainee in Ukraine is exacerbated by the fact that in almost $23 \%$ of cases the actual detention time does not coincide with the time indicated in the detention protocol. Moreover, there is a tendency for violations of the right of access to legal assistance of a lawyer in the early stages of criminal proceedings. Thus, the number of cases where the actual detention time does not coincide with the time specified in the detention protocol has increased by $20 \%$ over the past year and the number of violations of the client's rights to a confidential meeting with a client has increased by $17 \%{ }^{14}$.

In this regard, it is necessary to direct the concerted efforts of all criminal justice entities to ensure the effective early access to a lawyer for any suspect or accused, as provided for by the legislation of Ukraine and ECtHR practice. In particular, a cardinal change in the attitude of detention authorities and investigators and prosecutors to their obligations, under which they should be interested in the presence of a lawyer in the pre-trial investigation is necessary to avoid both the recognition of the evidence obtained inadmissible in the future and possible responsibility for violation of the right of defense provided by Art. 374 of the Criminal Code of Ukraine. In addition, the introduction of a system of automatic detention in Ukraine could help to eradicate violations of a person's right to defense in the early stages of criminal proceedings.

At the same time, some provisions of the current legislation governing the right of a person to legal assistance require further improvement and alignment with international standards. Thus, according to Art. 17 of the Law, the Centers may not only appoint a lawyer providing free secondary legal assistance, but also apply for the removal of a lawyer from the register of lawyers providing free secondary legal assistance, on grounds of, inter alia, the improper fulfillment of obligations under the contract specifications.

${ }^{13}$ Legal assistance in Europe: minimum requirements under international law [Electronic source]. Available at: http://osf.to/legal-aid-standards.

${ }^{14}$ Forming of the free legal assistance system in Ukraine [Electronic source]. Available at: http://legalaid.gov.ua/ua/operatyvna-info/formuvannia-systemy. 
Some scholars are concerned that the wide range of Centers' powers, which may be established outside the Centers Regulations Act (paragraph 13 of Article 17 of the Law), makes it possible to suggest that public administration of the Bar may become unlimited. We believe that the enshrined legislative control of the state over the activities of lawyers should be recognized as the fulfillment of the obligation to ensure the implementation of the paragraph 3 of Art. 6 of the ECtHR. However, in order for such an intervention to be in line with European standards, it must meet the stated aim - to provide effective free legal assistance - while being minimal - only to the extent of the achievement of the stated aim.

A free secondary legal assistant is a type of state guarantee that creates equal opportunities for people to have access to justice. It includes legal services such as protection; representation of interests of persons entitled to free secondary legal assistance in courts, other state bodies, in local authorities against other persons; preparation of procedural documents ${ }^{15}$.

One of the drawbacks of this Law was that it provided for long stages of the entry into force of some of its provisions.

It is important that the document did not impose any restrictions on the subjects of the right to free primary legal assistance, while only a small number of persons received the right to free secondary legal assistance.

Only on January 1, 2013, the centers of free secondary legal assistance, as state institutions, began to provide free secondary professional legal assistance to persons:

- to whom administrative detention has been applied;

- to whom an administrative arrest has been applied;

- who, in accordance with the provisions of the criminal procedure law, are considered to be detained;

- in respect of who pretrial detention has been selected;

- in criminal proceedings in respect of who, in accordance with the provisions of the Criminal Procedure Code of Ukraine, a lawyer, a prosecutor, an investigating judge or a court are involved in the protection of a separate procedural action;

- sentenced to imprisonment, detention in a disciplinary battalion of servicemen or imprisonment.

Since July 2016, the number of persons entitled to free secondary legal assistance in civil and administrative cases has been significantly expanded. These include:

- persons under the jurisdiction of Ukraine, if the average monthly total income of their family is below the subsistence minimum, calculated and

${ }^{15}$ About free legal assistance: Law of Ukraine dated 02.06.2011 No. 3460-VI. Vidomosti of the Verkhovna Rada of Ukraine (VVR), 2011, No. 51, p. 577. 
approved in accordance with the Law of Ukraine "On the subsistence minimum" dated July $15,1999^{16}$ for persons belonging to the main social and demographic groups of the population;

- persons with disabilities who receive a pension or a benefit instead of a pension of less than two subsistence minimums for disabled persons;

- orphans, children deprived of parental care, who are in difficult life circumstances, or who have suffered because of military operations and armed conflicts;

- persons covered by the Law of Ukraine "On Refugees and Persons in Need of Additional or Temporary Protection" dated July 8, 2011, from the moment when the person submits the application for recognition as a refugee or the person in need of additional protection in Ukraine until the adoption of the final decision on the application, as well as foreigners and stateless persons detained in order to identify and ensure forced expulsion from the moment of detention;

- war veterans and persons covered by the Law of Ukraine "On the status of war veterans, guarantees of their social protection" dated October 22, 1993, persons with special merits and special labor merits to their homeland, as well as those who became victims of Nazi persecution, on issues related to their social protection;

- persons in respect of whom the court is considering a case of limiting the civil legal capacity of an individual, declaring him legally incompetent, and the resumption of the civil legal capacity of an individual;

- persons in respect of whom the court is considering the case of the providing of psychiatric care in a forced manner;

- persons rehabilitated in accordance with the legislation of Ukraine on issues related to rehabilitation.

It is necessary to highlight some of the achievements of these innovations:

1) the legislator did not limit the guarantee of the providing of free secondary professional legal assistance only to citizens of Ukraine, extending it to persons who are under the jurisdiction of Ukraine;

2) victims of criminal offenses can now use the right to free professional legal assistance;

3) elimination of the requirement for low financial support for children in difficult life circumstances to receive free secondary professional legal assistance.

\footnotetext{
${ }^{16}$ On the living wage: Law of Ukraine of July 15, 1999. Vidomosti of the Verkhovna Rada of Ukraine (VVR), 1999, No. 38, p. 348.
} 


\section{Problematic aspects and possible ways to improve the professional legal assistance}

However, some weaknesses in these legislative changes can be highlighted. They should be analyzed in more detail:

1. The problem of determining the composition of the family to confirm the need for poverty as a qualifying requirement for secondary legal assistance.

The legal conflict arose because of the unequal determination of the composition of the family in order to assign the subject the right to free secondary legal assistance as a member of a poor family. According to Part 2 of Art. 3 of the Family Code of Ukraine, a family is formed by cohabiting individuals who are connected by a common life, and have mutual rights and obligations ${ }^{17}$.

Meanwhile, in paragraph 3 of part 2 of Art. 4 of the Law of Ukraine "On state assistance to low-income families" dated June 1, 2000 it is determined that the family includes husband, wife; relatives, adopted children of these persons under the age of 18 , as well as children who study full-time in general, vocational and higher educational institutions of I-IV levels of accreditation up to the age of 23 and do not have their own families; unmarried adult children who are recognized as disabled since childhood of groups I and II or as group I disabled and living with their parents; incapacitated parents and spouses who live with them and are dependent on them due to the lack of their own income; a person living with a lonely disabled person of group I and provides care for him; a woman and a man who lives in the same family, are not married, but have children in common ${ }^{18}$.

That is, the family includes, regardless of the place of residence (stay) or registration of children attending full-time education in general educational, vocational, higher educational institutions of I-IV levels of accreditation up to 23 years and do not have their own families. The family does not include persons who are fully supported by the state.

Thus, there is no single approach to the identification of low-income and possible abuse of these persons as subjects of free secondary legal assistance.

2. Unequal interpretation of the issues of "social protection" as a sign of receiving secondary legal assistance for war veterans without taking into account their income.

\footnotetext{
${ }^{17}$ Family Code of Ukraine: Law of Ukraine of Jan. 102002 No. 2947-III. Vidomosti of the Verkhovna Rada of Ukraine (VVR), 2002, No. 21-22, p. 135.

${ }^{18}$ On state social assistance to low-income families: Law of Ukraine of June 1, 2000. Vidomosti of the Verkhovna Rada of Ukraine (VVR), 2000, No. 35, p. 290.
} 
National legislation does not provide a clear interpretation of the concept of "social protection". Article 46 of the Constitution of Ukraine it is said that citizens have the right to social protection, which provides for the right to provide, in the event of complete, partial or temporary disability, loss of a breadwinner, unemployment due to circumstances beyond their control, as well as in old age and in other cases provided for by law ${ }^{19}$. This led to a narrowing of the legal protection of war veterans.

Internally displaced persons cannot receive a certificate of family composition at their registered place of residence in the anti-terrorist operation zone as a document to confirm the status of a low-income family and receive free secondary legal assistance.

Thus, from the above, the following legislative problems can be distinguished.

Thus, from the above, the following legislative problems can be distinguished.

1) The Law of Ukraine "On Free Legal Assistant" (paragraph 2, part 1, Article 15$)^{20}$ limits the range of subjects providing free secondary legal assistance only to lawyers included into the Register of Lawyers providing this assistance, and therefore does not take into account the conventional human right to choose a lawyer. This leads to a decrease in the effectiveness of the provision of legal assistance by lawyers and the loss of legal independence as a self-governing professional institution.

2) Determining the composition of the family to confirm the need for poverty as a qualifying requirement for secondary legal assistance.

The legal conflict arose due to the unequal determination of the composition of the family in order to assign the subject for the right to free secondary legal assistance as a member of a poor family.

3) There is an ambiguous interpretation of social protection as a sign of legal assistance.

Therefore, we are convinced that the solution to these issues requires the intervention of legislators who, within the limits of their competence, will give a positive solution to these problems, taking into account the European experience on those issues.

Even today, there are many important tasks ahead of the free legal assistance system to improve its work. Among these tasks, lawyers pay special attention to solving the problem of the quality of the provision of free secondary legal assistance.

\footnotetext{
${ }^{19}$ Constitution of Ukraine: Law of Ukraine of 06.28 .1996 No. 254k/96-VR. Vidomosti of the Verkhovna Rada of Ukraine (VVR), 1996, No. 30, p. 141.

${ }^{20}$ About free legal assistance: Law of Ukraine dated 02.06.2011 No. 3460-VI. Vidomosti of the Verkhovna Rada of Ukraine (VVR), 2011, No. 51, p. 577.
} 
Ensuring the right to free legal assistance, in accordance with Art. 6 of the Convention should not be formal but real. Free legal assistance, guaranteed under Art. 6 paragraph 3, must be "concrete and effective". That is, the appointment of a public defender does not yet imply the effectiveness of such assistance, since an ex officio lawyer may die, be seriously ill, face longstanding obstacles or evade his or her duties (Artico v. Italy, paragraph 33).

Undoubtedly, coordinating efforts to ensure the quality of legal assistance is a serious step forward. The unity of views of the state legal assistance system, a professional lawyer association and non-governmental organizations can become one of the key elements of the unification of legal assistance approaches that will facilitate the networking of legal assistance providers.

The result of this collaboration was the introduction of a new quality assurance tool, called Peer Review. In fact, Peer Review is an expert rating used in scientific research, in the system of expert research and in the provision of professional assistance (including medical and legal). It is a system where independent experienced experts practice assessing the quality of work of other professionals based on specific criteria and defined levels of performance that are agreed upon in the professional community.

The concerns of the advocacy community about the implementation of the Peer Review concept in the free legal assistance system are likely to continue. However, Peer Review is the one tool that will keep a balance between resolving the problem of improving the quality of legal assistance and the guarantees of advocacy.

A series of expert consultations on improving the governance model to enhance independence and the effectiveness of the legal assistance system were held in March 2018 as part of the project "The Affordable and HighQuality Legal Assistance in Ukraine" and the project of the Council of Europe "Further Support for Criminal Justice Reform in Ukraine".

In September 2018, the expert meetings on the development of a management model concept to strengthen the independence and effectiveness of the free legal assistance system in Ukraine were held. The result was the development of a draft concept of the "FLA System Supervisory Board" and a draft resolution of the Cabinet of Ministers of Ukraine "On Amendments to the "Regulations on the Legal Assistance Coordination Center".

In addition, in July 2018, the Project organized a visit to Canada for representatives of the Ministry of Justice and the Legal Assistance Coordination Center to study Canada's experience in developing free legal assistance systems, including the creation and operation of various models of the free legal assistance management systems, as well as the establishment and deepening of working relationships and the exchange of experience between the Ukrainian FLA system and Canadian legal support organizations assistance in the provinces of Nova Scotia and British Columbia. 
The project "Affordable and High-Quality Legal Assistance in Ukraine" is ready to continue to draw on the best Canadian expertise to develop policies and procedures that will govern the future of the Supervisory Board, as well as to foster the Council's capacity as a newly created innovative institution in the area of access to justice.

The Council of Europe, as a long-standing and key partner of the FSLA system in Ukraine, has encouraged and allied independent public initiatives aimed at improving the legal assistance system. The project involved newly recruited lawyers in the legal assistance system, about 500 people from all regions of Ukraine. Pravokator Law Clubs were chosen as the venue - new venues for the interaction and exchange of experience of free legal assistance lawyers, judges, prosecutors and public experts established in the FLA system in 2017, including the support of the Council of Europe.

Lawyers have been provided with effective tools to protect the rights and representation of persons entitled to legal assistance. In particular, lawyers have learned the answers to the most common questions regarding all stages of criminal proceedings, from detention to appeal against a decision in a higher court. All aspects were considered in the light of the case law of the European Court of Human Rights - lawyers discussed which is the best way to apply legal mechanisms to protect client's rights in criminal proceedings.

The free legal assistance system disseminates best practices in the legal environment by teaching not only lawyers but also other parties to criminal proceedings. The main objective of the trainings was to discuss the best ways to provide legal assistance in accordance with the Criminal Procedure Code of Ukraine in the light of the European Convention on Human Rights. Today, the ECtHR Convention and Practice remains a kind of exotic in Ukrainian courts, while trainings allow lawyers of the free legal assistance system to apply the best international standards in their work.

A series of trainings helps to achieve several important goals. On the one hand, the project is aimed at enhancing the individual professional abilities of the lawyers of the FLA system, and therefore helps the system to become stronger and more professional. On the other hand, through cooperation with the Ukrainian Legal Assistance Foundation and other expert NGOs, it deepens the cooperation with civil society and demonstrates the importance of the FLA system as a social phenomenon. The right to an attorney is an integral part of the right to fair justice, which in turn is a cornerstone of legal reform in Ukraine.

In addition, the institutionalization of training is very important, as the standardized program and materials developed through the project can continue to be used independently and systematically in the FLA system, regardless of the projects of the Council of Europe. Similarly, a group of 
trainer lawyers, co-sponsored by the Council of Europe, operates without the need for mandatory external support.

Initial steps in the implementation of the mechanism have shown that it is indeed capable of changing the situation of assessing the quality of legal assistance and will become an important tool in the quality management system of legal assistance.

The administrative burden involved in handling legal assistance applications should be minimized. The legal framework should be improved to clearly determine the persons eligible for FLA and become simpler and more understandable to recipients of legal assistance. This can be achieved by ensuring that a separate and integrated legal assistance law comprehensively and uniformly covers all relevant aspects of legal assistance and safeguards, thus avoiding confusion in the law.

The FLA law or related by-laws should be amended to clarify whether or not legal assistance is provided throughout the proceedings; a clear procedure for the provision of legal assistance should also be developed if it is not provided throughout the proceedings.

Criminal justice entities, in particular the police, prosecutors, courts and the legal assistance system, should work together to ensure that any suspected/accused person is provided with legal assistance, from the moment of detention, to the first interrogation by police, as required by Ukrainian law and practice of the ECtHR. This may include developing (and, where appropriate, updating) by-laws that would provide early access to a lawyer for each institution concerned. Automatic detention of all suspected/accused detainees and timely notification to the RCFLA of the need to appoint a lawyer are also required. In addition, the prosecution of the only persons who are guilty and the exclusion of testimony obtained without a lawyer from the moment of detention and before the first interrogation by the police ("Salduz principle") is in the interests of the public, the police and lawyers. Therefore, training should be organized on this principle and the consequences of its violation among all relevant parties interested.

The FLA Law should specify the time limits within which legal assistance decisions may be challenged and the procedure to be followed. The various provisions on legal assistance appeals, which now contain different articles of the FLA Law, could be transposed into a single set of provisions, including review and appeal.

There is a need to improve the order in which information (oral and written) is retained in conjunction with the recording of the conversation so that the public and the lawyers are assured that their rights are properly communicated to the public. The more often this is done, the more people will be aware of their rights to information and effective protection. The 
availability of primary legal assistance in criminal matters can also be used for this purpose.

It would be useful for different institutions of the criminal justice system to collect and process statistics using similar indicators so that legal assistance data can be compared with statistics of law enforcement agencies and courts, and thus to know the percentage of criminal cases (proceedings) in which the legal assistance was necessary to be provided, and the percentage of actual recipients of legal assistance, and the reasons for any possible differences.

\section{CONCLUSIONS}

The international legal norm on the right to protection has largely been established under the influence of national legislation and the legal practice of states. However, it is obvious that national law also has a significant impact on international legal perceptions of the right to protection, especially through the prism of the ECtHR and other international human rights bodies.

In international criminal courts, the right to personal protection is regarded as an inalienable right of every accused person. As a rule, it cannot provide more effective protection than that of a qualified lawyer. It seems necessary to place greater emphasis on the qualifications of a lawyer in the international criminal justice system by providing for the experience of the applicant in the international criminal justice system, or at least the need to undergo appropriate internships or training before admitting such a person to practice as a lawyer.

Analyzing the peculiarities of the provision of such services in the European countries, it is concluded that Ukraine has already begun to move forward, taking over the European experience. The examples include primary and secondary legal assistance centers operating in all areas of Ukraine that are close to European standards. On the basis of the recommendations of the Council of Europe report on supporting the development of a free legal assistance system, it is proposed to improve the transparency of the appointment of lawyers, to strengthen the quality control mechanisms for the provision of legal assistance, to simplify the existing system of payment of lawyers based on European experience, to encourage attorneys to represent clients, and the development of electronic exchange of information between relevant authorities to ensure greater coherence in relevant authorities, their effectiveness and the improvement of service delivery to the public.

\section{SUMMARY}

The scientific publication examines the standards of access to professional legal assistance in accordance with the legislation of Ukraine and European legal doctrine. The legal framework of the Ukrainian legislation regulating the 
implementation of European standards of access to professional legal assistance is analyzed. Initial steps in the implementation of the mechanism have shown that it is indeed capable of changing the situation of assessing the quality of legal assistance and will become an important tool in the quality management system of legal assistance. The results of modern studies of the evaluative nature of public policy, which regulates the introduction of standards into Ukrainian legal realities, are characterized. The key issues relating to the provision of free legal assistance are highlighted. Initial steps in the implementation of the mechanism have shown that FLA is indeed capable of changing the situation of assessing the quality of legal assistance and will become an important tool in the quality management system of legal assistance. The author defines a system of recommendations that will help to implement European experience in the provision of professional legal assistance.

\section{REFERENCES}

1. Goncharenko S. V. Problems of providing free legal assistance. A brief overview of the latest trends // The Lawyer. 2011. № 11. P. 12-16.

2. Convention for the Protection of Human Rights and Fundamental Freedoms of 04/04/1950. Convention by Law No. 475/97-VR of 07.17.97.

3. Constitution of Ukraine: Law of Ukraine of 06.28.1996 No. 254k/96-VR. Vidomosti of the Verkhovna Rada of Ukraine (VVR), 1996, No. 30, p. 141.

4. International Covenant on Civil and Political Rights of 12.16.1966. The International Covenant was ratified by Decree of the Presidium of the Supreme Council of the Ukrainian SSR N 2148-VIII (2148-08) of 10.19.73.

5. The Bar and Advocacy: The Law of Ukraine of July 5, 2012, Vedomosti of the Verkhovna Rada (VVR), 2013, No. 27, p. 282.

6. About free legal assistance: Law of Ukraine dated 02.06.2011. No. 3460-VI. Vidomosti of the Verkhovna Rada of Ukraine (VVR), 2011, No. 51 , p. 577.

7. On refugees and persons in need of additional or temporary protection: Law of Ukraine of July 8, 2011. Vidomosti of the Verkhovna Rada of Ukraine (VVR), 2012, No. 16, p. 146.

8. On state social assistance to low-income families: Law of Ukraine of June 1, 2000. Vidomosti of the Verkhovna Rada of Ukraine (VVR), 2000, No. 35, p. 290.

9. On the Concept of the formation of a system of free legal assistance in Ukraine: Decree of the President of Ukraine of June 9, 2006 No. 509/2006.

10. On the protection of childhood: Law of Ukraine of April 26, 2001. Vidomosti of the Verkhovna Rada of Ukraine (VVR), 2001, No. 30, p. 142. 
11. On the living wage: Law of Ukraine of July 15, 1999. Vidomosti of the Verkhovna Rada of Ukraine (VVR), 1999, No. 38, p. 348.

12. About the status of war veterans, guarantees of their social protection: the Law of Ukraine of October 22, 1993. Vidomosti of the Verkhovna Rada of Ukraine (VVR), 1993, No. 45, p. 425.

13. Issues of the decentralization process of service delivery in the united territorial communities: a collection of roundtable papers and abstracts, Kyiv, April 18, 2019 / under gen. ed. of R.V. Voitovych, P.V. Vorona. Kyiv, “ArtEk", 2019. 217 p.

14. Sverba Yu. Peer Review: step by step to the quality of free legal assistance // Legal Newspaper. № 40 (694). 2019.

15. Family Code of Ukraine: Law of Ukraine of Jan. 102002 No. 2947-III. Vidomosti of the Verkhovna Rada of Ukraine (VVR), 2002, No. 21-22, p. 135.

16. Forming of the free legal assistance system in Ukraine [Electronic source]. Available at: http://legalaid.gov.ua/ua/operatyvna-info/formuvanniasystemy.

17. Legal assistance in Europe: minimum requirements under international law [Electronic source]. Available at: http://osf.to/legal-aid-standards.

\section{Information about the author: \\ Oksana Krushnitska,}

Postgraduate Student at the Department of Procedural Law, Yuriy Fedkovych Chernivtsi National University 22, Fedkovicha str., Chernivtsi, 58000, Ukraine ORCID ID: orcid.org/0000-0003-1693-9867 


\section{DEFECTS OF LEGAL TECHNIQUE AND POSSIBLE WAYS OF THEIR OVERCOMING IN THE REGULATION OF THE FORMATION OF PHYSICAL EVIDENCE AND SOLVING THE ISSUE ABOUT THEM IN THE CRIMINAL PROCESS OF UKRAINE}

\section{Iryna Krytska}

\section{INTRODUCTION}

An indispensable attribute of the legal culture of society is the level of development of law. First of all, it is about the culture of legal texts - the proper degree of law-making. It is inextricably linked to the level of progressiveness and adequacy of law enforcement activities.

An exceptional place in ensuring the proper level of law-making and enforcement activities is given to legal technique, as it is intended to solve the problems of construction of legal structures, issues of legal terminology, rules for the development, presentation and systematization of regulations. Certainly, any normative act must be perfect both in terms of its content, that is, in conformity with the notions of justice, equality and freedom, and in terms of its form. Therefore, the law, including criminal procedural law, should be consistent, optimal in scope, clear, logical and understandable to the population. Obviously, such a negative phenomenon, as the imperfection of legal technique in the regulation of certain issues of criminal proceedings, calls into question the high level of legal culture and impedes its potential and necessary improvement.

Against this background, the identification of gaps and conflicts in the normative regulations of certain aspects of criminal proceedings and finding out ways of their possible overcoming are of permanent relevance. At the same time, given the reasonable boundaries of our work, fully aware of the inability to cover the variety of defects in criminal procedural law, the subject of our study is identified in such a direction as the formation of material evidence and the resolution of the issue about them in criminal proceedings. In our view, this direction is relevant, since it is inextricably linked to the issue of balancing the task of criminal proceedings, such as ensuring prompt, complete and impartial investigation and trial, along with the inadmissibility of any unjustified procedural coercion against any person. At the same time, the formation of material evidence and the resolution of the question about them is always closely intertwined with the restriction and deprivation of the property right of a person which is central to the system of socio-economic 
rights and freedoms of citizens and enshrined in Art. 41 of the Constitution of Ukraine along with such fundamental human rights as the right to life, liberty, privacy and the like.

\section{Defects of legal technique in the regulation of the formation of physical evidence}

The starting point in assessing the adherence to the proper procedure for the formation of material evidence in criminal proceedings, apparently, is the steady adherence to the procedural form, which, in particular, is manifested in the drafting of the necessary procedural documents that would certify the lawfulness of the entry of the relevant material object in the criminal proceedings. However, unlike the CPC of 1960, as well as the codes of some other states (for example, the Republic of Kazakhstan ${ }^{1}$, the Republic of Moldova $^{2}$, etc.), the Ukrainian CPC does not explicitly require that a material object be recognized the physical evidence by the adopting a decision. Said lack of regulation led to the appearance of plurality of views on this issue among researchers and practitioners.

A systematic analysis of the case law shows that the authorized entities usually not only draw up the protocol of inspection of the subject, but also issue a corresponding decree recognizing his material evidence. However, this practice raises many questions for some scholars. For example, L.M. Loboyko, while giving a negative assessment of such a law enforcement practice and emphasizing its residual nature, indicates that drawing up of such decision by the prosecution puts the defense party in a clearly disadvantageous situation and testifies to the existence in the criminal proceedings of unjustified superiority of the prosecution party ${ }^{3}$. Close to the above approach is the stance of M.Ye. Shumilo, who emphasizes that during the pre-trial investigation, the parties collect materials about sources of future evidence - data carriers of facts and circumstances to be proved. The materials collected by the parties can be admitted as evidence by the results of their interpretation only by the judicial authority, that is, before that neither

\footnotetext{
${ }^{1}$ Ugolovno-processual'nyj kodeks Respubliki Kazahstan ot 04.06.2014 № 231-V. [The Code of Criminal Procedure of the Republic of Kazakhstan dated 04.06.2014 No. 231-V]. Retrieved from: http://online.zakon.kz/Document/?doc_id=31575852\#sub_id=2210400 (accessed 25.01.2020)

${ }^{2}$ Ugolovno-processual'nyj kodeks Respubliki Moldova ot 14.03.2003 g. № 122-XV. [The Code of Criminal Procedure of the Republic of Moldova dated March 14, 2003 No. 122-XV]. Retrieved from: http://online.zakon.kz/Document/?doc_id=30397729\&doc_id2=30397729\#pos=30;-15\& sub_id2=1020000\&sel_link=1001129174 (accessed 25.01.2020)

${ }^{3}$ Loboiko L. M. (2014) Spivvidnoshennia danykh dosudovoho rozsliduvannia i dokaziv [Ratio of data of pre-trial investigation and evidence]. Pravo Ukrainy, no.10, p. 86.
} 
the investigator nor any other entity, except the court, can decide that certain factual data should acquire the value of evidence in criminal proceedings ${ }^{4}$.

Legal interpretation of the provisions of Part 3 of Art. 110 of the CPC certifies the formal admissibility of the investigator's or prosecutor's decision to recognize the material object as physical evidence, since the said rule allows the investigator, the prosecutor to make the decision not only in cases directly provided for by the CPC, but also when they consider it necessary. Moreover, O.G. Shilo reasonably points out that the drafting of a separate decree on the involvement in criminal proceedings of objects as material evidence provides certainty in this matter and, taking into account Part 2 of Art. 100 CPC, it seems appropriate ${ }^{5}$. In addition, S. O. Kovalchuk draws attention to the problem of ambiguity of the case-law formed today to resolve the issue of the fate of material evidence and gives examples where domestic courts often refuse to resolve this issue, citing that material objects are not confessed to the decision of the investigator material evidence and did not join the materials of criminal proceedings, as a result of which the court was deprived of the opportunity to make a decision on them in the order of p. 4 Art. 374 or $\S 14$ p. 1 Art. $537 \mathrm{CPC}^{6}$.

In expressing our own view of this issue, it should be noted, first of all, that the investigator's or prosecutor's decision to admit a material object the physical evidence does not mean that these participants decide in advance instead of the court the issue of the relevance, admissibility and authenticity of certain evidence. All of them are independent subjects of the evaluation of the evidence, which they carry out at certain stages of criminal proceedings, taking appropriate procedural decisions.

In addition, the presence or absence of a decision, in our view, plays an important role in resolving the question of the lawfulness of the restriction of ownership of property that has been temporarily removed and seized. Thus, given that the request of the investigator, the prosecutor for the arrest of the temporarily seized property must be filed not later than the next working day after the seizure of the property, and in the case of temporary seizure of the property during the search, examination, carried out on the basis of the

\footnotetext{
${ }^{4}$ Shumylo M. Ye. (2013) Poniattia “dokazy” u kryminalnomu protsesualnomu kodeksi Ukrainy: sproba krytychnoho pereosmyslennia ideolohii normatyvnoi modeli [The notion of "evidence" in the criminal procedural code of Ukraine: an attempt to critically rethink the ideology of the normative model]. Visnyk Verkhovnoho Sudu Ukrainy, no. 2 (150), p. 41

${ }^{5}$ Shylo O. H. (2013) Rechovi dokazy yak protsesualne dzherelo dokaziv [Physical evidence as a procedural source of evidence]. Visnyk prokuratury, no. 6 (144), p.81.

${ }^{6}$ Kovalchuk S. O. (2016) Protsesualna forma rechovykh dokaziv u kryminalnomu provadzhenni [The procedural form of material evidence in criminal proceedings]. Pravo.ua, no. 3, p. 161 . Retrieved from: http://pravo.unesco-socio.in.ua/wp-content/uploads/2016/11/Pravo_ua_2016_31.pdf (accessed 25.01.2020)
} 
decision of the investigating judge, provided for in Art. 235 of the CPC, the request for the seizure of such property should be filed by the investigator, the prosecutor within 48 hours after the seizure of the property, in fact, the seizure may be imposed on the property which is not relevant for the criminal proceedings. However, the investigator, the prosecutor cannot establish this without, for example, the involvement of an expert and an examination, which obviously requires more time than one day.

In view of the foregoing, it seems appropriate to provide in the CPC with the need for the investigator, the prosecutor to issue a decree recognizing the material object as physical evidence no later than five days from the moment of its removal. The investigator, the prosecutor must state the reasons for the decision. However, if the admission of such objects as the physical evidence requires the appointment of an examination, the decision to admit their physical evidence must be made no later than the next working day after receiving the expert's expert opinion. The absence of a decree recognizing a material object as physical evidence should be considered as a ground for canceling the seizure of the property and returning it to its owner.

Some drawbacks of law-making technique are also evident in the aspect of drafting other procedural documents that constitute the procedural form of material evidence. In particular, Part 3 of Art. 168 of the CPC establishes that the investigator, the prosecutor, another authorized officer, during the detention or search and temporary seizure of property, or immediately after their execution, is obliged to draw up an appropriate protocol, a copy of which is provided to the person whose property has been seized or his representative. However, as N. S. Morgun rightly points out, it is unclear why this provision does not provide for the obligation to draw up such a protocol when conducting the review, based on the logic of Part 1 of Art. 168 and Part 2 of Art. 168 CPC. In addition, indeed, the formulation of Part 3 of Art. 168 of the CPC, which uses the phrase "relevant protocol"implies its ambiguous interpretation, since it is not clear what protocol the legislator meant - a procedural action during which a temporary seizure was carried out, or a separate protocol of temporary seizure of property ${ }^{7}$.

We support the view that a separate protocol of temporary seizure during a search, examination or detention is not included in the list of documents to be drawn up in this case ${ }^{8}$, especially since, in accordance with Part 9 of Art. 236

7 Morhun N. S. (2014) Tymchasove vyluchennia maina yak zakhid zabezpechennia kryminalnoho provadzhennia, shcho obmezhuie pravo vlasnosti [Temporary seizure of property as a measure to ensure the criminal proceedings, which restricts ownership]. Mytna sprava, no. № 3(2), pp. 321-322.

${ }^{8}$ Shylo O. H. (2013) Rechovi dokazy yak protsesualne dzherelo dokaziv [Physical evidence as a procedural source of evidence]. Visnyk prokuratury, no. 6 (144), pp. 79-80. 
of the CCP, the second copy of the search protocol, together with the description of the seized documents and temporarily seized items, if any, shall be handed over to the person who has been searched, and in case of absence an adult member of his (her) family or his (her) representative. So no need to double duplicate the same information. Therefore, it seems to us that the provisions of Part 3 of Art. $168 \mathrm{CCP}$ does not have any meaning and should be excluded in order to provide legal certainty.

Manifestation of legal uncertainty are also some issues of regulating the need for seizure of items that are excluded by law from circulation. Yes, we have to ascertain the existence of a conflict between the provisions of Part 2 of Art. 167 CPC on the one hand and Part 7 of Art. 236, part 7 of Art. 237 CPC on the other. In particular, paragraph 3 of Part 2 of Art. 167 of the CPC provides that temporarily seized property may be seized in the form of things, documents, money, etc. for which there are sufficient grounds to believe that they are the subject of a criminal offense, including those related to their illicit trafficking. At the same time, the analysis of Part 7 of Art. 236, as well as Part 7 of Art. 237 of the CCP, on the contrary, indicates that only seized items and documents that do not relate to items that have been seized by the law are considered temporarily seized property.

In the light of the above, we will cite the thesis of S. Smokov and D. Lisnichenko, according to which if if during the search were found objects and items which withdrawal from circulation can only confirm the findings of relevant examinations, in which case these things are considered temporarily seized property and require the investigator to resolve the issue of their arrest ${ }^{9}$. Indeed, the examination may show that the item removed does not belong to objects that are prohibited for circulation. And in this case, if the object was not previously seized by a court decision, a situation arises when the property right of the person is restricted without due legal basis. Considering the above, in our opinion, practice to arrest all seized during the search and review for housing or other property items, including those that were listed in the order the investigating judge for permission to conduct an appropriate investigation (search) action is correct. And so it seems appropriate to lay down the provisions of Part 7 of Art. 237 CPC read as follows: “... objects that are excluded by law from circulation, be withdrawn, regardless of their relationship to criminal proceedings. Seized items and documents are considered temporarily seized property". Similarly, we propose to amend to Part 7 of Art. 236 of the CPC: “... Items removed and documents not included

${ }^{9}$ Smokov S., Lisnichenko D. (2015) Tymchasove vyluchennia ta aresht maina: dokaz chy zakhid zabezpechennia kryminalnoho provadzhennia [Temporary removal and seizure: evidence or a measure ensuring criminal proceedings]. Pravo Ukrainy, no. 5, p. 165. 
in the list for which a search permit was explicitly granted in the search permit shall be considered temporarily seized property."

Also relevant in our study is the issue of regulating the proper procedure for generating such a kind of material evidence as digital sources of evidence. Unfortunately, Ukrainian criminal procedural legislation does not take into account the rapid development of scientific and technological progress. Therefore, there are no provisions in the CPC that would govern the review of such a storage medium. It is quite obvious that an inspection of an object in its traditional sense only provides a visual observation of the features of the relevant material object (mobile phone, tablet, flash drive, etc.). Therefore, as R.I. Okonenko points out, it is more appropriate to use the concept of "digital device search", which will correspond to the nature of the investigative action, which is carried out in this case ${ }^{10}$. At the same time, in our view, it is more appropriate to apply in this case a procedure for temporarily accessing such information by reading and copying it, which can be done to overcome the system of logical protection and to obtain the specified access using specialized knowledge.

Continuing consideration of the issues raised, it should be noted that digital (electronic) information has certain characteristics, which, in our opinion, can testify to its special procedural status, namely: the absence of a firm bond with the material carrier; broadcastability, ie the ability to be transferred from one carrier to another; multiplicity - the possibility of simultaneous existence on different media; the need for compulsory interpretation and transcoding by means of specialized hardware and software; variability, which is manifested in the possibility of remote modification of electronic information and its destruction.

Therefore, de lege ferenda (from the point of view of the law which is desirable), in our view, seems to be a more successful approach, aimed at isolating electronic information as an independent procedural source of evidence, as, for example, in Latvia's Criminal Procedure Code (Art. 136 "Electronic Evidence"), as well as in the Code of Administrative Procedure of Ukraine (Article 99), Civil Procedure (Art. 100) and Economic Procedural (Art. 96) Codes of Ukraine.

${ }^{10}$ Okonenko R.I. (2016) Elektronnye dokazatel'stva i problemy obespecheniya prav grazhdan na zashchitu tajny lichnoj zhizni $v$ ugolovnom processe: sravnitel'nyj analiz zakonodatel'stva Soedinennyh S. Htatov Ameriki i Rossijskoj Federacii [Electronic evidence "and the problems of ensuring the rights of citizens to protect the secrets of their personal lives in criminal proceedings: a comparative analysis of the laws of the United States of America and the Russian Federation] (PhD Thesis), Moskva: Moskovskij gosudarstvennyj yuridicheskij universitet imeni O.E. Kutafina, pp. 120-121. 
Note also appears that the actual is a problem with the possible complete or partial destruction (and depletion) a material object aimed at examination during its conduct.. It should be noted in the context that the method of carrying out some examinations does not always allow to preserve a complete material object, which can be recognized as material evidence in criminal proceedings, and the amount of the test substance may not be sufficient for possible further examination by the defense party. However, this issue remains unresolved at the regulatory level. At the same time, there are some developments in the science of criminal procedural law in this area. Thus, for such situations, both Ukrainian and foreign scientists propose to provide a procedure for depositing material evidence at a pre-trial investigation by an investigating judge in the presence of the parties ${ }^{11}$. We consider the stated scientific positions to be worthy of support, since the application of the depositing allows to move the process of examination of physical evidence to the stage of pre-trial investigation with the participation of the investigating judge and parties before the start of the examination and possible destruction or complete expenditure of the material object, which, in particular, facilitates ensuring the implementation of the principle of competitiveness in criminal proceedings.

Based on the above, we consider it advisable to propose to establish in the CPC a special procedure for expert examination of material objects in case of their possible destruction or complete expenditure during the examination. Such a mechanism should include the following requirements: (1) if necessary to order an expert examination during the pre-trial investigation, which results in a material object, due to its own characteristics, a small number, peculiarities of the study, etc., may be destroyed or completely used, the investigator, the prosecutor must petition the investigating judge deposit of this object; (2) application of the depositing should be considered within three days of its filing in court with the obligatory call parties to criminal proceedings. However, the non-arrival of the defense party duly notified of the place and time of the court hearing to participate in the investigation of the material object and the appointment of the relevant expert examination at the request of the prosecution party does not prevent such actions in the court hearing; (3) during the court hearing, the material object and its outwardly

${ }^{11}$ Gambaryan A.S. Sudebnoe i notarial'noe deponirovanie pokazanij po iniciative advokata kak sredstvo garantirovaniya nezavisimosti advokata [Judicial and notarized deposition of evidence at the initiative of a lawyer as a means of guaranteeing the independence of a lawyer] (unpublished). Retrieved from: http://www.iuaj.net/node/1745 (accessed 25.01.2020); Aleksandrov A.S., Kovtun N.N. Grachev S.A i drugie. Doktrinal'naya model' ugolovno-processual'nogo dokazatel'stvennogo prava Rossijskoj Federacii [Doctrinal model of criminal procedural evidence of the Russian Federation] (unpublished). Retrieved from: http://www.iuaj.net/node/1766(accessed 25.01.2020) 
accessible external features are examined by the investigating judge and the parties to the criminal proceedings. An investigating judge, either on the initiative of the parties or on his own initiative, may involve a specialist to assist in the study of the properties of the material object; (4) the process of investigating the material object by the investigating judge and the parties must be fully recorded in the court journal and the technical record of the trial; (5) after investigating the object, the investigating judge shall appoint a commission examination by his decision. The commission must consist of at least three persons, and the parties are entitled to recommend one expert to participate in the examination of a number of persons who, according to the Law of Ukraine "On Forensic Expertise", may be a judicial expert. Another expert is selected by the investigating judge; (6) the decision of the investigating judge on the involvement of the expert and the appointment of the examination must be accompanied by written permissions of the parties to the prosecution and defense to the possible destruction or complete expenditure of the object of investigation during the examination; (7) the presence of a criminal procedural sanction in the event of a party's violation of such an order, namely, the remnants of a material object and the expert's opinion obtained must be recognized as clearly inadmissible evidence.

\section{Defects of legal technique in the regulation of the solving the issue about physical evidence}

Particular attention is required to analyze the activity, which is also inextricably linked to the production and use of material evidence in criminal proceedings. It is about resolving the issue of material evidence. In particular, within the scope of our research, it seems appropriate to dwell on the particular problems that arise in resolving the issue of material evidence in criminal proceedings, in order to identify legislative conflicts and gaps in this area and formulate proposals aimed at overcoming them.

First of all, we note not very successful, in our opinion, the formulation of Part 9 of Art. 100 CPC. According to this rule, in the case of criminal proceedings being closed by the investigator or prosecutor, the issue of special confiscation and the fate of material evidence and documents shall be resolved by a court order on the basis of a corresponding request, which is considered in accordance with Articles 171-174 of the CPC. Based on the content of the said provision, it is not clear when it is for the investigator or the prosecutor must petition to resolve the issue of material evidence - either before the decision to close the criminal proceedings or after. Such legal uncertainty leads to the appearance of relevant misunderstandings in law enforcement practice. Thus, by the decision of the Kyiv District Court of Kharkiv dated March 24, 2017, the request of the investigator for special confiscation and 
the fate of material evidence was denied on the grounds that "in accordance with paragraph 5 of Part 1 of Article 3 of the CPC of Ukraine, the pre-trial investigation - the stage of criminal proceedings, which begins from the moment of entering information about a criminal offense in the Unified register of pre-trial investigations and ends with the closure of criminal proceedings or the referral to court of indictment, the application for coercion $\mathrm{s}$ measures of medical or educational nature, an application for exemption from criminal liability. Considering that the pre-trial investigation in criminal proceedings, within the framework of which the measure of securing criminal proceedings in the form of seizure of property was applied, has now been completed by the decision of the investigator to close the criminal proceedings, according to the provisions of Part 9 of Article 100, Part 1 Art. 170, Part 1 Art. 174 CPC investigating judge is not entitled to decide the fate of material evidence. Moreover, since the decision of the investigator to close the criminal proceedings, the investigator has lost the procedural opportunity to appeal to the investigating judge with a request for special confiscation and fate of material evidence" 12 .

This reasoning seems quite logical, since after the closure of criminal proceedings the issue of special confiscation and the fate of material evidence should be resolved in the framework of some separate proceedings, but the CPC does not envisage such a procedure. In our opinion, it is considered correct to address the investigator or the prosecutor to the investigating judge with a request to resolve the issue of material evidence prior to the decision to close the criminal proceedings.

At the same time, there is another problem with the possible loss of material evidence in the case of unjustified closure of criminal proceedings. According to Part 6 of Art. 284 of the CPC within twenty days from the receipt of a copy of the investigator's decision to close the criminal proceedings, the prosecutor has the right to cancel it due to illegality or groundlessness. The investigator's decision to close the criminal proceedings may also be quashed by the prosecutor on the complaint of the applicant, the victim, if such a complaint is lodged within ten days of the receipt by the applicant, the victim, of a copy of the decision. In addition, the CPC also provides for the possibility of challenging the decision of the investigator or prosecutor to close the criminal proceedings to the investigating judge within ten days from the day the person receives a copy of the decision.

${ }^{12}$ Ukhvala Kyivskoho raionnoho sudu m. Kharkova vid 24 bereznia 2017 r., sudova sprava № 640/4053/17. Retrieved from: http://reyestr.court.gov.ua/Review/\%2065609636 (accessed 25.01.2020) 
Given this, it seems appropriate to clarify the provisions of Part 9 of Art. 100 of the CPC, stating that if an investigator or prosecutor concludes that there are grounds for closing a criminal proceeding, they should apply to the investigating judge for special confiscation and to resolve the issue of material evidence and documents prior to the decision to close the criminal proceedings. At the same time, the appeal of the decision of the investigator or the prosecutor to close the criminal proceedings in accordance with the procedure provided by the CPC, shall suspend the entry into force of the decision of the investigating judge, delivered after the consideration of such request, and its execution.

In addition, in accordance with the prescription established by Part 5 of Art. 284 of the CPC, namely that the decision of the prosecutor to close the criminal proceedings against the suspect is not an obstacle to the continuation of the pre-trial investigation into the relevant criminal offense, we offer provide in Part 9 of Art. 100 CPC in such cases should be resolved only the question for the restitution of property of the person against whom ordered the closure of criminal proceedings.

As the case law shows, certain difficulties arise in cases where material evidence containing no traces of a criminal offense, in the form of objects, large consignments of goods whose storage due to cumbersome or other reasons is impossible without unnecessary difficulty or the expense of securing special conditions of storage which are commensurate with their value, as well as material evidence in the form of goods or products that are perishable can be transferred for sale, if possible without prejudice to criminal process or the destruction if such goods or products are subject to perishable deterioration.

The most illustrative example is the decision of the investigating judge of the Mlynivsky district court of Rivne region, who refused to satisfy the request of the investigator to grant permission for the sale of physical evidence, since the criminal proceedings lack information about the request of the investigator to the owner of the timber upon his / her consent to the realization of physical evidence, or information that would indicate the absence of such consent ${ }^{13}$. That is, in the opinion of the investigating judge, granting the court permission to present material evidence is possible only if such permission of the property owner is refused. At the same time, the analysis of paragraphs 2-3 of Part 6 of Art. 100 of the CPC does not warrant such an unambiguous conclusion, since the wording "... with the written consent of the owner, and in the absence of the decision of the investigating judge, court..." may indicate that the realization and destruction

${ }^{13}$ Ukhvala Mlynivskoho raionnoho sudu Rivnenskoi oblasti vid 10 kvitnia 2017 r., sudova sprava № 566/154/17. Retrieved from: http://reyestr.court.gov.ua/Review/65866021(accessed 25.01.2020) 
of certain types of material evidence are possible on the basis of or alternatively, the consent of the owner, or the decision of the investigating judge, court. Therefore, to ensure legal certainty, we propose to adjust the provisions of paragraphs 2-3 of Part 6 of Art. 100 of the CPC as follows: “... with the written consent of the owner or upon the decision of the investigating judge, court...".

In light of the problem raised, it is appropriate to pay attention to Part 8 of Art. 100 of the CPC, according to which the realization, technological processing or destruction of physical evidence in the cases provided for in this Article shall be carried out in accordance with the procedure established by the CMU. In particular, according to Sec. 2 paragraph 28 of the Procedure of storage of physical evidence, realization of objects is carried out in compliance with the requirements of the Procedure of accounting, storage, valuation of confiscated and other property that passes into state ownership, and its disposal, approved by the Cabinet of Ministers Resolution of August 25, 1998 No. 1340. In this case, the proceeds from the sale of property confiscated by a court decision shall be credited to the state budget, less the amount of commission paid to the enterprise, institution, organization charged with managing the property under the concluded agreement. However, it is obvious that the procedure for transferring funds obtained from the sale of material evidence at the stage of pre-trial investigation may not be identical to the procedure for transferring funds received from the sale of confiscated property, since at the time of the decision on the sale of material evidence, in the order provided for in paragraph 2 Part 6 Article 100 of the CPC, the person's guilt of committing a criminal offense has not been definitively and authentically established. Therefore, in our opinion, the enrollment of the funds received from the realization of material evidence to the state budget, seems not quite correct.

Instead, based on the content of the decision of the investigating judge Kovel City Court of Volyn region of 22.09.2015, the investigator was granted permission to sell 93 logs of pine timber in the procedure established by the $\mathrm{CMU}$, which were recognized as material evidence in the criminal proceedings, and stated that from the sale of $93 \mathrm{logs}$ of pine wood, the money is sent to the state revenue ${ }^{14}$.

To solve this conflict, in our opinion, it is advisable to provide an algorithm of action similar to that established by Art. 182 CPC on deposit of money in the form of collateral. According to Part 1 of this Article, the pledge is to deposit funds in the currency of Ukraine into a special account, determined in the manner established by the CMU. Pursuant to Item 2 of the

${ }^{14}$ Ukhvala Kovelskoho raionnoho sudu Volynskoi oblasti vid 22 veresnia 2015 r., sudova sprava № 159/5016/15-k. URL: Retrieved from: http://reyestr.court.gov.ua/Review/50960608 (accessed 25.01.2020) 
Procedure for depositing funds into a special account in case of application of the pledge as a precautionary measure approved by the Cabinet of Ministers Resolution No. 15 of January 11, 2012, the pledge shall be deposited in the national currency into a special account of the territorial administration of the State Judicial Administration, which performs organizational and financial support of the court. A similar approach is found in the criminal procedural legislation of some foreign states (in particular, for example, part 3 of Article 161 of the CPC of Moldova ${ }^{15}$ establishes that when the material evidence is transferred to the tax authorities for their sale, the resulting funds are transferred to the deposit account of the respective prosecutor's office or court). In view of the above, we propose to supplement Part 8 of Art. 100 $\mathrm{CPC}$ in a sentence, stating it in the following wording: "The funds received from the sale of physical evidence are credited to the special deposit account of the court that made the decision on such realization."

In the light of the analysis of the shortcomings of the legal technique regarding the resolution of the issue of material evidence, let us also consider the situation when, in the judgment of the court of first instance, contrary to the imperative instructions enshrined in Part 9 of Art. 100, Part 4 of Art. 374 of the CPC, regarding the need to resolve the issue of material evidence in a court decision terminating criminal proceedings, this issue was not resolved. The above problem can be caused by several factors: 1) certain legal conflicts - in particular, in cases where the CCP provides for differentiation of criminal procedural form (for example, the so-called reduced court proceedings provided for in Article 349, part 3 of the CPC, as well as criminal proceedings on the basis of agreements), since in this case the law there is no obligation on the parties to provide material evidence to the court. At the same time, based on the content of Part 9 of Art. 100 of the CPC, the question of the fate of material evidence and documents provided to the court is decided by the court when adopting the court decision, which ends the criminal proceedings ${ }^{16}$; 2) shortcomings of law enforcement practice. In particular, the common are cases where courts do not consciously decide the fate of certain material objects, because they were not considered material evidence separate

${ }^{15}$ Ugolovno-processual'nyj kodeks Respubliki Moldova ot 14.03 .2003 g. № 122-XV. [The Code of Criminal Procedure of the Republic of Moldova dated March 14, 2003 No. 122-XV]. Retrieved from: http://online.zakon.kz/Document/?doc_id=30397729\&doc_id2=30397729\#pos=30;15\&sub_id2=1020000\&sel_link=1001129174 (accessed 25.01.2020)

${ }^{16}$ Uzahalnennia Vyshchoho spetsializovanoho sudu Ukrainy sudovoi praktyky zdiisnennia kryminalnoho provadzhennia na pidstavi uhod vid 22.01.2014 [Generalization of the High Specialized Court of Ukraine of judicial practice of criminal proceedings on the basis of agreements dated 22.01.2014]. Retrieved from: http://zib.com.ua/ua/print/92557-uzagalnennya_vssu_ sudovoi_praktiki_zdiysnennya_kriminalnogo_.html (accessed 25.01.2020) 
decision of the investigator or prosecutor. In addition, such a situation may also occur when the judges leave the issue unconsciously, contrary to the requirements of paragraph 1 of Part 4 of Art. 374 CPC on the content of the resolution part of the sentence. Let us analyze the directions of solving the problem de facto, de jure and de lege ferenda.

De facto. The analysis of the case law on the outlined issue gives the grounds to distinguish three main ways that are most common among judges: (1) "correction of records" with reference to Art. 379 CPC; (2) in order to resolve issues arising during the execution of sentences, in accordance with Art. 537 and Art. 539 CPC; (3) in the order of appeal, on the basis of which the courts of appeal, guided by Art. 409 CPC, change the court decisions of the first instance regarding the determination of the fate of material evidence.

De jure. It should be noted that the law does not explicitly establish an algorithm of action if the issue of material evidence was not resolved by the court at the time of adopting the court decision, which ends the criminal proceedings. Therefore, in this section, we analyze each of the above paths in terms of their relevance to address the issue.

With regard to the first of the options we have identified, it should be noted that according to Part 1 of Art. 379 The CPC has the right, at its own initiative or at the request of a participant in a criminal proceeding or other interested person, to rectify the entries made in the court decision of this court, obvious arithmetical errors, whether or not the judgment entered into force. In view of the foregoing, it seems appropriate to agree that "in resolving the issue of rectification of clerical or arithmetical errors made in a judicial decision, the court does not have the right to change the substance of the judgment, it merely eliminates inaccuracies in the established factual circumstances of the case (for example, the date of the event, numbers and dates of the document, name of the party, surnames of the person, etc.)" ${ }^{17}$. It is obvious that the question of the fate of material evidence cannot be regarded as a mistake by the court of first instance in the operative part of the sentence. Even in cases where the courts have motivated his decision by saying that "... sudom been a typo, but it is not true indicates that the physical evidence in the case has not. However, on the basis of the case file, the court sees a receipt for the preservation of physical evidence seized (received) by the prosecution during criminal proceedings. In view of the foregoing, the court concludes that these errors should be corrected, as they do not affect the substance of the

${ }^{17}$ Blazhivskyi Ye.M., Hroshevyi Yu.M., Domin Yu.M. ta in. (2012) Kryminalnyi protsesualnyi kodeks Ukrainy. Naukovo-praktychnyi komentar: u 2 t. T. 2 [The Criminal Procedure Code of Ukraine. Scientific and practical commentary: in 2 volumes. Vol. 2]. Kharkiv: Pravo, p. 161. (in Ukrainian) 
sentence and are obvious, the evidence of these mistakes is indicated by the materials of criminal proceedings"18, in our opinion, to speak about the existence of the record and the possibility of its correction. In this way, it seems wrong and inappropriate. In view of the above, it should be recognized that such jurisprudence does not correspond to the literal content of Art. 379 of the CPC, and the design enshrined in this norm is not suitable for solving the problem we are considering.

Another possible way of resolving the issue of material evidence, which was not reflected in the final decision, is to appeal to the courts in accordance with the procedure laid down in Art. 537, 539 of the CPC, that is, through the mechanism provided by law for matters to be resolved by the court during the execution of the sentence. Analysis of the normative content of Art. 537 of the $\mathrm{CPC}$, which defines the range of issues that can be resolved by the court in the execution of sentences, indicates that the said rule does not directly provide for the possibility of resolving the issue of material evidence. However, the list enshrined in Part 1 of Art. 537 of the CCP is not exhaustive, since paragraph 14 of this article allows other issues to be resolved on all sorts of doubts and contradictions that arise during the execution of the sentence. Contextually note that one of the lexical meanings of the word "doubt" is "complications, misunderstandings that arise when solving any issue, a particular problem"19. In view of this, the courts often state their decision that "the question of any doubt and controversy arising in the execution of a sentence to be resolved by the sentencing court includes the question of the fate of the material evidence and documents, if not resolved by a court judgment" ${ }^{20}$. In our view, such a path is the least objectionable, but to ensure legal certainty requires the introduction of appropriate regulatory adjustments to Art. 537 CPC that will be offered below.

The last of the existing ways of solving the problem identified by us is based on the provisions enshrined in Art. Art. 407, 409 and 412 of the CCP, which determine the order of appeal, whereby the courts of appeal change the decisions of the courts of first instance in determining the fate of the material evidence. In the context of the above, it is necessary to support S. Kovalchuk's position regarding the wrongness of this practice. In particular, the scientist quite rightly

${ }^{18}$ Ukhvala Kyivskoho raionnoho sudu m. Kharkova vid 9 kvitnia 2015 r., sudova sprava № 640/6229/15-k. Retrieved from: http://reyestr.court.gov.ua/Review/43556545 (accessed 25.01.2020)

${ }^{19}$ Slovnyk ukrainskoi movy (1978): v 11 tomakh. T. 9, [Dictionary of the Ukrainian language: in 11 volumes. Vol. 9] Retrieved from: http://sum.in.ua/s/sumniv (accessed 25.01.2020)

${ }^{20}$ Ukhvala Kyivskoho raionnoho sudu m. Kharkova vid 25 liutoho 2016 r., sudova sprava № 640/14342/15-k. Retrieved from: http://reyestr.court.gov.ua/Review/56107677 (accessed 25.01.2020) 
states that the issue of the fate of material evidence, provided that it was not decided by the court of first instance at the time of the court decision, cannot be resolved by the court of appeal, since the rules of the cited articles of criminal procedural law do not provide such an opportunity ${ }^{21}$. Indeed, according to Art. 412 CPC failure to resolve the issue of material evidence does not belong to the list of material violations of the requirements of the criminal procedural law, which are the basis for changing the court decision by the court of appeal. Therefore, in our opinion, it is impossible that the court of appeal can change of a court decision of the court of first instance by supplementing it or clarifying it in order to resolve the issue of material evidence.

De lege ferenda. "In view of the law in need," we consider it appropriate to propose a number of regulatory adjustments that would allow us to avoid legal uncertainty in solving the problem we have stated: (1) to the development of the idea formulated by A.R. Tumanyants and V.V. Kolodchin ${ }^{22}$ it seems appropriate to supplement Art. 349 and Art. 474 of the CPC with statutory provisions that would establish the duty of the prosecutor, even in cases where the CPC provides for differentiation of criminal procedural form, still provide the court with material evidence and documents to resolve the issue in the sentence; (2) in view of the widespread improper practices of judges who do not decide on the fate of material evidence not recognized by such a separate order of the investigator or prosecutor, even though the law does not provide for the obligation to admit it, we propose to further clarify the provisions of Part 9 Art. 100 CPC, pointing out the need to resolve the issue of material evidence regardless of the presence in the criminal proceedings of the decision on recognition of certain material objects; (3) in our opinion, it seems appropriate to supplement the list of issues enshrined in Part 1 of Art. 537 of the CCP, as a separate item that would relate to cases where the issue of material evidence was not resolved at the time of the court decision ending the criminal proceedings.

\section{CONCLUSIONS}

The section has highlighted some of the defects of the legal technique in the regulation of the formation of physical evidence and the resolution of the issue of them in the criminal process of Ukraine and suggested ways to overcome them. In particular, in order to ensure the control of the legality and

${ }^{21}$ Kovalchuk S.O. (2017) Vchennia pro rechovi dokazy u kryminalnomu protsesi: teoretykopravovi ta praktychni osnovy [The doctrine of physical evidence in criminal proceedings: theoretical, legal and practical basis]. Ivano-Frankivsk : Suprun V.P., p. 511. (in Ukrainian)

22 Kolodchyn V.V., Tumaniants A. R. (2016) Povnovazhennia prokurora $v$ sudovomu provadzhenni u pershii instantsii [Powers of the prosecutor in court proceedings at first instance]. Kharkiv, TOV “Oberih”, p. 113. (in Ukrainian) 
validity of the restriction of ownership of property that has been temporarily confiscated and seized, proposed that to predict in the CPC necessity of passing the investigator, prosecutor resolution on recognition of the object material evidence.

In addition, it was noted that the actions taken to investigate the information that may be contained in a digital device are inappropriate tothe legal content of such investigative (search) action as the review of the subject. In this regard, it is considered appropriate to apply in this case a procedure for temporarily accessing such information by reading and copying it, which can be done to overcome the system of logical protection and to obtain the said access using specialized knowledge.

To solve the existing problem of possible destruction or complete waste of a material object during the examination, which creates obstacles in the implementation of the principles of parties' competitiveness and freedom in presenting their evidence to the court and in bringing to court their persuasiveness and direct examination of testimony, things and documents, it seems appropriate to predict the deposition of material evidence in case of potential impossibility of their submission in court proceedings due to their possible destruction or complete expenditure during pre-trial investigation.

In order to prevent loss of material evidence in the case of unlawful closure of criminal proceedings, it seems appropriate to clarify the provisions of Part 9 of Art. 100 of the CPC, stating that if an investigator or prosecutor concludes that there are grounds for closing a criminal proceeding, they should apply to the investigating judge for special confiscation and to resolve the issue of material evidence and documents before the ruling on the closure of criminal proceedings. At the same time, the appeal of the decision of the investigator or the prosecutor to close the criminal proceedings in accordance with the procedure provided by the CPC, shall suspend the entry into force of the decision of the investigating judge, delivered after the consideration of such request, and its execution.

Other defects of the Ukrainian criminal procedural legislation concerning the formation and resolution of physical evidence were also considered, and possible directions of regulatory adjustment were considered.

\section{SUMMARY}

The article analyzes some defects of legislative regulation in the aspect of the formation of material evidence in criminal proceedings. The discrepancy between the actions taken to investigate the information that may be contained in the digital device, with the legal content of such investigative (wanted) action as a search of the thing has been established. In view of this, it is appropriate to apply in this case the order of temporary access to such information by means of getting acknowledged with it and its copying that can be carried out to overcome the 
system of logical protection and obtain the specified access with the use of special knowledge. Also the author consider analyzes certain issues arising during the examination of material objects related to their possible destruction or complete consumption, as well as the study of court practice in this area. The author proposes to regulate the mechanism of expert examination of material objects in the case of a possible destruction in the examination process, and the procedure for handling of samples for comparative investigation after the examination. On the basis of the system analysis of the norms of the Ukrainian criminal procedural law, a comprehensive study is carried out on the procedure for deciding on the question of material evidences in pre-trial and judicial proceedings. Based on the normative provisions and the results of the generalization of judicial practice, conflicts and gaps in normative regulation were identified in the work and proposals were made on improving the criminal procedural legislation of Ukraine in this direction. This question is investigated under three points of view: de jure (formally, by law), de facto (in fact, as is the case in practice) and de lege ferenda (from the point of view of the law, the adoption of which is desirable).

\section{REFERENCES}

1. Loboiko L.M. (2014) Spivvidnoshennia danykh dosudovoho rozsliduvannia i dokaziv [Ratio of data of pre-trial investigation and evidence]. Pravo Ukrainy, no.10, pp. 82-88.

2. Shumylo M.Ye. (2013) Poniattia "dokazy" u kryminalnomu protsesualnomu kodeksi Ukrainy: sproba krytychnoho pereosmyslennia ideolohii normatyvnoi modeli [The notion of "evidence" in the criminal procedural code of Ukraine: an attempt to critically rethink the ideology of the normative model]. Visnyk Verkhovnoho Sudu Ukrainy, no. 2 (150), pp. 40-48.

3. Shylo O.H. (2013) Rechovi dokazy yak protsesualne dzherelo dokaziv [Physical evidence as a procedural source of evidence]. Visnyk prokuratury, no. 6 (144), pp. 76-83.

4. Kovalchuk S.O. (2016) Protsesualna forma rechovykh dokaziv u kryminalnomu provadzhenni [The procedural form of material evidence in criminal proceedings]. Pravo.ua, no. 3, pp. 157-164. Retrieved from: http://pravo.unesco-socio.in.ua/wpcontent/uploads/2016/11/Pravo_ua_2016_3-1.pdf (accessed 25.01.2020)

5. Morhun N.S. (2014) Tymchasove vyluchennia maina yak zakhid zabezpechennia kryminalnoho provadzhennia, shcho obmezhuie pravo vlasnosti [Temporary seizure of property as a measure to ensure the criminal proceedings, which restricts ownership]. Mytna sprava, no. № 3(2), pp. 318-323.

6. Smokov S., Lisnichenko D. (2015) Tymchasove vyluchennia ta aresht maina: dokaz chy zakhid zabezpechennia kryminalnoho provadzhennia [Temporary removal and seizure: evidence or a measure ensuring criminal proceedings]. Pravo Ukrainy, no. 5, pp. 163-170. 
7. Okonenko R.I. (2016) Elektronnye dokazatel'stva $i$ problemy obespecheniya prav grazhdan na zashchitu tajny lichnoj zhizni v ugolovnom processe: sravnitel'nyj analiz zakonodatel'stva Soedinennyh SHtatov Ameriki $i$ Rossijskoj Federacii [Electronic evidence and the problems of ensuring the rights of citizens to protect the secrets of their personal lives in criminal proceedings: a comparative analysis of the laws of the United States of America and the Russian Federation] (PhD Thesis), Moskva: Moskovskij gosudarstvennyj yuridicheskij universitet imeni O.E. Kutafina, 158 p.

8. Gambaryan A. S. Sudebnoe i notarial'noe deponirovanie pokazanij po iniciative advokata kak sredstvo garantirovaniya nezavisimosti advokata [Judicial and notarized deposition of evidence at the initiative of a lawyer as a means of guaranteeing the independence of a lawyer] (unpublished). Retrieved from: http://www.iuaj.net/node/1745 (accessed 25.01.2020)

9. Aleksandrov A.S., Kovtun N.N. Grachev S.A i drugie. Doktrinal'naya model' ugolovno-processual'nogo dokazatel'stvennogo prava Rossijskoj Federacii [Doctrinal model of criminal procedural evidence of the Russian Federation] (unpublished). Retrieved from: http://www.iuaj.net/node/1766 (accessed 25.01.2020)

10. Blazhivskyi Ye.M., Hroshevyi Yu.M., Domin Yu.M. ta in. (2012) Kryminalnyi protsesualnyi kodeks Ukrainy. Naukovo-praktychnyi komentar: u 2 t. T. 2 [The Criminal Procedure Code of Ukraine. Scientific and practical commentary: in 2 volumes. Vol. 2]. Kharkiv: Pravo, 664 p. (in Ukrainian)

11. Slovnyk ukrainskoi movy (1978): v 11 tomakh. T. 9, [Dictionary of the Ukrainian language: in 11 volumes. Vol. 9]. 916 p. Retrieved from: http://sum.in.ua/s/sumniv (accessed 25.01.2020)

12. Kovalchuk S.O. (2017) Vchennia pro rechovi dokazy u kryminalnomu protsesi: teoretyko-pravovi ta praktychni osnovy [The doctrine of physical evidence in criminal proceedings: theoretical, legal and practical basis]. Ivano-Frankivsk : Suprun V. P., 618 p. (in Ukrainian)

13. Kolodchyn V.V., Tumaniants A. R. (2016) Povnovazhennia prokurora $v$ sudovomu provadzhenni $u$ pershii instantsii [Powers of the prosecutor in court proceedings at first instance]. Kharkiv, TOV "Oberih", $228 \mathrm{p}$. (in Ukrainian)

\section{Information about the author: Iryna Krytska, PhD of Law,}

Assistant at the Department of Criminal Procedure, National Law University named after Yaroslav the Wise 77, Pushkinska str., Kharkiv, 61024, Ukraine ORCID ID: orcid.org/0000-0003-3676-4582 


\section{THE PRINCIPLE OF LEGALITY AS A FOUNDATION OF MODERN CIVIL SOCIETY}

\section{Alina Murtishcheva}

\section{INTRODUCTION}

Constitutional reform had profound political and legal consequences for Ukraine as a country trying to construct law-based state and to establish rule of law. Such state should declare the separation of state authority, the legal character of government, the legal protection of citizens from violations of their rights by state power, compensation for damage caused to them by state bodies.

The establishment of legal statehood and the practical implementation of the principle of the rule of law require the strict observance of the constitution and laws, first of all by public authorities and their officials. This is especially significant to the executive authority. The rule of law provides the basis for control over governmental actions, demanding from them to comply with the requirements of good governance. The experience of these bodies functioning demonstrates a constant tendency to increase power. Moreover, the examples of violations of the rules of the Basic Law by the power institutions have demonstrated the inability of some constitutional and legal institutions to effective regulation of public relations. That is why the issue of legal means, protecting constitutional legality, is of current importance.

In order ensure the rule of law and law-based state, there must be institutions that provide a restrictive connection between public authorities. Such restrictive institutions ensure the functioning of state authorities based on the division of power and constitutional legality. This is of significant importance for ensuring human and civil rights, as well as the implementation of the restrictive function of the constitution. Moreover, such institutions improve legal culture of officials, making a great impact on the development of civil society in general, because such society needs cooperation between citizens, non-government organizations and law-based and effective government.

\section{The notion of constitutional legality}

Researchers associate the emergence of legality with the rise of first bourgeois states in VII - VIII centuries, when legality became the principle of social and political system. The second reason was the adoption of constitutions, as it is considered that it is possible to talk about constitutional 
legality only if part of legality got its constitutional framework. Today, the principle of legality, traditionally considered a fundamental element of the rule of law, is known to the doctrines of the constitutional law of the English, French, German-speaking EU Member States (principle of legality, legalitätsprinzip, principe de la légalité), but there can be emphasis on various characteristics of the principle of legality.

For a general description of the principle of legality, one of the most respected researchers in the field of legal culture and justice professor Susan S. Silbey can be cited: "We use the word "legality" to refer to the meaning, sources of authority, and cultural practices that are recognized as legal, regardless of who employs them or for what ends. "Legality" is an analytic term rather than a socially approved state of affairs. In this rending, people may invoke and enact legality neither approved nor acknowledged by law".

Rather remarkable interpretation of the principle of legality is provided by the British doctrine and constitutional law of the Anglo-Saxon legal system countries. In general, British researchers make the point that the principle of legality states that the law should be clear, ascertainable and nonretrospective ${ }^{1}$.

Besides, the legality as principle is considered in broad and narrow terms. In a broad sense, the principle of legality means a broad set of constitutional regulations requiring that every power should be exercised only on the basis of a positive resolution ${ }^{2}$. In narrow sense of the principle of legality means a "clear statement principle" - a legislative body must speak unambiguously if it wants to compromise liberty ${ }^{3}$. Moreover "the courts should be slow to impute to Parliament an intention to override established rights and principles where that is not clearly spelt out"4. This requirement is often called minimalist, because "it left undecided the larger questions about the meaning of the Constitution". At the same time this principle protects human rights, because in the absence of clear prescriptions of the law, the courts will not

${ }^{1}$ The Government and the Principle of Legality. URL: https://www.lawteacher.net/free-lawessays/administrative-law/the-government-and-the-principle-of-legality-administrative-lawessay.php\#ftn9

${ }^{2}$ Lim B. (2013) The Normativity of the Principle of Legality. Melbourne University Law Review, Vol. 37:372. P. 373.

${ }^{3}$ Sunstein C. R. (2005) Radicals in Robes: why extreme right-wing courts are wrong for America, New York: Basic Books. P. 132.

${ }^{4}$ Sales P. (2008) A comparison of the principle of legality and section 3 of the Human Rights Act 1998. Statute law society conference. Belfast. URL: http://www.statutelawsociety.co.uk/wpcontent/uploads/2014/01/A_comparison_of_the_principle_of_legality_and_section_3_of_the_Hu man_Rights_Act_1998._Mr_Justice_Sales.pdf

${ }^{5}$ Sunstein C. R. (2005) Radicals in Robes: why extreme right-wing courts are wrong for America, New York: Basic Books. P. 132. 
impute to the legislator the intention to limit the fundamental rights established by common law. And the law must be interpreted in such a way as to minimize interference with the sphere of rights. All things considered, this approach focuses on the importance of the principle of legality for respect for human rights and freedoms.

The modern science of constitutional law in the United Kingdom discuss the question of limiting the principle of parliamentary sovereignty by the principle of legality as a constituent of the rule of law. For example, Trevor R.S. Allan, a professor at the University of Cambridge Law School, said that formally, the doctrine of absolute parliamentary sovereignty not only sanctions restrictions on constitutional rights but can theoretically abolish any requirement of the rule of law. In practice, the courts, while protecting fundamental rights, interpret the legislation and allow the limitation of parliamentary legislative supremacy. However, it is believed that "any limitation of the doctrine of legislative supremacy, necessary to sustain the rule of law, is, therefore, already implicit in the concepts of law and legality on which the "unwritten" Constitution of Great Britain is constructed. In short, no new "qualification" (or judicial amendment) of existing constitutional law is needed ${ }^{6}$. It can be concluded that the principle of constitutional legality has the potential of limiting the power by law, and the judicial branch is used as an instrument of such restriction, as will be discussed later.

Consideration of the levels of application of the principle of legality can be regarded as the achievement of the German constitutionalists. For example, Professor Anne Peters noted that the principle of legality (German, gesetzmäßigkeit) today is developed at two "levels" of law (domestic and international). So this principle can be interpreted as a multi-level, transnational or global principle. The basic nature (material importance) of the principle of legality confirms its characteristic as belonging to a global constitutional law ${ }^{7}$.

Austrian constitutional law has rather unique and interesting look at the significance of the principles of constitutional law in general. For example, according to Professor Theo Öhlinger's opinion, constitutional law is bimodal: its basic principles are understood as "super-constitutional" law,

${ }^{6}$ Allan T.R.S. (2011) Questions of legality and legitimacy: Form and substance in British constitutionalism. International Journal of Constitutional Law, vol. 9, Issue 1, pp. 155-162. URL: https://doi.org/10.1093/icon/mor017

7 Peters A. (2016) Legality as a Principle of Global Constitutional Law. European Convention on Human Rights and the Crimes of the Past. ECtHR Conference. URL: http://www.mpil.de/files/pdf4/Anne_Peters_Abstract_Legality_as_a_Principle_of_Global_Consti tutional_Law1.pdf 
which is higher than "ordinary" or "traditional" constitutional law. There are, under this approach, the two-level constitutional principles, in particular, the principle of legality. This peculiarity develops within the national legal system and is implemented to emphasize fundamentality and importance of such principles for the formation and development of the state.

Attention should also be paid to reviewing the constitutional principle of legality by the countries of the former socialist camp, since their understanding of this principle is close to Ukrainian and has similar historical background. For example, Romanian authors consider that the principle of legality is one of those constitutional principles that ensure the rule of law, along with the principle of separation of powers, the principle of protection of human rights and freedoms, the principle of equality of rights and responsibilities of all citizens, the principle of political diversity, the principle of free access to justice, the principle of the independence of the judiciary ${ }^{8}$.

The principle of legality requires all subjects of law, natural and legal persons, citizens and foreigners, public authorities, private organizations to comply with the law and other normative acts based on it, participating in any public relations. This state of affairs is guaranteed with court sanctions. Another understanding of the principle of legality is also offered by Romanian researchers: in addition to requiring all subjects of law to comply with legal rules he currently in force, the principle of legality also implies respect for the hierarchy of legal norms and their organization into a pyramid system ${ }^{9}$.

Bulgarian professor Tanchev Evgeni examines legality through the prism of a lack of legitimacy that is general characteristic of young democracy countries. He suggests that if the legal system is legitimate, then legality can become the best protective principle of a legitimate constitutional system, can ensure confidence in public authorities and support a democratic system ${ }^{10}$. It can be said that ensuring legitimacy in the activities of government institutions will help to reduce the low level of public trust in public authorities and local self-government.

Attention should be given to the difference between notions "constitutional legality" and "constitutional legitimacy". The main peculiarity

${ }^{8}$ Stoian A., Drăghici T. (2015) The principle of legality, principle of public law. Knowledgebased organization. International conference. Vol. XXI, No 2. P. 512-515.

${ }^{9}$ Stefannoaia M. The Role of the Constitutional Court of Romania in the Constitutionalization of Criminal Law. Drepturi și libertăți fundamentale: dimensiune istorică și constituțională - in memoriam prof. Univ. dr. Grigore Theodoru - 1919-2015. Conferința națională. URL: $\mathrm{http} / / /$ revista.universuljuridic.ro/supliment/role-constitutional-court-romania-

constitutionalization-criminal-law-2/

${ }^{10}$ Tanchev E. Constitutional safeguards of legality and legitimacy. Report to the Civil Service Forum at EIPA in Maastricht. Openness and Transparency in Governance: Challenges and Opportunities (NISPAcee 2000) / Ed. M. Kelly, P. 74. 
of constitutional legitimacy is that it is "a virtue rooted in a system of belief: the acceptance that an exercise in power is justified and therefore authorized, either implicitly or explicitly, by society at large". Moreover, it is stressed that "an illegal action may be legitimate in the eyes of the people, and conversely, simply because an action is legal does not always imply that it is legitimate" 11 . Taking into consideration that so called "young democracies", for instance, Ukraine, are characterized as countries with a lack of both legitimacy and legality and not developed civil society we strongly believe that constitutional legislation should involve the principle of constitutional legality as binding first of all supreme authorities of the state.

As for Ukrainian constitutional law science it can be noted that the study of legality was characterized as fragmented for a long time, its substantive characteristics were not revealed. The main reason for this state of affairs, in particular, was the analysis of this category in the system of socialist legality. At the same time it seems that there were some positive recommendations developed in early studies. For instance, putting the question of correlation between socialist and constitutional legality and determination the latter as basic category. The other recommendation is the proper implementation of laws by all bodies of state power, officials and citizens ${ }^{12}$. This meant recognizing public authorities as subjects whose activities (not only law enforcement) should be based on the principle of constitutional legality.

Attention is also should be drawn to distinguishing the principle of legality and the principle of constitutional legality as a main constituent of legality. The modern constitutional law science can be characterized by the lack of unity of scientific thought on aspects of constitutional legality. Although today the complex nature of this category and the scientific search for the main features that characterize its content are recognized. This complex approach fully corresponds to the experience of the democratic countries of Europe.

Several scientific views on the notion "constitutional legality" can be described. Firstly, constitutional legality considered to be a system of real existing law, which contemplates the existence of the constitution, its central role in the legal system of state, its direct application throughout the state, protection of its rules ${ }^{13}$, its correct application by authorities and officials ${ }^{14}$.

11 Chau, Brian (2012) Constitutional Legitimacy: An Analysis under Max Weber's Traditional Sources of Authority. URL: http://dx.doi.org/10.2139/ssrn.2192172

12 Problemy sotsialisticheskoy zakonnosti na sovremennom etape razvitiya sovetskogo gosudarstva: mezhvuz. nauch. konf. Tez. dokl. (okt. 1968 g.) / otv. red. M. I. Baru ; red. kol. V.A. Barakhtyan i dr. Khar'kov: Khar'k. yurid. in-t, 1968. p. 4 (in Russian).

${ }^{13}$ Krusjan A. (2012) Konstytucijna zakonnistj: pravova doktryna ta praktyka zabezpechennja i zakhystu v Ukrajini. Mytna sprava. № 1 (79). pp. 4-5. (in Ukrainian) 
Secondly it is considered as general requirement that reflects the necessity for the legitimate behavior or any activity of all subjects of constitutional legal relations ${ }^{15}$. Furthermore, some scientists call constitutional legality one of the methods of exercising state power, the essence of which is to create the necessary legislative acts, the mechanism of their implementation and appropriate control over their implementation by the state ${ }^{16}$. Others consider it as a special aspect of the concept of "legality", which demands compliance all of laws with the constitution of the country ${ }^{17}$. And lastly, the constitutional legality is considered as the type of legality, which is expressed in the legal nature of the constitution itself, its supremacy, the direct effect of the norms and principles of the constitution and in the institution of constitutional jurisdiction ${ }^{18}$.

To sum up it should be said that the constitutional legality has complex nature. This phenomenon covers various fields of state and public life, and therefore it can be considered as a principle, method and regime. Compliance with the constitution, laws, other legal acts, addressed to all bodies of state power and local self-government, officials, citizens and their associations, can be considered as its basic requirement. The constitutional legality covers not only implementation, application of legal rules, but also lawmaking, and that is why it is a complex category. The constitutional legality, in a static aspect, is the basis of the constitutional order of the country, it determines the legal nature of the activity of subjects of constitutional legal relations, and in the dynamic aspect it is a method and real manner of functioning of public authorities. This understanding allows us to evaluate both the product of rulemaking and the activity of the subjects of constitutional relations.

This peculiarity also allows to define such a feature of constitutional legality as the impact of its requirements, first of all, on the activities of public authorities. That is why the constitutional legality is often defined as a means of restriction of the power, which influence the effectiveness of the system of checks and balances. The legality in the state in general depends on the functioning of public authorities in the mode of constitutional legality.

${ }^{14}$ Jurydyčna encyklopedija: v 6 t. (2001) / redkol.: Ju. S. Šemčušenko. Kyjiv: "Ukr. encykl." T. 3: K-M. p. 288. (in Ukrainian)

${ }^{15}$ Tkachenko Ju. V. Konstytucijna zakonnistj jak pryncyp konstytucijnogho ladu. Forum prava. 2010. № 4. pp. 875-883. URL: http://nbuv.gov.ua/UJRN/FP_index.htm_2010_4_141 (in Ukrainian)

${ }^{16}$ Parxomenko N.M. (2012) Konstytucijna zakonnist' jak meta, vymoha ta pravovyj režym: teoretyčni aspekty. Al'manax prava. Vyp. 3. pp. 38-41. (in Ukrainian)

${ }^{17}$ Арутюнян Г.Г., Баглай М. В. Конституционное право: Энциклопедический словарь. Москва: Норма, 2006. С. 151.

${ }^{18}$ Skakun O. F. (2007) Teoryja hosudarstva y prava (эncyklopedyčeskyj kurs): učebnyk. Xar'kov: Эspada, 2007. pp. 711-712. (in Russian) 
Moreover, the process of civil society formation and functioning depends greatly on such a legal functioning. That is why the constitutional legality is one of important factor able to ensure civil society and to guarantee the rule of law.

Considering foreign practice one should said that in general it testifies to the wider use of the term "legality" - today it is incorporated in the Constitutions of more than one and a half hundred countries. For example, it was directly fixed in the Federal Constitutional Law of the Austrian Republic (Article 18, part 1): "The entire public administration shall be based on law"19; in Basic Law for the Federal Republic of Germany (Article 20, part 3): "The legislature shall be bound by the constitutional order, the executive and the judiciary by law and justice" 20 ; in Constitution of the Portuguese Republic (Article 3, part 2 "Sovereignty and legality"): "The state is subject to the Constitution and is based on democratic legality" ${ }^{21}$; in Constitution of Romania (Article 1, part 1): "In Romania, the observance of the Constitution, its supremacy and the laws shall be mandatory",22; in The Instrument of Government of Sweden (Article 1 chapter 1): "Public power is exercised under the law",23.

In Greece, the principle of legality is incorporated in a number of constitutional articles, which can be represented in the form of a requirement that the actions of the executive should comply with the norms of law at the level of the Constitution and laws ${ }^{24}$. Consequently, there is the emphasis on applying this principle to the actions of the executive branch. At the same time, in France, the principle of legality (French le principe de légalité) is not directly expressed in the text of the Constitution, but is applied as a general principle of law. There is the same approach to the application of the principle of legality (Dutch legaliteitsbeginsel) in the Netherlands.

\section{The means of ensuring the constitutional legality}

The constitutional legality considered to be a kind of "super-principle", which is crucial for all constitutional norms. It also corresponds to the "spirit"

19 Federal Constitutional Law of 10 November 1920. URL: https://www.ris.bka.gv.at/ Dokumente/Erv/ERV_1930_1/ERV_1930_1.pdf

${ }^{20}$ Basic Law for the Federal Republic of Germany. 23 May 1949. Last ammended on 12 July 2017. URL: https://www.btg-bestellservice.de/pdf/80201000.pdf

${ }^{21}$ Constitution of the Portuguese Republic of 21 August 1991. URL: http://www.en.parlamento.pt/ Legislation/CRP/Constitution7th.pdf

22 Constitution of Romania of 21 Novenber 1991. URL: http://www.cdep.ro/pls/ dic/site.page? $\mathrm{id}=371$

23 The Instrument of Government. URL: http://www.riksdagen.se/en/SysSiteAssets/07.dokument--lagar/the-instrument-of-government-2015.pdf/

${ }^{24}$ Brandhof J. C. E. van den. (2004) Constitutional Law of 15 EU Member States, Kluwer, P. 401. 
of the Basic Law of any democratic country and constitutional state, and therefore may not be expressed in text, which poses a serious threat of its violation by the authorities. As the German constitutionalist Ernst-Wolfgang Böckenförde remarked, constitutional legality is not created by itself, the practice of legality is based on political conditions which it cannot guarantee" 25 . Therefore, there should be specific constitutional institutions aimed at ensuring constitutional legality that will allow making a system of "principle - guaranteeing institution - regime". The absence of such institutions, special means as a response to violations of constitutional legality, will not let the latest to be a mode of functioning of public authority and will lead to the loss of value of the principle legality as a whole.

Judicial constitutional control is considered to be a traditional way of ensuring and protecting constitutional legality. Constitutional Court as a separate body is called the "watchdog of the Constitution in a given country, and as a protector of the constitutionality, legality, and the citizens' freedoms and rights within the national legal system" $"$.

The development of parliamentarism cause the need to control the activity of the legislator. However, the institution of constitutional control met with opposition, representing by parliamentary sovereignty as a foundation of parliamentarism. One of the consequences of the historical recognition of the sovereignty and supremacy of parliaments in European states was the prohibition of judicial review of parliamentary acts for constitutionality. Today, the so-called principle of "legislative supremacy" is criticized by researchers ${ }^{27}$.

The main reason against is inappropriateness of defining relations between branches of power in terms of rivalry and the superiority of one government body over another. However, the idea of prohibiting the judicial control over parliamentary acts, although not widespread, remains embodied in some countries. For example, according to Article 120 of the Constitution of the Kingdom of the Netherlands "The constitutionality of Acts of Parliament and treaties shall not be reviewed by the courts" 28 .

25 Böckenförde E-W. (1991) State, society, liberty: studies in political theory and constitutional law. New York: Berg. P. 171.

${ }^{26}$ Karakamisheva-Jovanovska T. (2010) Different Models for protection of constitutionality, legality and independence of constitutional court of the Republic of Macedonia. Venice Commission. URL: http://www.venice.coe.int/WCCJ/Rio/Papers/MKD_Karakamiseva_E.pdf

${ }^{27}$ Porter J. C. A. (2013) Constitutional review in the Netherlands: a joint responsibility. Utrecht Law Review. 9 (2), P. 89.

${ }^{28}$ The Constitution of the Kingdom of the Netherlands. URL: https://www.government.nl/ documents/regulations/2012/10/18/the-constitution-of-the-kingdom-of-the-netherlands-2008 
The influence of the principle of legislative supremacy is also clear in other parliamentary monarchies. The Constitutional Act of Denmark of $1953^{29}$ makes no mention of the right of courts to exercise constitutional control. In practice, such a power exists, however, governed by a constitutional custom based on the constitutional principle of separation of powers. This custom was formed as early as the 1920s, when the Supreme Court expressed a legal position on the possibility of judicial review of laws for compliance with the Constitution $^{30}$. Therefore, the present day constitutional control is exercised by courts of general jurisdiction, however, it is only a matter of reviewing the laws for compliance with the constitution, as well as observance procedural rules while adopting them.

Nearly the same situation concerns countries with a republican form of government, which, although institutionalized judicial constitutional control, but also restricted it by providing the power to check only parliamentary acts. For example, the Supreme Special Court of Greece court can only consider the constitutionality of laws, not acts of the executive branch (article 100 of the The Constitution of Greece ${ }^{31}$ ). In Romania, the question of the constitutionality of governmental acts is also impossible, because according to the Constitutional Court of Romania's judgment of 371 April 13, 2010, these acts can only be the subject of review of lawfulness in the order of administrative justice, because they are administrative by nature ${ }^{32}$. According to Article 149 of the Constitution of the Republic of Bulgaria, governmental acts may not be subject to judicial constitutional control also. However, acts of the Council of Ministers and Ministers may be declared illegal in the administrative procedure of the Supreme Administrative Court of Bulgaria (part 2, Article 125 of the Constitution ${ }^{33}$ ). As a result, the only means ensuring legality of the supreme executive body activities, but not a constitution legality directly, is the institution of administrative justice.

There is different trend in other EU countries, where a specialized body is given a considerable amount of authority within the framework of the Austrian model of constitutional control. Within this model a huge amount of

29 The Constitutional Act of Denmark. URL: http://www.thedanishparliament.dk/ Publications/The_Constitutional_Act_of_Denmark.aspx

${ }^{30}$ Isaev M. A. Mekhanizm gosudarstvennoy vlasti v stranakh Skandinavii. Konstitutsionnopravovye aspekty: dis. ... d-ra yurid. nauk. Moskva, 2004. 371 s. (in Russian)

31 The Constitution of Greece. URL: http://www.hellenicparliament.gr/UserFiles/f3c70a237696-49db-9148-f24dce6a27c8/001-156\%20aggliko.pdf

${ }^{32}$ Rule of law, human rights and judicial control of power (2017) / ed. Rainer A., MartinezEstay J. I. 1-st ed. Springer. 446 pp. 35-36.

${ }_{33}$ Constitution of the Republic of Bulgaria. URL: https://www.wipo.int/edocs/lexdocs/ laws/en/bg/bg033en.pdf 
EU member States establish the review of not only parliamentary, but also of governmental acts (for instance, Article 102 of the Constitution of the Republic of Lithuania ${ }^{34}$, Article 125 of Constitution of the Slovak Republic ${ }^{35}$ ). One more group of countries established review for constitutionality of all acts of public authorities regardless of the branch of power (for instance, Article 188 of the Constitution of the Republic of Poland ${ }^{36}$, Article 153 of Constitution of the Republic of Slovenia ${ }^{37}$, Article 125 of Constitution of the Republic of Croatia $^{38}$ ).

The extension of the Constitutional Tribunal of the Republic of Poland powers caused by constitutional provision on the possibility of reviewing the conformity of the constitution, ratified international treaties and the laws of the act of any central body of the state (Article 188 of the Constitution ${ }^{39}$ ). The extensive powers of the Constitutional Tribunal in the field of reviewing the constitutionality and legality of regulatory acts are nevertheless balanced by the inability of the Constitutional Tribunal to initiate such reviews at its own discretion.

As a conclusion it should be mentioned that principle of parliamentary sovereignty, which has historically come with the change of absolute monarchies in Europe, still has a significant impact on the development of constitutional justice. For instance, there is prohibition on constitutional control in general in some countries. Nevertheless, due to the development of public relations, the restriction of parliamentary sovereignty and judicial constitutional control is becoming necessary to state-making processes. However, it should be also noted that the issue of control over governmental acts owing to the need to find a balance between the legislative and judicial branches of power in this case is too early to raise in the individual states. It is stated that control of legality of the governmental act is sufficient. Although the significance of executive branch of power is doubtless.

${ }^{34}$ The Constitution of the Republic of Lithuania. URL: http://www3.1rs.lt/home/Konstitucija/ Constitution.htm

35 Constitution of the Slovak Republic of 1 September 1992. URL: https://www.prezident.sk/upload-files/46422.pdf

${ }^{36}$ The Constitution of the Republic of Poland. Dziennik Ustaw No. 78, item 483. URL: http://www.sejm.gov.pl/prawo/konst/angielski/kon1.htm

37 Constitution of the Republic of Slovenia of 23 December 1991. Official Gazette of the Republic of Slovenia Nos. 33/91-I, 42/97, 66/2000, 24/03, 69/04, 68/06, and 47/13. URL: https://www.dz-rs.si/wps/portal/en/Home/PoliticniSistem/UstavaRepublikeSlovenije

38 Constitution of the Republic of Croatia NN 85/2010, 09.07.2010. URL: https://www.wipo.int/edocs/lexdocs/laws/en/hr/hr060en.pdf

${ }^{39}$ The Constitution of the Republic of Poland. Dziennik Ustaw No. 78, item 483. URL: http://www.sejm.gov.pl/prawo/konst/angielski/kon1.htm 
In the modern world the role of the highest executive authorities is increasing. According to the Jean Blondel "The executive is manifestly a focal point, if not the focal point of political life. This remains true even if doubts are sometimes expressed about the ability of executives to affect markedly the course of events, let alone alter drastically the social and economic structure of their country. At least they have, more than any other body, an opportunity to shape society; it is indeed their function to do so" $"$. The supreme body of the executive power determines the directions of policy within "the framework set by the legislation enacted by parliament, and is at the head of the administrative apparatus of the

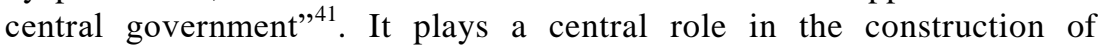
national economy, contribute to police-making at national, regional and international levels, etc. The role of governments may be exemplified by the expression: "government refers to the body or bodies responsible for governing the State"42 that is also laid down at the constitutional level (for instance, in article 6 Chapter 1 of the Instrument of Government of Sweden: "The Government governs the Realm"43).

As a consequence there should be another means how to protect legality of executive branch of power. One more institution considered to be an effective means of ensuring legality of the public authority is constitutional liability.

Ensuring the balance of state power with the guarantee of democratic foundations of the political system and the regime of constitutional legality make the special attention to the issues of the effectiveness of the institution of the constitutional liability of the government. Being an important element in the system of checks and balances, this institute is in the field of dynamic political and legal relations, increasingly demonstrating its flexibility and adaptability. The complex constitutional modernization, initiated in Ukraine in the context of obvious intensification the European integration processes, actualizes the improvement of the existing and development of new mechanisms of constitutional liability on the basis of a modern doctrinal basis. Moreover, such mechanism should take into consideration the latest achievements and tendencies of development of the governmental liability institution.

\footnotetext{
${ }^{40}$ Encyclopedia of Government and Politics (1992) / Ed. by M. Hawkesworth and M. Kogan. London, New York. P. 267.

${ }^{41}$ Brandhof J.C.E. van den. (2004) Constitutional Law of 15 EU Member States, Kluwer, P. 512.

42 The Machinery of Government. Structure and functions of Government. May 2003, Department of Public service and Administration. URL: http://www.dpsa.gov.za/dpsa2g/ documents $/ \mathrm{lkm} / \mathrm{mog}$.pdf

43 The Instrument of Government. URL: http://www.riksdagen.se/en/SysSiteAssets/07.dokument--lagar/the-instrument-of-government-2015.pdf/
} 
Constitutional liability can be characterized as defined by the constitution of the state, guaranteed by state sanctions the constitutional obligation of the highest executive authorityи for the proper performance of its constitutional functions and duties, as well as the condemnation and coercive influence in case of improper performance of such functions and duties, as well as in the case of resolving constitutional conflicts.

The main purpose of constitutional liability is to protect the constitution and the regime of constitutional legality. The importance of the constitutional liability of the government for ensuring constitutional legality was outlined by Polish professors Wojciech Sokolewicz and Sabina Grabowska: firstly, this institution ensures observe of the constitution by officials who perform the most important functions in the state. This means not only abstaining from violating constitutional provisions, but also committing actions aimed at implementing constitutional norms. Secondly, it guarantees that the subjects of constitutional liability includes the principles of legality and the rule of law in their activities ${ }^{44}$.

There are different forms of governmental liability. Firstly, collective and individual forms, which differs according to the subject. Secondly, parliamentary liability (the collective liability of the government and the individual liability of the prime minister and / or ministers), liability to the head of state, to a specially created or constitutional court. The instance of such liability may be represented by the Parliament, the Head of State and a specially created or constitutional court.

The transformation processes of constitutional liability of the government institution have affected the role of the instances of liability in European states, in particular, of the head of state. His significance is more of an exception than a general rule. For instance the head of state is not independent and acts in a certain "tandem" with the prime minister in the mechanism of individual liability of ministers in Germany. According to Part 1 of Art. 64 of the Basic Law of Germany "Federal ministers are appointed and dismissed by the Federal President at the proposal of the Federal Chancellor"45. The federal president is obliged to appoint and dismiss a person proposed by the Federal Chancellor, the proposals of the latter are beyond doubt ${ }^{46}$. This rule exist due to the "Chancellor principle" (German Kanzlerprinzip).

${ }^{44}$ Sokolewicz W. Art. 156. (2007) Konstytucja Rzeczypospolitej Polskiej. Komentarz. Volume Second / Ed. L. Garlicki. Warszawa: Wydawnictwo Sejmowe, pp. 2-3.

${ }^{45}$ Basic Law for the Federal Republic of Germany. 23 May 1949. Last ammended on 12 July 2017. URL: https://www.btg-bestellservice.de/pdf/80201000.pdf

${ }^{46}$ Fisher J., Kaiser A. (2011) Wie gewonnen, so zerronnen? Selektions- und Deselektionsmechanismen in den Karrieren deutscher Bundesminister. Politische Vierteljahresschrift Sonderheft. Sonderheft 44/2010, "Politik als Beruf". S. 195-196. 
Moreover, since the control powers often are not used by the head of state. For instance, the Federal President of Austria theoretically can dismiss the Federal Chancellor or the Federal government on his own, but in practice he does not use this power according to so called "renunciation of role" (German "Rollenverzicht"). It means the refusal to take an active part in daily politics, use discretional powers, especially in matters of appointment and dismissal of chancellors and ministers. Therefore, the institution of constitutional liability, its forms and realization is a case of major importance for modern European countries.

\section{CONCLUSIONS}

Summing up, the following references can be made. Today formation and active development of civil society as a system of social institutions (state, family, local self-government, public, religious organizations, political parties, the media etc.), as well as relations between them (political, economic, social, cultural etc.), undoubtedly, takes place. Therefore, it is also necessary to pay attention to the role of state authorities in this process. Since the main aim of civil society is to ensure the rights and freedoms of man and citizen, it is necessary to create certain restrictive institutions for the purpose to ensure state authority functioning in accordance with the principle of constitutional legality.

The notion of "legality" is one of the most important in the constitutional doctrine and constitutional legislation of European countries. Legality is the most important component of the rule of law as a key idea of the functioning of the state and society. Given the obvious importance of this notion, the question of appropriate means aimed at ensuring and guaranteeing the rule of law in a modern state arises. This issue is especially important for the countries of young democracy, where the legal culture of citizens as well as officials does not reach a high level.

The traditional means of ensuring constitutional legality is constitutional review or control. However, due to historical reasons, this institution is not always able to respond to illegal or unconstitutional actions of the executive branch of state power. Therefore, the functioning of the institution of constitutional liability of the government becomes important. This institution through various forms and instances can provide control and enforcement of government actions in accordance with the law.

\section{SUMMARY}

The paper looks at researches dealing with the problem of the principle of legality and its main part - constitutional legality. Various views of European, American and Ukrainian of the experts in the field of constitutional law on the notion of legality are considered. Much attention is given to the interpretation of the principle of legality considered in 
British doctrine. It is also established that constitutional legality is a complex category covering not only implementation, application of legal rules, but also lawmaking.

The paper also gives valuable information on the constitutional and legal regulation of the principle legality. Besides, the paper is concerned with the means of ensuring constitutional legality, such as constitutional control and constitutional liability. It is stressed that constitutional liability of bodies of state power can be an effective measure, especially taking into consideration that many countries establish the possibility to oversight only legality of governmental statutory acts. The general description of the constitutional liability is given. Protection of constitution and regime of constitutional legality is defined as a main purpose of constitutional liability.

\section{REFERENCES}

1. Allan T.R.S. (2011) Questions of legality and legitimacy: Form and substance in British constitutionalism. International Journal of Constitutional Law, vol. 9, Issue 1, pp. 155-162. URL: https://doi.org/10.1093/icon/mor017

2. Basic Law for the Federal Republic of Germany. 23 May 1949. Last ammended on 12 July 2017. URL: https://www.btg-bestellservice.de/ pdf/80201000.pdf

3. Böckenförde E-W. (1991) State, society, liberty: studies in political theory and constitutional law. New York: Berg. 272 p.

4. Brandhof J.C.E. van den. (2004) Constitutional Law of 15 EU Member States, Kluwer, 949 p.

5. Chau, Brian (2012) Constitutional Legitimacy: An Analysis under Max Weber's Traditional Sources of Authority. URL: http://dx.doi.org/10.2139/ ssrn. 2192172

6. Constitution of Romania of 21 November 1991. URL: http://www.cdep.ro/pls/dic/site.page?id=371

7. Constitution of the Portuguese Republic of 21 August 1991. URL: http://www.en.parlamento.pt/Legislation/CRP/Constitution7th.pdf

8. Constitution of The Republic of Bulgaria. URL: https://www.wipo.int/ edocs/lexdocs/laws/en/bg/bg033en.pdf

9. Constitution of the Republic of Croatia NN 85/2010, 09.07.2010. URL: https://www.wipo.int/edocs/lexdocs/laws/en/hr/hr060en.pdf

10. Constitution of the Republic of Slovenia of 23 December 1991. Official Gazette of the Republic of Slovenia Nos. 33/91-I, 42/97, 66/2000, 24/03, 69/04, 68/06, and 47/13. URL: https://www.dz-rs.si/wps/portal/en/ Home/PoliticniSistem/UstavaRepublikeSlovenije

11. Constitution of the Slovak Republic of 1 September 1992. URL: https://www.prezident.sk/upload-files/46422.pdf 
12. Encyclopedia of Government and Politics (1992) / Ed. by M. Hawkesworth and M. Kogan. London, New York. 637 p.

13. Federal Constitutional Law of 10 November 1920. URL: https://www.ris.bka.gv.at/Dokumente/Erv/ERV_1930_1/ERV_1930_1.pdf

14. Fisher J., Kaiser A. (2011) Wie gewonnen, so zerronnen? Selektionsund Deselektionsmechanismen in den Karrieren deutscher Bundesminister. Politische Vierteljahresschrift Sonderheft. Sonderheft 44/2010, "Politik als Beruf". S. 192-212.

15. Isaev M.A. Mekhanizm gosudarstvennoy vlasti v stranakh Skandinavii. Konstitutsionno-pravovye aspekty: dis. ... d-ra yurid. nauk. Moskva, 2004. 371 s. (in Russian)

16. Jurydyčna encyklopedija: v 6 t. (2001) / redkol.: Ju. S. Šemčušenko. Kyjiv: “Ukr. encykl”. T. 3: K-M. pp 610. (in Ukrainian)

17. Karakamisheva-Jovanovska T. (2010) Different Models for protection of constitutionality, legality and independence of constitutional court of the Republic of Macedonia. Venice Commission. URL: http://www.venice.coe.int/WCCJ/Rio/Papers/MKD_Karakamiseva_E.pdf

18. Krusjan A. (2012) Konstytucijna zakonnistj: pravova doktryna ta praktyka zabezpechennja i zakhystu v Ukrajini. Mytna sprava. № 1 (79). pp. 4-5. (in Ukrainian)

19. Lim B. (2013) The Normativity of the Principle of Legality. Melbourne University Law Review, Vol. 37:372. pp. 372-414.

20. Parxomenko N.M. (2012) Konstytucijna zakonnist' jak meta, vymoha ta pravovyj režym: teoretyčni aspekty. Al'manax prava. Vyp. 3. pp. 38-41. (in Ukrainian)

21. Peters A. (2016) Legality as a Principle of Global Constitutional Law. European Convention on Human Rights and the Crimes of the Past. ECtHR Conference. URL: http://www.mpil.de/files/pdf4/Anne_Peters_Abstract_ Legality_as_a_Principle_of_Global_Constitutional_Law1.pdf

22. Porter J.C.A. (2013) Constitutional review in the Netherlands: a joint responsibility. Utrecht Law Review. 9 (2), pp. 89-105.

23. Problemy sotsialisticheskoy zakonnosti na sovremennom etape razvitiya sovetskogo gosudarstva: mezhvuz. nauch. konf. Tez. dokl. (okt. 1968 g.) / otv. red. M.I. Baru ; red. kol. V.A. Barakhtyan i dr. Khar'kov: Khar'k. yurid. in-t, 1968. 291 p. (in Russian)

24. Rule of law, human rights and judicial control of power (2017) / ed. Rainer A., Martinez-Estay J.I. 1-st ed. Springer. 446 p.

25. Sales P. (2008) A comparison of the principle of legality and section 3 of the Human Rights Act 1998. Statute law society conference. Belfast. URL: http://www.statutelawsociety.co.uk/wp-content/uploads/2014/01/A_ 
comparison_of_the_principle_of_legality_and_section_3_of_the_Human_Rig hts_Act_1998._Mr_Justice_Sales.pdf

26. Skakun O.F. (2007) Teoryja hosudarstva y prava (эncyklopedyčeskyj kurs): učebnyk. Xar'kov: Эspada, 2007. 840 p. (in Russian)

27. Sokolewicz W. Art. 156. (2007) Konstytucja Rzeczypospolitej Polskiej. Komentarz. Volume Second / Ed.L. Garlicki. Warszawa: Wydawnictwo Sejmowe, pp. 1-32.

28. Stefannoaia M. The Role of the Constitutional Court of Romania in the Constitutionalization of Criminal Law. Drepturi și libertăți fundamentale: dimensiune istorică și constituțională - in memoriam prof. Univ. dr. Grigore Theodoru - 1919-2015. Conferința națională. URL: $\mathrm{http} / / /$ revista.universuljuridic.ro/supliment/role-constitutional-court-romaniaconstitutionalization-criminal-law-2/

29. Stoian A., Drăghici T. (2015) The principle of legality, principle of public law. Knowledge-based organization. International conference. Vol. XXI, No 2. P. 512-515.

30. Sunstein C. R. (2005) Radicals in Robes: why extreme right-wing courts are wrong for America, New York: Basic Books, XV, 281 pp.

31. Tanchev E. Constitutional safeguards of legality and legitimacy. Report to the Civil Service Forum at EIPA in Maastricht. Openness and Transparency in Governance: Challenges and Opportunities (NISPAcee 2000) / Ed. M. Kelly. pp. 72-99.

32. The Constitution of Greece. URL: http://www.hellenicparliament.gr/ UserFiles/f3c70a23-7696-49db-9148-f24dce6a27c8/001-156\%20aggliko.pdf

33. The Constitution of the Kingdom of the Netherlands. URL: https://www.government.nl/documents/regulations/2012/10/18/the-

constitution-of-the-kingdom-of-the-netherlands-2008

34. The Constitution of the Republic of Lithuania. URL: http://www3.lrs.lt/home/Konstitucija/Constitution.htm

35. The Constitution of the Republic of Poland. Dziennik Ustaw No. 78, item 483. URL: http://www.sejm.gov.pl/prawo/konst/angielski/kon1.htm

36. The Constitutional Act of Denmark. URL: http://www.thedanishparliament.dk/Publications/The_Constitutional_Act_of_ Denmark.aspx

37. The Government and the Principle of Legality. URL: https://www.lawteacher.net/free-law-essays/administrative-law/thegovernment-and-the-principle-of-legality-administrative-law-essay.php\#ftn9

38. The Instrument of Government. URL: http://www.riksdagen.se/en/ SysSiteAssets/07.-dokument--lagar/the-instrument-of-government-2015.pdf/ 
39. Tkachenko Ju. V. Konstytucijna zakonnistj jak pryncyp konstytucijnogho ladu. Forum prava. 2010. № 4. pp. 875-883. URL: http://nbuv.gov.ua/UJRN/FP_index.htm_2010_4_141 (in Ukrainian)

\section{Information about the author:}

Alina Murtishcheva,

Candidate of Legal Sciences, Assistant Lecturer at the Department of State Construction, Yaroslav Mudryi National Law University 77, Pushkinskaya str., Kharkiv, 61024, Ukraine ORCID ID: orcid.org/0000-0001-6520-7297 


\section{IMPROVEMENT OF SOCIETY LEGAL CULTURE AS A BASIS FOR INCREASING TRANSPARENCY AND ACCOUNTABILITY OF THE JUDICIARY TO UKRAINIAN SOCIETY}

\section{Vitalina Novoselova}

\section{INTRODUCTION}

The reform of the judicial power in Ukraine towards its harmonization with international standards of legal proceedings provides, among other things, for increasing its transparency, strengthening its accountability to civil society and restoring confidence in it. Over the past five years, civil society in Ukraine has enjoyed a significant increase in affecting the state power performance in Ukraine in general, and the judiciary in particular. The perception and understanding of the judicial reform processes by public largely depend on the legal culture of the Ukrainian society. That is the reason why improvement of legal culture in the Ukrainian society can become a reliable basis for increasing the judiciary transparency to public in Ukraine. The influence of civil society on increasing transparency of the judiciary to a large extent hinge on theoretical understanding of the problems that arise in this area.

It is also necessary to take account of the fact that in modern democratic states, the influence of civil society institutions on the judiciary has been widely viewed as a powerful tool for establishing justice. The expediency of increasing transparency and accountability of the judiciary to civil society is recognized in most modern civilized states that adhere to the rule of law. That is why a number of international and European non-governmental organizations which deal with the judiciary are making significant efforts to spread this practice. According to the Madrid Principles on the Relationship between the Media and Judicial Independence, "It is the function and right of the media to gather and convey information to the public and to comment on the administration of justice, including cases before, during and after trial, without violating the presumption of innocence. The right to comment on the administration of justice shall not be subject to any special restrictions" 1 .

\footnotetext{
${ }^{1}$ The Madrid Principles on the Relationship between the Media and Judicial Independence. Retrieved from: http://www.fair.org.ua/content/library_doc/Annex_43_Court_Communications_ Book_UKR.pdf.
} 
In addition, the Member States of the Organization for Security and Cooperation in Europe have agreed on the use of such a form of influence as monitoring of legal proceedings - presence of observers from other OSCE participating States and NGOs at trials in their states. Nowadays, this practice has become widespread $^{2}$. At the same time, growing demands for judiciary performance by civil society institutions require a high level of legal culture from the public, their understanding of the processes in the judicial system, directions of its reform and their compliance with international standards of justice.

Thus, the aim of our research is to study the ways of improving society legal culture as a basis for increasing transparency and accountability of the judiciary to the Ukrainian society.

Research methods. In order to achieve scientific objectivity of the results, a complex of philosophical, general scientific and special scientific approaches and cognition methods was applied. Among the methodological approaches which determine the worldview orientation, we applied a civilizational approach (in order to clarify the essence of legal culture and justice) and a dialectical approach (when analysing the development of the judicial system and legal culture). The general scientific methods of cognition used in our work include the following: a system method (when studying the structure of the judicial system, its links), a functional method (for revealing the process of the judicial power and legal culture functioning) and a statistical method (for characterizing quantitative indicators of the judiciary). Among the special scientific methods used there is a formal dogmatic method (for study of the Ukrainian and international legislation), a comparative legal method (in the context of comparing the legal principles of transparency and accountability in the Ukrainian and international legislation), legal determinism (in justifying the ways of improving the legal culture of the Ukrainian society), etc.

Degree of the problem scientific development. The analysis of scientific literature shows that the problem of increasing transparency and accountability of the judiciary is the subject of research by many domestic and foreign scientists. In modern foreign scientific literature, the problems of transparency of state power, the judiciary in particular, have been addressed by many scholars, namely: J. Martin, J. Keane, M. Weber, K. Popper, J. Stiglitz, J. Habermas, etc., who examined the judiciary in the context of information openness and responsibility of judicial authorities. Despite application of different approaches, the authors share a common view that

\footnotetext{
${ }^{2}$ Reanimation Package of Reforms (2018) The Report of the Centre of Policy and Legal Reform on the results of the Program of the Judicial Process Monitoring in Ukraine, [Online], available at: https://rpr.org.ua/news/zvit-tsppr-za-rezultatamy-prohramy-monitorynhu-sudovyhprotsesiv-v-ukrajini./
} 
transparency is seen as openness of the administration system of society for the public and a guaranteed right of access to information. In other words, transparency is always linked to access to information.

In the Ukrainian scientific literature, the problems of transparency have only been addressed in recent years, however, the issues of openness and transparency of the judiciary are more traditional. Among Ukrainian scientists, a significant contribution to the study of these issues was made by the following scholars: V. Bryntsev, I. Marochkin, M. Vilhushynskyi, V. Horodovenko, I. Hrytsenko, P. Kablak, L. Moskvych, I. Nazarov, S. Prylutskyi, O. Romaniuk, T. Strus-Dukhnych and others. Another particular group includes the writings of scholars who examined the impact of civil society on the judiciary performance, namely Yu. Bytiak and I. Iakoviuk, Yu. Kalynovskyi, O. Todyka, M. Tsymbaliuk, Yu. Loboda, L. Herasin, O. Danylian, O. Dzoban, V. Kolisnyk, S. Maksymov, L. Udovyka and others.

At the same time, the analysis showed that the issues of improving legal culture of civil society as a basis for increasing transparency of the judiciary to civil society in Ukraine remained outside the focus of scientists. It should also be noted that a large number of monographic studies and scientific articles are devoted to the legal culture of the Ukrainian society. The scientific achievements of these scholars lay the methodological basis for the study of legal culture and enable understanding of the legal culture of various entities and persons relevant to the activities related to increasing the transparency and accountability of the judiciary to civil society in Ukraine.

\section{Legal culture of Ukrainian society and its legal subjects in the context of impact on the judiciary}

The concept of "legal culture of the Ukrainian society" is extremely broad and requires some clarification. Without going into the discussion about scientific approaches to the concept of "legal culture", which is beyond the framework of our research, we should note that in the context of the given writing we understand legal culture of the Ukrainian society as a system of legal values and ideals that reflect the state (level) of legal development of society members, which manifests itself at three levels, namely intellectual, emotional-psychological and behavioral, ensures their lawful behavior and legal activity. At the intellectual level, the legal culture of society presupposes knowledge of law, legal awareness and knowledge of information. At the emotional-psychological level, the legal culture of the Ukrainian society is embodied in a positive attitude to law and belief of citizens in the necessity and social utility of laws, the rule of law and order. At the behavioral level, the legal culture of society means the ability to use legal means, that is laws and other legal instruments in practice, ability to comply with prohibitions, exercise rights, perform duties, protect rights, freedoms and legitimate interests. 
The legal culture of society means both knowledge and understanding of law as well as presence of its members' own legal judgments, legal thinking about law, its social value, and ultimately orientation not only to lawful behavior but also to legal activity. It is legal activity as one of the highest and most complicated manifestations of the legal culture of the Ukrainian society that is important for increasing transparency and accountability of the judiciary to the public. At the same time, it is legal activity that is based on the knowledge and understanding of the processes of the judiciary functioning. The public that do not have the appropriate level of legal knowledge are not able to objectively assess the content and essence of the processes occurring in the judiciary activity and reform in Ukraine. The influence of this kind of public on the activity of the judicial power is able not only distort the other society members' perception of the judicial power, damage its reputation, reduce confidence in it, but also hinder its proper activity and effective reform in establishing the European standards of judicial procedure.

The limited amount of work allows us to focus on the legal culture of some legal culture subjects of the Ukrainian society which do not represent subjects of the judiciary directly, but are related to its activities, affect shaping of public opinion, the level of trust, transparency and accountability of the judiciary to civil society. We are talking about participants in legal proceedings (plaintiffs, defendants, witnesses, defenders), jurors, people's assessors.

In the context of the above-said, the legal culture of society should be considered as a unity of the legal culture of the Ukrainian society subjects (individual legal culture). In this case, it is primarily represented by the legal culture of Ukrainian citizens, with some of them being participants in legal proceedings. Citizens who have applied to the court for protection of their rights, freedoms and legitimate interests at the initial level show a certain confidence in the judicial power and seek to legally protect their rights.

According to judicial statistics, 3.4 million cases and materials were submitted to local and appellate courts in 2017, 3.8 million cases - in 2018. The courts of first instance mostly deal with cases and materials of criminal and civil proceedings. The statistics data show a sharp rise in the number of criminal cases submitted for consideration to local ordinary courts ${ }^{3}$. During 2018, courts of first instance and appellate courts considered 3.6 million cases (in 2017, 3.3 million cases respectively) and materials (84.4\% of the total number of cases pending in the courts, in $2017-86 \%$ respectively $)^{4}$.

\footnotetext{
3 Judicial Power of Ukraine (2018) The Review of the Data on the State of Justice Administration in 2018. p. 2.

4 Judicial Power of Ukraine (2018) The Review of the Data on the State of Justice Administration in 2018. p. 4.
} 
The increase in the total number of applications from citizens to protect violated rights indicates, on the one hand, an increase in the number of human rights violations, and on the other hand, a certain confidence in the judiciary as an effective mechanism for protecting violated rights. At the same time, the legal culture of the citizens, who applied to the court, can be transformed during the legal proceedings and after their completion. Proper organization of all procedures, transparency and openness of legal proceedings, timely receipt of comprehensive information on issues, in particular with regard to court fees, necessary details, legal proceedings, cases, in which obtaining public information is requested (through the court web page) as well as free legal assistance if necessary, respect for citizens not only from judges but also from court employees have a positive affect on the person being stressed emotionally and psychologically.

It is also necessary to take into account the fact that general perception and attitude to the judicial system activities by legal proceedings participants indirectly affects a wider range of relatives and friends of these persons, promotes or, vice versa, reduces the level of confidence in the judicial power. Certainly, after a court decision (or sentence) is issued, in the vast majority of cases, there is a party that is not satisfied with it. This party has legal ways to appeal the decision by filing an application. However, if the judge violates the terms of case consideration, unreasonably delays the case or does not take measures to consider the appeal or case within the period established by law as well as in case of unreasonably long breaks in court sessions, problems with access to public information in court, inappropriate behavior of the judge or employees of the court, citizens' perception and attitude to the judicial system becomes negative. Unfortunately, we should admit that despite some positive developments in the judicial power in Ukraine concerning its transparency and accessibility, not only the Ukrainian society but also national and international experts recognize the presence of system problems in the judiciary, miscarriage of justice.

The above statement can be confirmed by the statistical data on the applications of Ukrainian citizens to the ECHR. Applications from Ukraine account for $12.9 \%$ of the entire workload of the ECHR. In total, approximately 56,350 applications were registered with the ECHR as of December 31, 2018. According to this indicator, only two COE Member States, Russia and Romania (11745 and 8503 applications, respectively) outpaced Ukraine. At the same time, in terms of the ratio of the number of cases and the number of population, Ukraine is not among the leaders and only occupies the 20th place among the COE Member States ${ }^{5}$. The largest

5 The European Truth. International Security and Eurointegration of Ukraine (2019). Available at: https://www.eurointegration.com.ua/news/2019/01/24/7091973/. 
number of applications to the ECHR is registered from citizens of five states (Russia, Romania, Ukraine, Turkey, Italy), which make up almost $70 \%$ of the ECHR cases.

The above arguments and statistical data in the context of the problem under study give rise to several important points: first, the legal culture of a significant part of the Ukrainian society subjects is at a level where a person shows legal activity to protect violated rights, addressing domestic and international courts. Second, it should also be taken into account that some citizens use pre-trial and out-of-court methods of resolving legal conflicts, which indicates appropriate legal culture and certain confidence in the effectiveness of legal means for protection of violated rights. Third, judicial decisions, rulings, sentences, transparency of court's activities and the quality of the process organization at all stages affect the legal culture of citizens, who are participants in legal proceedings, and can increase confidence in the judiciary or, conversely, reduce it significantly. Fourth, a certain portion of citizens, who are not satisfied with judicial decisions, seek to disseminate information, in their opinion, on improper judiciary activities or miscarriage of justice (e.g. in the media), are willing to obtain further information on the activities of separate courts and judges, have an opportunity to influence the activities of the judiciary. In some cases, such citizens are involved in activities of public organizations engaged in the judiciary activities. Fifth, communicative culture of judges, defense lawyers and prosecutors is important for citizens, who participate in legal proceedings. For many of such citizens, the adversarial nature of the trial has a special effect, which is able to replace the rational components of the process with the emotional components of the speech (e.g. the call for "fair trial without applying unfair laws"). Appeal to the feelings of the audience, creation of emotional tension during the trial, use of theatrical effects have impact on ordinary citizens lacking expertise and critical thinking, cause erroneous emotional assessments and conclusions. Relevant information, knowledge, and critical legal thinking can prevent shaping biased perception and making the assessment of the process and activities of the judiciary as a whole.

The influence of the above-mentioned category of citizens, namely the trial participants, on the judiciary towards increasing its transparency and accountability is exercised, in particular, by filing complaints against judges to the Supreme Council of Justice and initiating disciplinary action. Citizens should take into account the provisions of Article 106 of the Law of Ukraine "On the Judiciary and the Status of Judges", which provides for the procedure for disciplinary proceedings in respect of a judge ${ }^{6}$. In addition, a citizen has

\footnotetext{
${ }^{6}$ The Law of Ukraine (Jul. 7, 2010) No. 2453-VI "On the Judiciary and the Status of Judges", Vidomosti Verkhovnoi Rady Ukrainy [The Official Bulletin of the Verkhovna Rada of Ukraine], 2016, No 31, Art. 545.
} 
the right to file a claim to the court for delivery of a knowingly unfair sentence, judgment, ruling or order by a judge (or judges) (Article 375 of the Criminal Code of Ukraine) ${ }^{7}$.

Participants in the legal proceedings also have other legal means of influencing the judiciary in order to increase its transparency and accountability. One of the levers of influence to increase the judiciary transparency can also be considered a citizen's request for public information, followed by disclosure of information in the media and drawing public attention to activities or behavior of a judge. However, the influence of individual citizens on the judicial power activity in Ukraine with regard to increasing its transparency and accountability can be considered significant on condition. Only under the condition of access and, at the same time, the interest of the media, an ordinary citizen can draw a wide response to a certain case. The legal activity of such a citizen, his knowledge, perseverance, integrity, a desire to use all available legal ways to protect violated rights and influence the judicial power (judge) in order to increase its transparency and accountability become extremely important. In addition, this activity requires significant psychological, physical, material and time resources. That is why the activities of public organizations' members, especially those of human rights organizations, are more effective in influencing the judiciary.

In the context of the research subject, special attention should be paid to the legal culture of jurors and people's assessors, who have a significant impact on the activities of the judiciary in general, increasing its transparency and accountability in particular. The introduction of the Institution of Jury Trial in Ukraine as one of the assets of legal development is intended to become an effective form of implementation of democracy in legal proceedings, a reliable basis for reform of the judiciary in accordance with the international and European legal principles and standards and a source of powerful development of the Ukrainian legal system.

Prior to investigating the legal culture of jurors, we should focus on defining their status. According to the Law of Ukraine "On the Judiciary and the Status of Judges", Article 58 "The Status of a People's Assessor and a Juror", "1. A people's assessor shall be a citizen of Ukraine who in situations prescribed by the procedural law shall adjudicate cases, as a member of a court panel, together with a judge, providing direct participation of the people in the administration of justice as required by the Constitution of Ukraine. When hearing and adjudicating cases, people's assessors shall exercise powers of a judge. 2. A juror shall be a citizen of Ukraine who in situations

\footnotetext{
${ }^{7}$ The Criminal Code of Ukraine (Apr. 05,2001) No. 2341-III, Vidomosti Verkhovnoi Rady Ukrainy [The Official Bulletin of the Verkhovna Rada of Ukraine], 2001, No 25-26, Art. 131.
} 
prescribed by the procedural law shall be engaged in administration of justice, providing direct participation of the people in the administration of justice as required by the Constitution of Ukraine"

The current legislation of Ukraine establishes requirements for a people's assessor and juror, namely: a people's assessor or juror must be a citizen of Ukraine who has reached the age of thirty and permanently resides in the territory covered by the jurisdiction of the respective court.

In Ukraine, a jury trial can be used for certain categories of civil and criminal proceedings. Article 59 "List of People's Assessors" and Article 60 "List of Jurors" of the Law of Ukraine "On the Judiciary and the Status of Judges" say that the lists of jurors shall be formed and approved by a decision of the respective local council for a two-year term upon the proposal of the territorial department of the State Judicial Administration. The list consists of citizens who permanently reside in the territory covered by the jurisdiction of the relevant court, meet the requirements specified below and have given consent to be jurors. That is, citizens can be jurors only on a voluntary basis.

The list of requirements for jurors is limited by the age criterion (from 30 to 65 years old), the criteria of territorial certainty and settlement, legal capacity, absense of criminal record, the command of the state language and a certain category of persons. The Law does not define any special requirements for moral or legal qualities of the citizens. According to Article 61 "The Requirements for a People's Assessor and Juror", "Citizens shall not be included in a list of people's assessors or a list of jurors if they: 1) were found by court to have limited legal capacity or legal incapacity; 2) are suffering from chronic mental or other diseases which prevent them from performing the duties of a people's assessor, juror; 3 ) have an outstanding or unquashed conviction; 4) are people's deputies of Ukraine (MPs), members of the Cabinet of Ministers of Ukraine, judges, prosecutors, law enforcement officers, military personnel, court staff, other public servants, officials of local governments, lawyers, notaries, members of the High Qualifications Commission of Judges of Ukraine, Supreme Council of Justice; 5) have been subject to administrative liability for committing a corruption offense within the year; 6) have reached the age of 65 ; 7) have no command of the state language" . Therefore, it should be concluded that any person who meets the established requirements can perform the functions of a juror. We should also

\footnotetext{
${ }^{8}$ The Law of Ukraine (Jul.7, 2010) No. 2453-VI "On the Judiciary and the Status of Judges", Vidomosti Verkhovnoi Rady Ukrainy [The Official Bulletin of the Verkhovna Rada of Ukraine], 2016, No 31, Art. 545.

${ }^{9}$ The Law of Ukraine (Jul.7, 2010) No. 2453-VI "On the Judiciary and the Status of Judges", Vidomosti Verkhovnoi Rady Ukrainy [The Official Bulletin of the Verkhovna Rada of Ukraine], 2016, No 31, Art. 545.
} 
pay attention to the fact that there is no requirement for jurors to have a full secondary or higher education.

The analysis shows that the current legislation of Ukraine does not establish moral or educational requirements for jurors involved in the administration of justice. The existing jury selection mechanism does not contain separate requirements for moral qualities, a cultural or educational background. It should be noted that the above criteria were taken into account in the mechanism that existed in the Soviet times and involved discussion of candidates at meetings of the labor collective, election of persons from among them who meet certain moral criteria and enjoy trust of the collective. Moreover, in legal science, scolars constantly emphasize on the importance of moral requirements for people's assessors, importance of high moral and human qualities of an assessor, which give him not only the legal right but also the moral one to judge other people. Among the personality traits contraindicated for judicial activity, scientists noted the following ones: prejudice, disrespect for people, rudeness, irascibility, arrogance, etc. ${ }^{10}$ First of all, a people's assessor must have such moral qualities as justice, responsibility for the fate of people, adherence to principles, honesty and consciousness. At the same time, such negative personal qualities as irresponsibility, injustice, unprincipledness, cruelty and propensity for deception are among the most unacceptable for people's assessors.

Therefore, the determinative qualities, which a juror, a people's assessor should have, are his ability and skills, common sense and some life experience. Secondary education, high moral and volitional qualities as well as legal activity were not among the determinative criteria for making a list of jurors and people's assessors. Hence, we can conclude that the legal culture of jurors and people's assessors when making lists can be identified as the legal culture of ordinary citizens, who form the legal culture of society, in the structure of which the emotional, psychological and behavioral levels, but not intellectual ones, prevail.

The peculiar feature of jurors and people's assessors' legal culture lies in the fact that it occupies a special place among other varieties and forms of legal culture. On the one hand, it is the legal culture of a person, whose legal position is aimed at strengthening the rule of law and order by performing various types of social activities. On the other hand, taking into account the legal activity of jurors and people's assessors as participants in the administration of justice, their legal culture, in its essence and content, is close

\footnotetext{
${ }^{10}$ Groshevoy Yu. M. (1975) Problemy formirovaniya sudeyskogo ubezhdeniya v ugolovnom sudoproizvodstve [The problems of shaping judicatory convictions in criminal proceedings]. Kharkiv: Vyshcha shkola.
} 
to the professional legal culture of a lawyer. That is why the problem of improving the legal culture of jurors and people's assessors is of great importance.

\section{Directions for improvement of society legal culture as a basis for increasing transparency of the judiciary to the Ukrainian society}

When justifying the directions for improving society legal culture as a basis for increasing transparency of the judiciary to the Ukrainian society, it is necessary to take into account several aspects, among them, in particular, are the following: first, the levels and structure of the legal culture of the subjects who exercise influence; second, the legal principles of transparency and accountability of the judiciary in Ukraine.

As it was noted above, legal culture exists at the intellectual, emotional, psychological and behavioral levels. The intellectual level of legal culture implies knowledge of law, legal awareness and knowledge of information. It is at this level that knowledge of law and understanding of the fact that the impact on the judiciary has clear legal boundaries established at the legislative level is extremely important. The legal framework for transparency and accountability of the judiciary in Ukraine is provided for by the Constitution of Ukraine, in particular Articles 32, 34, 129 ${ }^{11}$. Article 129 of the Constitution of Ukraine is fundamental, as, according to it, in the administration of justice, judges are independent and subject only to the law; the main principles of judicial proceedings are, in particular, openness of a trial and its complete recording by technical means.

The Laws of Ukraine "On Access to Public Information"12 and "On Access to Court Decisions"13 also apply to the context of directions and activity forms of civil society institutions in increasing transparency and accountability of the judiciary. Thus, Article 3 of the Law of Ukraine "On Access to Public Information"provides for the guarantees of observance of the right to access to public information, namely: transparency and openness of the activities of government agencies; free receipt, distribution and any other

${ }^{11}$ The Constitution of Ukraine (June 28, 1996), Vidomosti Verkhovnoi Rady Ukrainy [The Official Bulletin of the Verkhovna Rada of Ukraine], 1996, No 30, Art. 141, (as amended by the Law of Ukraine "On Amendments to the Constitution of Ukraine (concerning justice)" (June 2, 2016), Vidomosti Verkhovnoi Rady Ukrainy [The Official Bulletin of the Verkhovna Rada of Ukraine], 2016, No 51, p. 8, Art. 1799).

${ }^{12}$ The Law of Ukraine (Jan. 13, 2011) No. 2939-VI “On Access to Public Information”, Vidomosti Verkhovnoi Rady Ukrainy [The Official Bulletin of the Verkhovna Rada of Ukraine], 2011, No 32, Art. 314.

${ }^{13}$ The Law of Ukraine (Dec. 22, 2005) No. 3262-IV "On Access to Court Decisions", Vidomosti Verkhovnoi Rady Ukrainy [The Official Bulletin of the Verkhovna Rada of Ukraine], 2006, No 15, Art. 128. 
use of information that was provided or made public in accordance with this Law, except for restrictions established by the law; equality, regardless of the race, political, religious and other beliefs, gender, ethnic and social origin, property status, place of residence, language or other characteristics ${ }^{14}$.

The rules on the publicity of legal procedure are also contained in the procedural legislation: the Articles of the Civil Code of Ukraine (Article 296 The Right to Use the Name, Article 302 The Right to Information) ${ }^{15}$; the Civil Procedure Code of Ukraine (Article 7 Publicity of the Trial, Article 8 Transparency of Information on the Trial, Article 14 The Unified Judicial Information and Telecommunication System ${ }^{16}$; the Code of Administrative Procedure of Ukraine (Article 10 Publicity of the Administrative Procedure, Article 11 Transparency of Information on the Trial) ${ }^{17}$; the Economic Procedure Code of Ukraine (Article 8 Publicity of the Economic Procedure, Article 11 Transparency of Information on the Trial, Article 6 The Unified Judicial Information and Telecommunication System) ${ }^{18}$; the Criminal Procedure Code of Ukraine (Article 27 Publicity and Openness of Court Proceedings and Complete Recording Using Technical Means of a Court Session and Legal Proceedings) ${ }^{19}$.

Analyzing and summarizing their contents, we can distinguish the three main aspects of transparency: 1) the duty of the court to ensure publicitytransparency of court proceedings, which is implemented by placing ads on the time, day and place of the hearing, allowing the parties to familiarise with the materials of the case; 2) the right of parties to a public hearing of the case, which is their right to an open trial, awareness about the contents of the claims and objections of the parties, acquaintance with the case materials, the right to be heard at the trial, etc.; 3) the right of those who wish

14 The Law of Ukraine (Jan. 13, 2011) No. 2939-VI "On Access to Public Information", Vidomosti Verkhovnoi Rady Ukrainy [The Official Bulletin of the Verkhovna Rada of Ukraine], 2011, No 32, Art. 314.

${ }^{15}$ The Civil Code of Ukraine (Jan. 16, 2003) No. 435-IV, Vidomosti Verkhovnoi Rady Ukrainy [The Official Bulletin of the Verkhovna Rada of Ukraine], 2003, No. 40-44, Art. 356.

${ }^{16}$ The Civil Procedure Code of Ukraine (Mar. 18, 2004) No. 1618-IV, Vidomosti Verkhovnoi Rady Ukrainy [The Official Bulletin of the Verkhovna Rada of Ukraine], 2004, No. 40-41, No 42, Art. 492.

${ }^{17}$ The Code of Administrative Procedure of Ukraine (Jul. 6, 2005) No. 2747-IV, Vidomosti Verkhovnoi Rady Ukrainy [The Official Bulletin of the Verkhovna Rada of Ukraine], 2005, No 35-36, No 37, Art. 446.

18 The Economic Procedure Code of Ukraine (Nov. 6, 1991) No. 1798-XII, Vidomosti Verkhovnoi Rady Ukrainy [The Official Bulletin of the Verkhovna Rada of Ukraine], 1992, No 6, Art. 56.

19 The Criminal Procedure Code of Ukraine (Jul. 7, 2013) No.4651-VI, Vidomosti Verkhovnoi Rady Ukrainy [The Official Bulletin of the Verkhovna Rada of Ukraine], 2013, No 9-10, 11-12, No 13, Art. 88. 
to attend open court hearings, including representatives of the mass media, to disseminate and receive information about the court's activities. At the same time, it is necessary to distinguish the following types of trial transparency: 1) publicity for the parties (applies to persons, who are directly involved in the trial, the decision or sentence on which concerns or may concern their rights and obligations); 2) general publicity, which, in turn, is divided into certain types, the classification of which depends on the nature of the interest of entities and persons in obtaining information on the case; this is openness of court sessions: a) for persons who have a professional interest (representatives of the media, lawyers, law students, etc.); b) for persons who have a personal interest (relatives, close people, acquaintances of the parties to the process); c) for all disinterested persons (the public).

According to the current legislation, court decisions, court sessions and information on the cases considered by the court are open, except for cases specified by the legislation. No one shall be restricted in the right to obtain from the court information in the oral or written form on the results of his/her case consideration. Any person has the right to free access to a court decision in accordance with the procedure established by the legislation. Cases are considered in courts in public, except for cases established by law. Any person shall have the right to attend an open court session.

The legal grounds for publicity, transparency and accountability of the judiciary are also established by the provisions of the Law of Ukraine "On the Judiciary and the Status of Judges". In particular, Article 11 "Publicity and Transparency of Court Proceedings" states that court decisions, court sessions and hearing of cases in courts shall be open, except for cases specified by the procedural law. No one shall be restricted in the right to obtain from the court written or verbal information about the results of consideration of his/her case. Any person shall have the right to free access to a court decision in the manner prescribed by law ${ }^{20}$.

For the public, it is important to obtain information about the court as a public authority, judges, specific legal proceedings as well as to have access to court decisions. According to its content, information which can be obtained by citizens from the court, is grouped as follows: 1) information obtained by the court in the course of legal proceedings, and 2) information available to the court but not related to the administration of justice. An important element of judicial transparency is ensuring availability of judicial proceedings' results - court decisions. In Ukraine, in order to resolve the issue

20 The Law of Ukraine (Jul.7, 2010) No. 2453-VI "On the Judiciary and the Status of Judges", Vidomosti Verkhovnoi Rady Ukrainy [The Official Bulletin of the Verkhovna Rada of Ukraine], 2016, No 31, Art. 545. 
of ensuring access of individuals and legal entities to decisions of courts of all levels, the Law of Ukraine "On Access to Court Decisions" of December 22, 2005 (as amended) $^{21}$ is applied. The Law establishes the order of access to court decisions with the view of ensuring openness of activities of courts of general jurisdiction, predictability of court decisions and promotion of identical application of the legislation. The main issues regulated by the Law will be considered below.

Under the given Law, the Unified State Register of Court Decisions was created, which is an automated system for collecting, storing, protecting, recording, searching and providing electronic copies of judicial decisions. In order to increase transparency of the judiciary and level of public confidence in the judiciary, first and foremost, it is essential to ensure proper functioning of public access to court decisions. Users can access electronic copies of court decisions for free around the clock via the official web portal of the State Judicial Administration "The Judicial Power of Ukraine" 22 . Each individual or legal entity shall have general access to court decisions entered in the Register. At the same time, the Law contains provisions aimed at protecting personal information.

In addition to the general access to court decisions via the Register, it is also possible for persons concerned to have access to court decisions by contacting the office of the respective court. Thus, according to Article 9 of the Law of Ukraine "On Access to Court Decisions", a person who is not a party to the case, provided that the court decision concerns his/her rights, freedoms, interests or duties directly, can apply to the office of the respective court with a written application about the following: 1) granting an opportunity to familiarise with a judicial decision; 2) granting an opportunity to make copies of a court decision in the court building with the aid of own technical means; 3) making copies of a judicial decision by the judicial bodies $^{23}$.

There are a number of reasons for a person to be denied access to a court decision: 1) appeal to the court by a person who does not have procedural active legal capacity or a person on behalf of an interested person in the absence of the appropriate authority; 2) the case materials have been transferred to another court or stored in a state archive institution; 3 ) the court

${ }^{21}$ The Law of Ukraine (Dec. 22, 2005) No. 3262-IV "On Access to Court Decisions", Vidomosti Verkhovnoi Rady Ukrainy [The Official Bulletin of the Verkhovna Rada of Ukraine], 2006, No 15, Art. 128.

${ }^{22}$ The Judicial Power of Ukraine (2020). Available at: www.court.gov.ua.

${ }^{23}$ The Law of Ukraine (Dec. 22, 2005) No. 3262-IV "On Access to Court Decisions", Vidomosti Verkhovnoi Rady Ukrainy [The Official Bulletin of the Verkhovna Rada of Ukraine], 2006, No 15, Art. 128. 
decision does not directly affect the rights, freedoms, interests or obligations of this person. This list is not comprehensive.

Along with obtaining a court decision from the Register and directly from the court, court decisions can be published in printed matters and distributed in an electronic form. The law provides for official and unofficial publications of court decisions. Texts of court decisions are published in various collections, periodicals of courts, namely, in "The Court Appeal", "The Bulletin of Economic Justice", "The Bulletin of the Supreme Court of Ukraine", "The Decisions of the Supreme Court of Ukraine", "The Bulletin of the Constitutional Court of Ukraine", "The Judicial System and Legal Proceedings in Ukraine" as well as in journals and newspapers, in particular, in "The Legal Bulletin of Ukraine", "Yurydychna Gazeta", "Law\&Business", and others.

Openness, transparency and accountability of the judiciary are enshrined in a number of international and European legal acts. The rules established by the Council of Europe also define the restrictions on recording information in court proceedings by technical means (except for that carried out by the court). In particular, Recommendation Rec (2003) 13 of the Committee of Ministers to Member States on the provision of information through the media in relation to criminal proceedings says, "Live reporting or recordings by the media in court rooms should not be possible unless and as far as expressly permitted by law or the competent judicial authorities. Such reporting should be authorised only where it does not bear a serious risk of undue influence on victims, witnesses, parties to criminal proceedings, juries or judges". That is, the recording is prohibited, first of all, in order not to affect adversely the participants of the trial $^{24}$.

The legal way of influencing the judicial power is a citizen's claim to take disciplinary action against a judge. Citizens must take into account the provisions of Article 106 of the Law of Ukraine "On the Judiciary and the Status of Judges", which determine the procedure for disciplinary action against judges. Thus, the Law of Ukraine "On the Judiciary and the Status of Judges" defines disciplinary liability of a judge. According to Article 106 of the given Law, disciplinary proceedings against a judge may be initiated on the following grounds, among them, in particular, there are intentional actions or those resulting from negligence: a) unlawful denying a person's access to justice or other material violation of procedural law; violation of the principles of transparency and openness of legal proceedings; violation of the principles of equality of the legal proceedings participants before the law and court,

\footnotetext{
${ }^{24}$ Recommendation NR (2003) 13 of the Committee of Ministers to Member States, (Jul. 10, 2003) "On the provision of information through the media in relation to criminal proceedings".
} 
competitiveness of parties; failure to provide the accused with the right to defense, infringing upon the rights of other participants of legal proceedings; violation of the rules regarding recusal (self-recusal); unjustified delay or failure by a judge to consider an application, complaint or case within the time limit established by law; a judge's conduct that discredits the title of judge or undermines the authority of justice, in particular in matters of morality, honesty, integrity, compliance with the judge's lifestyle status, compliance with other standards of judicial ethics and the standards of conduct that ensure public confidence in the court; disrespect for other judges, lawyers, experts, witnesses or other participants of the proceedings; intentional violation or violation due to gross negligence by a judge who participated in making a judicial decision, of human rights and fundamental freedoms or other serious violation of law, which resulted in significant negative consequences; disclosure by a judge of the secrets protected by law; interference with the administration of justice by other judges; failure to submit or untimely submission for publication of the authorised person's declaration; declaration of false information; a judge's non-virtouos conduct; establishment of the inconsistencies of a judge's standard of living to the incomes declared; nonconfirmation by a judge of the legality of goods origin, etc. Judges may be subjected to disciplinary penalties, namely: a warning, reprimand, severe reprimand, suspension of a judge from the administration of justice, transfer of a judge to the court of a lower level and dismissal of a judge from office ${ }^{25}$.

Thus, citizens have certain legal means of affecting the judiciary in the context of increasing its transparency and accountability to society. At the same time, they are limited by the fundamental principles of the judiciary the principle of independence and autonomy, legal pemises for transparency and publicity.

Special attention should be paid to the question of how people's assessors and jurors influence the judiciary in the context of increasing its transparency and accountability, and therefore improving their legal culture. The peculiarity of the legal culture of jurors and people's assessors is that it occupies a special place among other varieties and forms of legal culture. On the one hand, it is the legal culture of a person, who, by performing various types of public activities, uses his legal stand to strengthen the rule of law and order, transparency and accountability of the judiciary to the Ukrainian society. On the other hand, taking into account the legal activity of jurors and people's assessors as participants in the administration of justice, their legal culture in its essence and content is close to the professional legal culture of a lawyer.

\footnotetext{
${ }^{25}$ The Law of Ukraine (Jul.7, 2010) "On the Judiciary and the Status of Judges", Vidomosti Verkhovnoi Rady Ukrainy [The Official Bulletin of the Verkhovna Rada of Ukraine], 2016, No 31, Art. 545.
} 
We believe that the legal culture of jurors and people's assessors is largely determined by their legal status. According to S. Ivanytskyi, "a complex, dualistic nature of the legal status of non-professional judges, who, on the one hand, are representatives of the people, and on the other hand, are members of a collective judicial body of state power, is derived from the functions and competence of the court. The binary position of a people's assessor in court proceedings provides for accumulation in his activities of state-assigned powers through his emotional-volitional and other personal qualities, which during the administration of justice are closely and inextricably related to the legal opportunities provided to him. Thus, the creative, interpretative component of work of a people's assessor, who does not have a special (psychological, etc) training for judicial activity, requires that his inherent human qualities should meet certain regulatory requirements, which ensure successful performance of his duties in the administration of justice" ${ }^{26}$.

Therefore, there arises a question about the presence of common and distinctive features in the legal culture of jurors as ordinary citizens of society and persons involved in legal activities (professional activity of a judge). The common features in the content of the legal culture of professional lawyers and legal culture of jurors are as follows: legal awareness and legal thinking; belief in the necessity and social utility of laws and regulations; lawful behavior; outcomes of lawful behavior and legal thinking. At the same time, the peculiarity of the legal culture of jurors and people's assessors consists in a certain level of development of the above-mentioned components of legal culture. Their level of legal activity is revealed in the readiness for initiatives in the legal area based on respect for law, conviction of necessity and fairness of legal norms, their voluntary implementation, proper knowledge of law, purposeful, positive, socially useful activity of the person. Of course, the legal culture of an individual juror is formed depending on the degree of assimilation and manifestation of the values of the society legal culture, specifics of professional activity, individual uniqueness of each person's creativity, life experience, etc. The cultural style of lawful behavior and constant compliance with the legal principles in lawful behavior are common features of jurors' legal culture.

In contrast to professional legal culture, whose bearers possess a high degree of knowledge and understanding of legal phenomena in the relevant areas of professional activity, critical and creative understanding of legal

${ }^{26}$ Moskvych L.M., Ivanytskyi S.O., Rusanova T.O. (2009) Pravovyi status nosiiv sudovoi vlady v Ukraini (profesiini suddi, narodni zasidateli, sud prysiazhnykh) [The legal status of judicial authorities in Ukraine (professional judges, people's assessors, jury). In Marochkin I.Ye. (ed.). Kharkiv: Finy (in Ukrainian). 
norms, laws, legal phenomena in terms of their humanistic, democratic and moral content, the legal culture of jurors and people's assessors is characterized by a lower level of knowledge. The ability to apply legal instruments - laws and other legal acts, use all the achievements of legal science and practice when making a particular court decision is also different for two groups. However, critical and creative interpretations of legal norms by jurors tend to be in line with those by professional lawyers, and in combination with knowledge in other fields, areas of science, life experience, high legal activity of jurors and people's assessors, they can ultimately contribute to making a weighted and grounded decision (verdict).

From the above stated it is obvious that in the legal culture of jurors and people's assessors, an essential role is played by legal consciousness in general and its evaluation function in particular. Performance of the evaluation function of legal awareness is based on the presence of certain legal knowledge, that is, the rational component of legal awareness, which is mainly the result of life experience, mental, intellectual activity of the person.

The structure of the legal consciousness and legal culture of jurors and people's assessors includes legal knowledge, legal values, legal concepts, legal conceptions of legal rights and obligations, legality, law and order, regulations, justice, legal feelings, etc. The formation of legal knowledge, values and conceptions of jurors takes place gradually and results from numerous cases of legal assessment as well as rational and emotional justification of positive significance of certain legal phenomena. It should be noted that legal assessment is organically linked to cognitive and emotional blocks of legal consciousness and revealed in appropriate rational-emotional forms.

Along with the legal consciousness as a rational component, an important role in the legal culture of jurors and people's assessors is played by the emotional-irrational component of legal consciousness, which exists in the form of a system of emotions, moods, experiences, feelings, etc. It serves as a certain basis for the rational and ideological area of legal awareness. Highlighting the legal culture of a society, a professional group or an individual, we should remember that in real life they are closely interrelated and correlate as the general, particular and individual. Legal culture as a social and legal phenomenon is single, and it is embodied in the legal culture of various groups, communities and individuals.

\section{CONCLUSIONS}

Based on our research, the following conclusions and generalizations can be made. Ukraine's entry into the European legal space is closely linked to the improvement of the Ukrainian society legal culture. Only on condition that the 
values of democracy, justice, responsibility and their protection are perceived and assimilated, the protection of human and civil rights and freedoms is effective. In this context, the issue of increasing the transparency and accountability of the judiciary to the Ukrainian society as one of the international standards of legal proceedings is of great importance. Achievement of this goal is impossible without improvement of society legal culture. Among a large number of society's legal culture subjects, special attention should be paid to the legal culture of the subjects related to the activities of the judiciary and influencing towards increasing its transparency and accountability.

Given the limited scope of work, the research subject was the legal culture of the Ukrainian society's members, who are not the judicial power subjects directly, but are related to its activities, namely: participants in trials (plaintiffs, defendants, witnesses, defenders), jurors and people's assessors. The legal culture of these subjects manifests itself at three levels: intellectual, emotional-psychological and behavioral, although to a different extent. The levels of legal culture and their significance for each group of subjects determine the direction and content of the improvement.

The analysis showed that the improvement of these subjects' legal culture involves not only assimilation of legal information, but also formation of legal knowledge, skills and critical legal thinking. At the stage of participation in the judicial process, it is important to be aware of the judiciary and its system activities and be able to obtain necessary information about the case. A higher level of legal culture is necessary when a person is legally active and seeks to influence the judiciary activities in order to increase its transparency and accountability by submitting a citizen's request for public information or filing a complaint against a judge. Involvement of citizens in the administration of justice and empowerment them as judges in case consideration and adjudgement involves intensive intellectual and emotional-volitional activities. The reasonableness and validity of the conclusions to be made by jurors and people's assessors depend primarily on the knowledge acquired empirically, life experience, ability to make assessments, emotional stability and balance. Given this, the problem of increasing the general level of the Ukrainian society legal culture, improving and optimizing the areas of legal attitude development and legal education, conducting trainings, lectures, and providing appropriate conditions for the duties performance by jurors and people's assessors during consideration of cases and making decisions is relevant.

Another important direction of improving the Ukrainian society legal culture in the context of increasing the transparency and accountability of the judiciary is educational work which aims to mobilize the public for solution of common problems or carry out trainings for specific target audiences, namely: 
conferences, seminars, round tables concerning certain issues; press conferences, programs on relevant topics in the mass media; analytical journalism; trainings on specific issues of an applied nature (e.g. establishment and operation of centres dealing with the issues of trial, ejustice, etc.); preparation and distribution of brochures among the citizens and other mechanisms for defending their rights in court. Along with the appropriate knowledge, organizational and communication skills, this kind of legal educational work requires its organizers to have a common active legal and civil position.

We should emphasize that optimization of the directions and forms of civil society institutions' activity in increasing the transparency and accountability of the judiciary to society is also inseparably linked with the activities of the judicial authorities, their interaction with civil society institutions. Creation of an electronic database of the Supreme Court positions with a convenient search engine, a new structured form of judicial decision, online broadcasting of all open court sessions, full communication with the parties via the Internet (electronic court), regular public reports to the public should become the essential directions for improvement of citizens' legal culture.

\section{SUMMARY}

The article deals with the issue of the ways of improving society legal culture as a basis for increasing transparency and accountability of the judiciary to the Ukrainian society.

The entry of Ukraine into the European legal space is closely linked to the improvement of the Ukrainian society legal culture. Only on condition that the values of democracy, justice, responsibility and their protection are perceived and assimilated, the protection of human and civil rights and freedoms is effective. In this context, the issue of increasing the transparency and accountability of the judiciary to the Ukrainian society as one of the international standards of legal proceedings is of great importance.

The subject of our research is the legal culture of those Ukrainian society's members, who are not the judicial power subjects directly, but are related to its activities, namely: participants in trials (plaintiffs, defendants, witnesses and defenders), jurors and people's assessors. The legal culture of these subjects is revealed at three levels: intellectual, emotional-psychological and behavioral, although to a different extent. The levels of legal culture and their significance for each group of subjects determine the direction and content of the improvement.

The article proves the improvement of these subjects' legal culture involves not only assimilation of legal information, but also formation of legal knowledge, skills and critical legal thinking. At the stage of participation in 
the judicial process, it is important to be aware of the judiciary and its system activities and be able to obtain necessary information about the case. A higher level of legal culture is necessary when a person is legally active and seeks to influence the judiciary activities in order to increase its transparency and accountability by submitting a citizen's request for public information or filing a complaint against a judge. Involvement of citizens in the administration of justice and empowerment them as judges in case consideration and adjudgement involves intensive intellectual and emotionalvolitional activities.

Educational work which aims to mobilize the public for solution of common problems or carry out trainings for specific target audiences represents an important direction of improving the Ukrainian society legal culture in the context of increasing the transparency and accountability of the judiciary.

The author notes that optimization of the directions and forms of civil society institutions' activity in increasing the transparency and accountability of the judiciary to society is also inseparably related to the activities of the judicial authorities, their interaction with civil society institutions.

\section{REFERENCES}

1. The Madrid Principles on the Relationship between the Media and Judicial Independence. Retrieved from: http://www.fair.org.ua/content/ library_doc/Annex_43_Court_Communications_Book_UKR.pdf.

(in Ukrainian) (accessed 20 November 2019).

2. Reanimation Package of Reforms (2018) The Report of the Centre of Policy and Legal Reform on the results of the Program of the Judicial Process Monitoring in Ukraine, [Online], available at: https://rpr.org.ua/news/zvittsppr-za-rezultatamy-prohramy-monitorynhu-sudovyh-protsesiv-v-ukrajini./ (in Ukrainian) (accessed 16 December 2019).

3. Judicial Power of Ukraine (2018) The Review of the Data on the State of Justice Administration in 2018. p. 2. Retrieved from: https://court.gov.ua/ userfiles/media/media/ogl_2018.pdf (in Ukrainian) (accessed 20 December 2019).

4. Judicial Power of Ukraine (2018) The Review of the Data on the State of Justice Administration in 2018. p. 4. Retrieved from: https://court.gov.ua/ userfiles/media/media/ogl_2018.pdf (in Ukrainian) (accessed 20 December 2019).

5. The European Truth. International Security and Eurointegration of Ukraine (2019). Available at: https://www.eurointegration.com.ua/ news/2019/01/24/7091973/ (in Ukrainian) (accessed 21 December 2019).

6. The Law of Ukraine (Jul.7, 2010) No. 2453-VI "On the Judiciary and the Status of Judges", Vidomosti Verkhovnoi Rady Ukrainy [The Official 
Bulletin of the Verkhovna Rada of Ukraine], 2016, No 31, Art. 545, [Online], available at: https://zakon.rada.gov.ua/laws/show/1402-19 (in Ukrainian) (accessed 10 January 2020).

7. The Criminal Code of Ukraine (Apr. 05,2001) No. 2341-III, Vidomosti Verkhovnoi Rady Ukrainy [The Official Bulletin of the Verkhovna Rada of Ukraine], 2001, No 25-26, Art. 131, [Online], available at: https://zakon.rada.gov.ua/laws/show/2341-14 in Ukrainian) (accessed 10 January 2020).

8. The Law of Ukraine (Jul.7, 2010) No. 2453-VI "On the Judiciary and the Status of Judges", Vidomosti Verkhovnoi Rady Ukrainy [The Official Bulletin of the Verkhovna Rada of Ukraine], 2016, No 31, Art. 545, [Online], available at: https://zakon.rada.gov.ua/laws/show/1402-19 (in Ukrainian) (accessed 10 January 2020).

9. The Law of Ukraine (Jul.7, 2010) No. 2453-VI "On the Judiciary and the Status of Judges", Vidomosti Verkhovnoi Rady Ukrainy [The Official Bulletin of the Verkhovna Rada of Ukraine], 2016, No 31, Art. 545, [Online], available at: https://zakon.rada.gov.ua/laws/show/1402-19 (in Ukrainian) (accessed 10 January 2020).

10. Groshevoy Yu. M. (1975) Problemy formirovaniya sudeyskogo ubezhdeniya $v$ ugolovnom sudoproizvodstve [The problems of shaping judicatory convictions in criminal proceedings]. Kharkiv: Vyshcha shkola. (in Russian)

11. The Constitution of Ukraine (June 28, 1996), Vidomosti Verkhovnoi Rady Ukrainy [The Official Bulletin of the Verkhovna Rada of Ukraine], 1996, No 30, Art. 141 (as amended by the Law of Ukraine "On Amendments to the Constitution of Ukraine (concerning justice)"(June 2, 2016), Vidomosti Verkhovnoi Rady Ukrainy [The Official Bulletin of the Verkhovna Rada of Ukraine], 2016, No 51, p. 8, Art. 1799), [Online], available at: https://zakon.rada.gov.ua/laws/main/254\%D0\%BA/96-\%D0\%B2\%D1\%80 (in Ukrainian) (accessed 8 January 2020).

12. The Law of Ukraine (Jan. 13, 2011) No. 2939-VI "On Access to Public Information", Vidomosti Verkhovnoi Rady Ukrainy [The Official Bulletin of the Verkhovna Rada of Ukraine], 2011, No 32, Art. 314, [Online], available at: https://zakon.rada.gov.ua/laws/show/2939-17 (in Ukrainian) (accessed 9 January 2020).

13. The Law of Ukraine (Dec. 22, 2005) No. 3262-IV "On Access to Court Decisions", Vidomosti Verkhovnoi Rady Ukrainy [The Official Bulletin of the Verkhovna Rada of Ukraine], 2006, No 15, Art. 128, [Online], available at: https://zakon.rada.gov.ua/laws/show/3262-15 (in Ukrainian) (accessed 9 January 2020).

14. The Law of Ukraine (Jan. 13, 2011) No. 2939-VI "On Access to Public Information", Vidomosti Verkhovnoi Rady Ukrainy [The Official Bulletin of 
the Verkhovna Rada of Ukraine], 2011, No 32, Art. 314, [Online], available at: https://zakon.rada.gov.ua/laws/show/2939-17 (in Ukrainian) (accessed 9 January 2020).

15. The Civil Code of Ukraine (Jan. 16, 2003) No. 435-IV, Vidomosti Verkhovnoi Rady Ukrainy [The Official Bulletin of the Verkhovna Rada of Ukraine], 2003, No. 40-44, Art. 356, [Online], available at: https://zakon.rada.gov.ua/laws/show/435-15 (in Ukrainian) (accessed 9 January 2020).

16. The Civil Procedure Code of Ukraine (Mar. 18, 2004) No. 1618-IV, Vidomosti Verkhovnoi Rady Ukrainy [The Official Bulletin of the Verkhovna Rada of Ukraine], 2004, No. 40-41, No 42, Art. 492, [Online], available at: https://zakon.rada.gov.ua/laws/show/1618-15 (in Ukrainian) (accessed 9 January 2020).

17. The Code of Administrative Procedure of Ukraine (Jul. 6, 2005) No. 2747-IV, Vidomosti Verkhovnoi Rady Ukrainy [The Official Bulletin of the Verkhovna Rada of Ukraine], 2005, No 35-36, No 37, Art. 446, [Online], available at: https://zakon.rada.gov.ua/laws/show/2747-15 (in Ukrainian) (accessed 9 January 2020).

18. The Economic Procedure Code of Ukraine (Nov. 6, 1991) No. 1798-XII, Vidomosti Verkhovnoi Rady Ukrainy [The Official Bulletin of the Verkhovna Rada of Ukraine], 1992, No 6, Art. 56, [Online], available at: https://zakon.rada.gov.ua/laws/show/1798-12 (in Ukrainian) (accessed 9 January 2020).

19. The Criminal Procedure Code of Ukraine (Jul. 7, 2013) No. 4651-VI, Vidomosti Verkhovnoi Rady Ukrainy [The Official Bulletin of the Verkhovna Rada of Ukraine], 2013, No 9-10, 11-12, No.13, Art. 88, [Online], available at: https://zakon.rada.gov.ua/laws/show/4651-17 (in Ukrainian) (accessed 9 January 2020).

20. The Law of Ukraine (Jul.7, 2010) No. 2453-VI "On the Judiciary and the Status of Judges", Vidomosti Verkhovnoi Rady Ukrainy [The Official Bulletin of the Verkhovna Rada of Ukraine], 2016, No 31, Art. 545, [Online], available at: https://zakon.rada.gov.ua/laws/show/1402-19 (in Ukrainian) (accessed 10 January 2020).

21. The Law of Ukraine (Dec. 22, 2005) No. 3262-IV "On Access to Court Decisions", Vidomosti Verkhovnoi Rady Ukrainy [The Official Bulletin of the Verkhovna Rada of Ukraine], 2006, No 15, Art. 128, [Online], available at: https://zakon.rada.gov.ua/laws/show/3262-15 (in Ukrainian) (accessed 9 January 2020).

22. The Judicial Power of Ukraine (2020). Available at: www.court.gov.ua. (accessed 9 January 2020). 
23. The Law of Ukraine (Dec. 22, 2005) No. 3262-IV “On Access to Court Decisions", Vidomosti Verkhovnoi Rady Ukrainy [The Official Bulletin of the Verkhovna Rada of Ukraine], 2006, No 15, Art. 128, [Online], available at: https://zakon.rada.gov.ua/laws/show/3262-15 (in Ukrainian) (accessed 9 January 2020).

24. Recommendation NR (2003) 13 of the Committee of Ministers to Member States, (Jul. 10, 2003) "On the provision of information through the media in relation to criminal proceedings", [Online], available at: https://zakon.rada.gov.ua/laws/show/994_870 (in Ukrainian) (accessed 10 January 2020).

25. The Law of Ukraine (Jul. 7, 2010) No. 2453-VI "On the Judiciary and the Status of Judges", Vidomosti Verkhovnoi Rady Ukrainy [The Official Bulletin of the Verkhovna Rada of Ukraine], 2016, No 31, Art. 545, [Online], available at: https://zakon.rada.gov.ua/laws/show/1402-19 (in Ukrainian) (accessed 10 January 2020).

26. Moskvych L.M., Ivanytskyi S.O., Rusanova T.O. (2009) Pravovyi status nosiiv sudovoi vlady v Ukraini (profesiini suddi, narodni zasidateli, sud prysiazhnykh) [The legal status of judicial authorities in Ukraine (professional judges, people's assessors, jury). In Marochkin I.Ye. (ed.). Kharkiv: Finy (in Ukrainian).

\section{Information abou the author:} Vitalina Novoselova, Chief specialist of the Zaporizhzhia Court of Appeal 10/8, Verkhnia str., Zaporizhzhia, 69032, Ukraine ORCID ID: orcid.org/0000-0003-3347-0837 


\section{AREAS OF PUBLIC ORGANIZATIONS' INFLUENCE ON LEGAL CULTURE AS A BASIS FOR CIVIL SOCIETY FORMATION: THEORETICAL AND LEGAL PREMISES}

\section{Larysa Udovyka}

\section{INTRODUCTION}

The experience of social development of modern democratic countries clearly shows that the level of civilizational development in general and that of political, legal and cultural development in particular, depend significantly on the functioning of civil society. Civil society as a socially organized structure, which is formed outside political structures but coordinated with the political organization of society, encourages settlement of public conflicts by legal means, "enables attraction of additional human, organizational, financial and technical resources in order to provide social and other socially significant services, promote decentralization of public administration and its quality improvement, reduce public expenditure and prevent corruption risks" 1 .

Amongnumerous subjects of civil society, an essential role is played by public organizations, which, among other things, influence the formation of citizens' legal culture and encourage them to take an active public and legal stand. In recent years, public organizations have initiated a number of activities aimed at reforming the judiciary, fighting corruption, establishing democracy and protecting human rights. In all public areas and at all levels, state and local, the role of public organizations has increased significantly. Their activities are aimed at reforms in public areas and e-government development, rise in transparency and accountability of public authorities to the Ukrainian society, promotion of European integration, provision of volunteer assistance to the Armed Forces of Ukraine and law enforcement agencies in the anti-terrorist operation, support of internally displaced persons. Therefore, the study of the theoretical and legal premises for the areas of public organizations' influence on legal culture as a basis of civil society formation is a crucial practical problem that requires a thorough comprehensive study.

It is also necessary to take into account the fact that globalization and integration processes, in which Ukraine is involved, intensify and deepen the

\footnotetext{
${ }^{1}$ National Strategy for the Support of Civil Society Development in Ukraine for 2016-2020 (2016). Approved by the President of Ukraine Decree No. 68/2016 of February 26, 2016 "On Support of Civil Society Development in Ukraine", [Online], available at: https://zakon.rada.gov.ua/laws/show/68/2016\#n20.
} 
interaction of national and global civil society. The complexity and prospects for the civil society development in Ukraine largely depend on the values and priorities, based on which the society will be developing, the degree of the European legal, political, and cultural values significance for Ukraine as well as on the fact which of these values will be promoted in the Ukrainian society. It is also important to expand the areas of cooperation between civil society organizations and Member States of the European Union.

Given the above-stated, the purpose of the present paper is to study the theoretical and legal premises for the areas of public organizations' influence on legal culture as a basis for civil society formation.

Research methods. To achieve this goal, we used an integrated set of philosophical, general scientific and special scientific approaches, methods and means of cognition in our research. The civilizational approach aims to determine the relationship between civil society and the state, clarify the role of legal culture in the formation and development of civil society. According to the fundamental laws of dialectics, the areas of public organizations' influence on the improvement of legal culture, their theoretical and legal premises caused by the contradictions between the real level of legal culture and the desirable, practical one are characterized by a certain correlation of quantitative and qualitative indicators. Among the general scientific methods of cognition, we used an axiological method (in the study of the principles and values of civil society, current legislation norms); a system structural method (in the research of the theoretical and legal premises for the areas of public organizations' influence, civil society structure, legal culture structure, their relationship); a functional method (for understanding the content of public organisations' activities, revealing the process of legal culture improvement, civil society functioning); a statistical method (for describing the quantitative indicators of public organizations' functioning). Special scientific methods used in our research involve a formal dogmatic method (for analysing the current legislation on regulation of public associations' activities, premises for civil society functioning in Ukraine), legal determinism (when grounding the areas of public associations' influence on legal culture, relationship between the level of legal culture and civil society development), and others.

Degree of the problem scientific development. Over the recent decade, the study of the role of public organizations in the development of civil society has aroused great interest among Ukrainian and foreign researchers. Special attention should be paid to the writings of the following foreign scholars: J. Habermas, P. Herrmann, G. Domanski, J.-L. Laville, D. Lewis, W. Powell, R. Putnam, T. Parsons, P. Play, D. Stone, A. Tocqueville, S. Feldman, J. Fischer, J.R. Hay, P. Schmitter, etc. Among the numerous works devoted to the study of civil society in general and public organizations in particular, we 
should highlight the achievements of Ukrainian scientists, namely O. Vashchuk, L. Voitova, A. Ivchenko, V. Kovalenko, A. Kolodii, A. Liasota, A. Matviichuk, V. Polokhalo, L. Usachenko, V. Stepanenko, M. Shevchenko, O. Yuldashev.The works addressingthe legal aspects of activities and relations of public organizations and public authorities are of special significance as well, namely the papers by U. Volynets, M. Vikhliaiev, V. Dementov, A. Halai, V. Kovalchuk, V. Kravchuk, S. Ponomarov, I. Stronianska, I. Tkachuk. However, we should take into account the enhancement of the content and nature of public associations' activities, transformation of the dynamics of civil society functioning in Ukraine, changes in the legal regulation of public associations' activities, complexity of their activities, which requires constant attention to this issue. The analysis of the scientific literature has shown that the theoretical and legal premises for the areas of public organizations' influence on legal culture as a basis of the civil society formation remain unexplored in legal science and should be subject to a thorough consideration.

\section{Legal premises for activities of public organizations as subjects of civil society}

The analysis of scientific sources shows that in modern social and humanitarian science there is no single, generally accepted understanding of the concept of civil society. One group of scientists interprets it as a set of interactions between individuals that have developed in the course of activity for protection of human rights and freedoms. The second group mainly includes institutionalized forms of such interactions in civil society, primarily public associations that have been established and registered in accordance with the current legislation. At the same time, they share a common point that creation of public organizations by citizens is the best possible way to exercise rights and freedoms as well as to satisfy various interests. Public associations are major subjects of civil society, given their goals, tasks and legal status.

The importance of public associations is recognized at international and national levels and enshrined in a number of international, European and national legal acts. The right to freedom of association is reaffirmed by other major international treaties on human rights, including the International Covenant on Civil and Political Rights ${ }^{2}$, the Convention for the Protection of

\footnotetext{
${ }^{2}$ UN General Assembly. International Covenant on Civil and Political Rights (December 16, 1966), United Nations. Treaty Series, vol. 999, p. 171, Article 22, [Online], available at: https://www.ohchr.org/en/professionalinterest/pages/ccpr.aspx
} 
Human Rights and Fundamental Freedoms ${ }^{3}$, the International Covenant on Economic, Social and Cultural Rights ${ }^{4}$, the American Convention on Human Rights, the Charter of Fundamental Rights of the European Union ${ }^{5}$, etc.

The right to freedom of association has been repeatedly confirmed by judicial practice at international and national levels. In addition, over the past few decades, a number of international governmental and non-governmental organizations have drafted and adopted many documents that proclaim the right to freedom of association. These documents include, inter alia, recommendations, resolutions, interpretative decisions of treaty bodies and reports of UN Special Rapporteurs. They laid the foundation for "soft" law and content of the Guidelines on Freedom of Association, which interpret the term "association" as "... an organized, independent, not-for-profit body based on the voluntary grouping of persons with a common interest, activity or purpose. An association does not have to have legal personality, but does need some institutional form or structure" 6 .

Among a wide range of problems, which public associations deal with, a significant part is related to the level of legal culture, namely human rights (combating discrimination), assistance in activities of national human rights institutions, protection of the rights of children, women, migrants, refugees, prevention and overcoming of violence in all forms, implementation of democratic reforms, provision of legal protection, socio-economic issues, humanitarian assistance, etc.

Thus, at the international level, there is a strong legal framework that regulates the right to freedom of association and lays the grounds for national law and legislation to recognize the right to association of individuals as an integral part of civil society. The Constitution of Ukraine and a number of laws are important in understanding the legal premises for the activities of public associations, which constitute, among other things, the premises for influencing legal culture as the basis for the civil society formation in Ukraine.

${ }^{3}$ Council of Europe. European Convention for the Protection of Human Rights and Fundamental Freedoms, as amended by Protocols Nos. 11 and 14, 4 November 1950, Article 11, [Online], available at: http://conventions.coe.int/treaty/Commun/QueVoulezVous.asp? NT $=005 \& C L=E N G$.

${ }^{4}$ UN General Assembly. International Covenant on Economic, Social and Cultural Rights (December 16, 1966), United Nations, Treaty Series, vol. 993, p. 3, Article 8.Retrieved from:https://www.ohchr.org/Documents/ProfessionalInterest/cescr.pdf

${ }^{5}$ European Union. Charter of Fundamental Rights of the European Union (October 26, 2012), 2012/C 326/02, Official Journal of the European Union, Article 12, [Online], available at: https://eur-lex.europa.eu/legal-

content/EN/TXT/?uri=uriserv:OJ.C_.2012.326.01.0391.01.ENG\&toc=OJ:C:2012:326:TOC

${ }^{6}$ The OSCE Office for Democratic Institutions and Human Rights (2015) Guidelines on Freedom of Association, p. 15. Retrieved from: https://www.osce.org/odihr/132371? download=true 
Thus, according to Article 36 of the Constitution of Ukraine, "Citizens of Ukraine have the right to freedom of association in political parties and public organizations for the exercise and protection of their rights and freedoms and for the satisfaction of their political, economic, social, cultural and other interests, with the exception of restrictions established by law in the interests of national security and public order, the protection of the health of the population or the protection of rights and freedoms of other persons" Article 37 of the Constitution of Ukraine provides for restrictions concerning the establishment and activities of political parties and public associations, which are prohibited"...if their programme goals or actions are aimed at the liquidation of the independence of Ukraine, the change of the constitutional order by violent means, the violation of the sovereignty and territorial indivisibility of the State, the undermining of its security, the unlawful seizure of state power, the propaganda of war and of violence, the incitement of interethnic, racial or religious enmity, and the encroachments on human rights and freedoms, and the health of the population. Political parties and public associations shall not have paramilitary formations" $"$.

There are some other Articles of the Constitution, which are fundamental for the legal regulation of public associations. They provide for the right to freedom of thought and speech, free expression of views and beliefs (Article 34), the right to file individual or collective petitions, or to personally appeal to bodies of state power, bodies of local self-government, and to the officials and officers of these bodies that are obliged to consider the petitions and to provide a substantiated reply within the term established by law (Article 40), the right to openness of a trial and its complete recording by technical means (Article 129), etc. ${ }^{9}$

7 The ConstitutionofUkraine(June 28, 1996), Vidomosti Verkhovnoi Rady Ukrainy [The Official Bulletin of the Verkhovna Rada of Ukraine], 1996, No 30, Art. 141 (asamended by the Law of Ukraine "On A mendments to the Constitution of Ukraine (concerning justice)" (June 2, 2016), Vidomosti Verkhovnoi Rady Ukrainy [The Official Bulletin of the Verkhovna Rada of Ukraine], 2016, No 51, p. 8, Art. 1799), [Online], available at: https://zakon.rada.gov.ua/ laws/main/254\%D0\%BA/96-\%D0\%B2\%D1\%80

${ }^{8}$ The Constitution of Ukraine (June 28, 1996), Vidomosti Verkhovnoi Rady Ukrainy [The Official Bulletin of the Verkhovna Rada of Ukraine], 1996, No 30, Art. 141 (asamended by the Law of Ukraine "On A mendments to the Constitution of Ukraine (concerning justice)" (June 2, 2016), Vidomosti Verkhovnoi Rady Ukrainy [The Official Bulletin of the Verkhovna Rada of Ukraine], 2016, No 51, p. 8, Art. 1799), [Online], available at: https://zakon.rada.gov.ua/laws/ main/254\%D0\%BA/96-\%D0\%B2\%D1\%80

${ }^{9}$ The Constitution of Ukraine (June 28, 1996), Vidomosti Verkhovnoi Rady Ukrainy [The Official Bulletin of the Verkhovna Rada of Ukraine], 1996, No 30, Art. 141 (asamended by the Law of Ukraine "On A mendments to the Constitution of Ukraine (concerning justice)" (June 2, 2016), Vidomosti Verkhovnoi Rady Ukrainy [The Official Bulletin of the Verkhovna Rada of Ukraine], 2016, No 51, p. 8, Art. 1799), [Online], available at: https://zakon.rada.gov.ua/laws/ main/254\%D0\%BA/96-\%D0\%B2\%D1\%80 
The concept and division of public associations is enshrined in Ukrainian legislation. Thus, in accordance withArticle 1 of the Law of Ukraine "On Public Associations", "A public association is a voluntary association of physical persons and/or legal entities under private law for the purpose of exercising and protecting rights and freedoms, and satisfying public, among them economic, social, cultural, environmental, and other interests. As far as its organizational and legal form is concerned, a public association is established as a public organization or a public union. A public organization is a public association the founders and members (participants) of which are physical persons. A public union is a public association, the founders of which are legal entities under private law and whose members (participants) may be legal entities under private law and/or physical persons" $" 10$.

The influence of public associations on the formation of legal culture as a basis for building civil society in Ukraine is primarily determined by the legal premises for their activities. Therefore, it is necessary to define in general terms the legal premises for public associations' activities in Ukraine. Thus, according to the Law of Ukraine "On Public Associations", Article 21 "The Rights of Public Associations", to implement its purpose (goals), a public association shall have the right to, in particular: "2) address bodies of state power, the bodies of power of the Autonomous Republic of Crimea, and local self-government bodies, their officers and employees with proposals (criticism), requests (petitions), and complaints in accordance with established procedure; 3) obtain, in accordance with established procedure, public information at the disposal of the authorities and other public information holders..."11 Thus, public associations have a fairly wide range of rights so that to achieve their goals and objectives, namely: to apply to public authorities in general, and the judiciary in particular, to obtain the necessary information. At the legislative level, there is the Regulation that public associations can jointly realize their goals and may engage in cooperation with foreign non-governmental organizations and international governmental organizations in compliance with the laws of Ukraine (Article 6 of the Law of Ukraine "On Public Associations")"

${ }^{10}$ The Law of Ukraine (Mar. 22, 2012) No. 4572-VI "On Public Associations", Vidomosti Verkhovnoi Rady Ukrainy [The Official Bulletin of the Verkhovna Rada of Ukraine], 2013, No 1, Art. 1, [Online], available at: https://zakon.rada.gov.ua/laws/show/4572-17

${ }^{11}$ The Law of Ukraine (Mar. 22, 2012) No. 4572-VI "On Public Associations", Vidomosti Verkhovnoi Rady Ukrainy [The Official Bulletin of the Verkhovna Rada of Ukraine], 2013, No 1, Art. 1, [Online], available at: https://zakon.rada.gov.ua/laws/show/4572-17(in Ukrainian) (accessed 03 January 2020).

12 The Law of Ukraine (Mar. 22, 2012) No. 4572-VI "On Public Associations", Vidomosti Verkhovnoi Rady Ukrainy [The Official Bulletin of the Verkhovna Rada of Ukraine], 2013, No 1, 
Summarizing various scientific views on public associations and given the fundamental principles of their organization, activities and peculiar features, a public association can be defined as voluntary, self-governing, independent, transparent, public, non-profit association of citizens, which is established to protect the rights and freedoms, based on common interests of its members and aimed at achieving socially significant goals, namely economic, legal, social, cultural, environmental, etc. Public organizations is represented by various professional unions, women's, youth, veterans', children's organizations, scientific, technical, cultural, educational, sports and other voluntary associations of citizens, creative unions, organizations, foundations, etc. The most significant role in affecting the state legal policy, functioning of public authorities, the judiciary in particular, is played by human rights public organizations, whose main goal is to protect the rights and freedoms of human and citizen, to efficiently supervise their observance and protection by the state, its bodies and officials.

In the context of the legal framework for public organizations' activities and their role in shaping legal culture, the Laws "On Access to Public Information"13, "On Access to Court Decisions"14, "On the Judiciary and the Status of Judges"15 are of great importance as well. Article 3 of the Law of Ukraine "On Access to Public Information" 16 provides for the guarantees of observance of the right to access to public information, namely: transparency and openness of the activities of government agencies; free receipt, distribution and any other use of information that was provided or made public in accordance with this Law, except for restrictions established by the law; equality, regardless of the race, political, religious and other beliefs, gender, ethnic and social origin, property status, place of residence, language or other characteristics.

In addition to the above laws, the legal premises for public associations' activities, which determine the areas of their influence on legal culture, are enshrined in other laws regulating certain types of public associations, such as

Art. 1, [Online], available at: https://zakon.rada.gov.ua/laws/show/4572-17(in Ukrainian) (accessed 03 January 2020).

${ }^{13}$ The Law of Ukraine (Jan. 13, 2011) No. 2939-V "On Access to Public Information", Vidomosti Verkhovnoi Rady Ukrainy [The Official Bulletin of the Verkhovna Rada of Ukraine], 2011, No 32, Art. 314, [Online], available at: https://zakon.rada.gov.ua/laws/show/2939-17.

${ }^{14}$ The Law of Ukraine (Dec. 22, 2005) No. 3262-IV "On Access to Court Decisions", Vidomosti Verkhovnoi Rady Ukrainy [The Official Bulletin of the Verkhovna Rada of Ukraine], 2006, No 15, Art.128, [Online], available at:https://zakon.rada.gov.ua/laws/show/3262-15.

${ }^{15}$ The Law of Ukraine(Jul.7, 2010) No. 2453-VI "On the Judiciary and the Status of Judges", Vidomosti Verkhovnoi Rady Ukrainy [The Official Bulletin of the Verkhovna Rada of Ukraine], 2016, No 31, Art. 545, [Online], available at: https://zakon.rada.gov.ua/laws/show/1402-19.

${ }^{16}$ The Law of Ukraine (Jan. 13, 2011) No. 2939-VI "On AccesstoPublicInformation", Vidomosti Verkhovnoi Rady Ukrainy [The Official Bulletin of the Verkhovna Rada of Ukraine], 2011, No 32, Art. 314, [Online], available at: https://zakon.rada.gov.ua/laws/show/2939-17. 
political parties, religious organizations, organizations engaged in professional self-government, etc. According to the Law of Ukraine "On Public Associations"(Article 2, para 3), "Individual aspects of regulation of social relations in the sphere of establishing and registering certain types of public associations in Ukraine, their functioning and termination may be determined by other laws"17.

Along with the legal regulation of public associations' activities at the constitutional and legislative levels, their activities are regulated by the charters of public associations. It is the charter where the purpose (goals) and activities of a public association as well as its interaction with other public organizations, including international ones, are defined. According to Article 9 of the Law of Ukraine "On Public Associations", the presence of the charter and its adoption at the constituent meeting is a premise for the establishment and registration of a public association.

Among the numerous public associations, whose activities are aimed at establishment of the rule of law, human rights protection, the judiciary functioning in Ukraine and, eventually, legal culture improvement, we cannot but mention the following ones: Centre for Democracy and Rule of Law (CEDEM), Centre of Policy and Legal Reform (CPLR), All-Ukrainian Civil Platform New Country, NGO" Public Lustration Committee", All-Ukrainian Public Organization "Ukrainian Bar Association" (UBA), NGO "Centre UA", Centre for Civil Liberties, Crimea SOS, Centre for Economic Strategy, DEJURE Foundation, Ukrainian Centre for European Policy.

It should be noted that among the goals and objectives of their activities, human rights organizations directly determine activities in legal education and legal awareness formation, development of civil society in Ukraine. Thus, the Centre for Democracy and Rule of Law (CEDEM), a think-and-act tank, which has been working in the civil society sector of Ukraine since 2005, is actively engaged in the Civil Society Initiative, which embodies the CEDEM mission in terms of development of the society of active and responsible citizens. Joining efforts, educating citizens and creating communities with responsible and proactive participants are the grounds for positive social transformations. The CEDEM also focuses on financial and institutional support for the Reanimation Package of Reforms, School of Communication (since 2019), where public activists are trained; provision of legal support and consultations for civil society coalitions, strengthening of democratic society in Ukraine; creation of platforms for training, meeting and uniting public

${ }^{17}$ The Law of Ukraine (Mar. 22, 2012) No. 4572-VI “On Public Associations", Vidomosti Verkhovnoi Rady Ukrainy [The Official Bulletin of the Verkhovna Rada of Ukraine], 2013, No 1, Art. 1, [Online], available at: https://zakon.rada.gov.ua/laws/show/4572-17. 
activists for massive projects ${ }^{18}$. Therefore, the CEDEM activities are related to organization and conduction of different legal educational activities which have a direct impact on the legal culture of members of public associations and entities subjected to the impact: social activists, civil servants, subjects of other public associations, the general public.

An important role in the improvement of citizens' legal culture is played by the public organization Centre of Policy and Legal Reform (CPLR). Despite the fact that the CPLR is not a conventional human rights organization, it is the value of human rights that determines its mission and goals. Since the moment of its establishment, the main goal of the CPLR has been development and promotion of implementation of the reform that will be able to ensure democracy and the rule of law in Ukraine, lead our country to EU membership in the future. The CPLR develops and facilitates reforms in Ukraine for strengthening democracy, the rule of law and good governance in the following areas: constitutionalism, governance and public administration, judicial proceedings, criminal justice, combating corruption and civil society development ${ }^{19}$. Taking into account the content and areas of this organization's activities, we can conclude that the main subjects affected are the Ukrainian society as a whole and its active citizens. Within a long time, the Centre has been involved in the elaboration of important draft legal acts on reforms in the judiciary, access to public information, namely participation in the preparation of the draft law "On Access to Court Decisions" adopted by the Parliament in 2005 and currently applied for operation of the Unified State Register of Court Decisions; participation in drafting the Law "On Access to Public Information" developed in 2008 and adopted by the Parliament in 2011 after an extensive campaign by the media and public associations; involvement in the development of the legal reform concept and the draft law "On the Judiciary and the Status of Judges".

In the context of our research, subject the activities of the All-Ukrainian Civil Platform New Country deserve special attention ${ }^{20}$. Among the areas and relevant aspects of its activities there is strategic vision (development of the strategic vision, national idea, strategic vision of cities and regions);reform projects (reform strategy, public communication for reforms, searching and raising funds); reform teams (training of teams for reform implementation, social mobility for civil society activists).Consolidation of civil society (association based on strategic vision, integration of civil society, education, interaction platform for civil society, politicians, authorities, experts) is of great significance. The scope of this organization's activities is provided by

\footnotetext{
${ }^{18}$ Centre for Democracy and Rule of Law (2019), available at: https://cedem.org.ua/.

${ }^{19}$ Centreof Policy and Legal Reform (2019), available at: https://www.pravo.org.ua/ua/about/.

${ }^{20}$ All-Ukrainian Civil Platform New Country(2019), available at: http://novakraina.org/.
} 
cooperation with a number of international associations, in particular the European Endowment for Democracy, Civil Society Dialogue for Progress, UNDP, Konrad Adenauer Stiftung ${ }^{21}$.

It should be noted that cooperation with international NGOs is common for this organization. In Ukraine, a vast majority of public associations' activities aimed at promotion of legal reform, combating corruption, protection of human rights and freedoms, establishment of the rule of law and democracy are more or less related to the activities of international associations, their organizational and material assistance.

Due to the fact that after the Revolution of Dignity there arose the need for authorities cleansing, some public activists, journalists, lawyers, individual MPs, IT-experts initiated the establishment of a nongovernmental organization "Public Lustration Committee", the members of which developed the Law of Ukraine "On Government Cleansing"(Lustration Law),assured its adoption by the Verkhovna Rada of Ukraine and directed their activities towards public control over its implementation. They also initiated a competition to form a Public Lustration Council, the establishment of which is provided for by the Law. Among more than 500 applicants, the list of which was published for open access, the Public Lustration Council under the Ministry of Justice selected twelve persons. Among them, there were investigative journalists, bloggers and social activists $^{22}$. In accordance with the current legislation and general goals, the Committee cooperates with other public associations, namely AutoMaidan, Samooborona, the Open Dialogue Foundation (ODF) from Poland as well as with public authorities, in particular the Lustration Department of the Ministry of Justice of Ukraine, in order to increase the effectiveness of its activities. Among major activities of the Public Lustration Committee, the emphasis is placed on monitoring and analysis, which, in particular, involves screening the officials included in the Uniform Register of persons who are subject to the Law of Ukraine "On Government Cleansing"; informing about the beginning of inspections in various bodies, according to the Inspection Plan approved by the Cabinet of Ministers; tracking trials regarding the reinstatement of officials lustrated; checking officials who remained in office despite the Law requirements; exposing attempts to openly sabotage the Law by officials, recording attempts by officials to avoid lustration by the Public Lustration Council under the Ministry of Justice of Ukraine, which includes authoritative investigative journalists and public activists $^{23}$.

${ }^{21}$ All-Ukrainian Civil Platform New Country(2019), available at: http://novakraina.org/.

22 Public Lustration Committee (2019), available at: https://web.archive.org/web/ 20150601025003/http:/lku.org.ua/.

${ }^{23}$ Public Lustration Committee (2014) The Members of the Public Lustration Council Were Approved, [Online], available at: https://web.archive.org/web/20150501081321/; http:/lku.org.ua/press_articles/148. 
The analysis of the goals and content of the Committee's activities shows that their activities aim to increase the level of legal culture of the general public, statesmen and officials, fundamentally change legal culture and “... keep away from public governance those persons who made decisions, took actions or inaction (and/or contributed to their taking) facilitating power usurpation by the President of Ukraine Viktor Yanukovych and seeking to undermine the foundations of the national security and defence or violate human rights and freedoms. Lustration to be based on the following principles: the rule of law and lawfulness; openness, transparency and public accessibility; presumption of innocence; individual liability; and guarantees of the right to defence" 24 .

Along with public organizations established in recent years in connection with the Revolution of Dignity in Ukraine, which are engaged in legal education activities, organizations established in the early $20^{\text {th }}$ century are still effective and tend to extend their activities. Among them, special attention should be paid to the All-Ukrainian Public Organization "Ukrainian Bar Association"(UBA) ${ }^{25}$, which unites more than 7 thousand lawyers into an influential professional community. Along with the objectives of the legal profession development, introduction of ethical standards, protection of professional rights of UBA members, the areas of legislation improvement and human rights are among the most important ones. The UBA dynamism and activities are based on individual initiative and interest of its members. The UBA maintains relations with the Council of Bars and Law Societies of Europe (CCBE), the American Bar Association (ABA), and is a member of the International Bar Association (IBA) ${ }^{26}$.The analysis of the UBA's goals and activity areas provides grounds to state that to a large extent, its activities are aimed at improving the legal culture of lawyers and the public with active citizenship and legal position.

The limited volume of the present paper makes it impossible to review the content and activities of other public associations engaged in improvement of legal culture, namely NGO "Centre UA", Centre for Civil Liberties, Crimea SOS, Centre for Economic Strategy, DEJURE Foundation, Ukrainian Centre

${ }^{24}$ The Law of Ukraine (Sep. 16, 2014) No. 1682-VII "On Government Cleansing”, Vidomosti Verkhovnoi Rady Ukrainy [The Official Bulletin of the Verkhovna Rada of Ukraine], 2014, No 44, Art. 2041, [Online], available at: https://zakon.rada.gov.ua/laws/show/1682-18.

25 All-Ukrainian Public Organization "Ukrainian Bar Association" (2019), available at: https://uba.ua/ukr/about/(accessed 03 January 2020).

${ }^{26}$ The Law of Ukraine (Sep. 16, 2014) No. 1682-VII "On Government Cleansing", Vidomosti Verkhovnoi Rady Ukrainy [The Official Bulletin of the Verkhovna Rada of Ukraine], 2014, No 44, Art. 2041, [Online], available at: https://zakon.rada.gov.ua/laws/show/1682-18 (in Ukrainian) (accessed 05 January 2020). 
for European Policy, etc. Therefore, in order to identify the areas of influence on legal culture, summarization and systematization of the content and lines of public organizations' activities should be made.

\section{Areas of public organizations' influence on the legal culture of citizens as a basis for the civil society formation in Ukraine}

The need to study the areas of public organizations' influence on the legal culture of citizens as a basis for the civil society formation is due, among other things, to the fact that in recent years, not only has their number increased, but also their role in the Ukrainian society has expanded. The positive experience of public organizations has led to an increase of public confidence in them. According to a survey conducted by the sociological service of the Razumkov Centre from March 21 to 26, 2019, 46\% of respondents trusted public organizations; volunteer organizations were said to be the most trusted ones $(68 \%$ of respondents) ${ }^{27}$. According to a sociological survey conducted by the same Centre from October 4 to 9, 2019, among the state and public institutions, the Armed Forces of Ukraine are most trusted (75\% of respondents trusted them most often), the President of Ukraine (70\%) and volunteer organizations (69\% respectively $)^{28}$. Public trust in public associations has a positive impact on the perception of information they distribute, encourages cooperation, support and dissemination of the values of democracy and the rule of law.

The analysis and systematization of the experience of public organizations, especially of human rights organizations, which have the most significant impact on the legal culture improvement, provides the grounds to identify several main areas and the corresponding measures. Most of the areas and events given below are organized and held by members of public organizations independently or jointly with members of other public associations and the general public. It should be noted that a significant part of them is also held with participation of representatives of state authorities and local self-governments and reflected in the National Strategy for the Support of Civil Society Development in Ukraine for 2016-2020 29 .

${ }^{27}$ Razumkov Centre (2019), The Level of Trust in Public Institutions and Electoral Orientations of Ukrainian Citizens, [Online], available at: http://razumkov.org.ua/napriamky/ sotsiologichnidoslidzhennia/riven-doviry-do-suspilnykh-instytutiv-ta-elektoralni-oriientatsii-gromadian-ukrainy-2.

${ }^{28}$ Rasumkov Centre (2019), Citizens 'assessment of the situation in the country and the activities of the government, the level of trust in social institutions and politicians. The study conducted by the sociological service of the Razumkov Centre from 4 to 9 October 2019, [Online], available at: http://razumkov.org.ua/napriamky/sotsiologichni-doslidzhennia/otsinka-gromadianamy-sytuatsii-vkraini-ta-diialnosti-vlady-riven-doviry-do-sotsialnykh-instytutiv-ta-politykiv.

${ }^{29}$ National Strategy for the Support of Civil Society Development in Ukraine for 2016-2020 (2016). Approved by the President of Ukraine Decree No. 68/2016 of February 26, 2016 "On Support of Civil Society Development in Ukraine", [Online], available at: https://zakon.rada.gov.ua/ laws/show/68/2016\#n20. 
The main areas and activities of public organizations that influence legal culture include the following: 1) participation in consultations with executive authorities, local self-government bodies on draft legal acts; 2) participation in the formation of the procedure for initiating and holding local referendums; 3) organization and conduct of peaceful assemblies; 4) organization of public hearings, development and introduction of local initiatives, implementation of other forms of participatory democracy jointly with state authorities and local self-government bodies; 5) at the level of local authorities, initiation of public consultations, public examination of their activities and activities of their executive bodies and officials, utility companies, organizations and institutions; 6) participation in the mandatory public consultation process of drafting the State budget of Ukraine and local budgets; 7) participation in public examination of the activities in administrative services provision and activities of budgetary institutions providing social services; 8) work on the development of an effective tool for realizing the right of citizens to address local self-government bodies with e-petitions; 9) activities and measures aimed at inclusion of mandatory procedures for ensuring information transparency and openness in the regulations of local councils, including the issues of public involvement in the preparation of draft acts of public importance; 10) organization and implementation of a complex of measures aimed at enhancement of civic education of the population with regard to protection of their rights and articulation of their interests through different forms of participatory democracy; 11) activism and events to increase the application areas for public-private partnerships with participation of civil society associations; 12) activities in legal education aimed at inclusion of courses and topics on the issues of civil society development in the curricula of secondary, vocational and higher schools; 13) carrying out of measures to ensure the provision of methodological, consulting and organizational assistance to public authorities and local self-government bodies on issues of interaction with civil society associations, development of civil society; 14) holding of educational events and social advertising with regard to interaction of civil society institutions and public authorities, local selfgovernment bodies; 15) promotion of scientific research, publications and educational activities in the field of civil society development, protection of human rights and freedoms, promotion of the rule of law and democracy.

The above-mentioned areas and activities include analytical, scientific, consulting, educational, supervisory and organizational work of members of relevant public organizations. In particular, participation in the development of state policy in a certain area of public and legal relations as well as assistance in its proper implementation involves revealing and researching the problems of the state and legal development, analytical forecasting, 
developing concepts of relevant reforms, drafting legal acts, participating in working groups and commissions engaged in the development of draft laws, legal expertise of draft laws, initiating public campaigns, public hearings to support decision-making on certain issues, monitoring implementation of adopted laws, etc. The legal culture subjects being affected in this regard are civil servants, officials, employees of local self-government bodies and all those involved in the development of state policy. The effectiveness of such an impact largely depends on the level of knowledge, competence, professionalism and legal culture of public organizations' members. Therefore, it is extremely important for them to constantly improve their professional and cultural level.

For some public organizations, scientific and consulting activities, which aim to theoretically substantiate proposed changes and convey legal positions to decision-making subjects, is an essential area of work, which is of great significance in influencing the legal culture of both individual categories of citizens and the general public. This activity line involves writing of scientific and practical comments, practical manuals, textbooks, monographs and other scientific publications; translation of outstanding works of Western legal thought representatives with their subsequent publication; translation and publishing of foreign sources of legislation; preparation of expert opinions on requests of ministries, departments and public authorities regarding the decisions they have made. Provision of expert opinions and consultations covers a narrower range of subjects, while writing comments, practical manuals, monographs and articles covers a wider range of subjects. A separate large group consists of students, primarily future lawyers. The opportunity to familiarize themselves with practitioners and legal experts' opinions is quite important for them. In such cases, their legal culture can be transformed in the practical area of the acquired knowledge and skills application.

Educational activities with the view of mobilizing politicians and the public to solve common problems is another important area of public organizations' activity. This work includes holding open lectures, conferences, seminars, trainings (e.g., on issues of judicial process, edocument management at public authorities, etc.), round tables on certain issues, holding press conferences and participating in programmes on relevant topics in the mass media; writing and distributing information booklets and other materials on the mechanisms for asserting their rights in court, in relations with officials, etc. to the general public. In this case, the legal culture subjects being affected are the general public asserting active citizenship and involved in solving public issues.

In recent years, such type of public organizations' activity as monitoring the activities of authorities, the judiciary in particular, has extended 
significantly. State authorities are monitored with regard to observance of the Constitution and laws of Ukraine, obligations arising from the membership in the Council of Europe and conditions of European integration. Preparation and publication of monitoring reports, providing comments to the media with legal assessment of decisions and other events is of importance in such activities.

The above-mentioned areas and measures aimed at improvement of public authorities' efficiency, increase in the role and importance of civil society and improvement of the Ukrainian society's legal culture are not the only activities of public organizations. Special attention should be paid to their activities concerning the influence on the judicial power in Ukraine in the area of adoption of international and European standards of legal proceedings. It is generally recognized that trust in the judiciary lays the foundation for a high level of citizens' legal culture. The areas and forms of public organizations' influence on the judiciary activities in general as well as towards increasing its transparency and accountability in particular, are constantly expanding. At the same time, their influence is determined by the legal principles of transparency and accountability of the judiciary, on the one hand, and autonomy and independence of the judiciary, on the other. For increasing the efficiency of the Ukrainian society's influence on the judiciary towards enhancement of its transparency and accountability, it is extremely important for public organizations' members to have an appropriate level of legal culture, which enables objective assessment of the judiciary, identification of system issues and an effective leverage to increase transparency and accountability of the judiciary to the Ukrainian society.

Another important area of public organizations' influence on the judiciary in the context of increasing its transparency and accountability is scientific and consulting activities with a view of theoretical substantiation of the proposed changes and conveyance of legal positions to decision-making subjects, which consists in holding conferences, seminars, round tables on certain issues; holding press conferences, participating in programmes on relevant topics in the mass media; conducting trainings on specific issues of an applied nature (e.g., establishment and operation of centres on issues of the judicial process, electronic legal proceedings, etc.); writing and distributing brochures and other materials on the mechanisms for asserting their rights in court; writing scientific and practical comments, practical manuals, textbooks, monographs and other scientific publications; facilitating the translation and publication of outstanding works of the Western legal thought as well as of foreign sources of legislation; conveyance of legal positions on requests of judges of the Constitutional Court of Ukraine; preparation of expert opinions on requests of ministries and other public authorities regarding the decisions they have made. Along with the 
relevant knowledge, this type of legal education work requires their organizers to have organizational and communication skills as well as unity of their active citizen's stand and legal position.

In recent years, the most significant areas and measures of public organizations' influence on the judiciary, which have drastically affected the legal culture of the Ukrainian society, have been the following: participation of public organizations in creating the legal basis for introduction of private performers; advocating the establishment of the High Anti-Corruption Court of Ukraine; participation in the activities of the Public Integrity Council with regard to assessment of candidates to the new Supreme Court; participation in interviews with candidates to the High Qualification Commission of Judges of Ukraine and making conclusions about their good/bad faith; organization and conduct of a series of regional trainings on the issues of public influence on judicial reform; participation in analytical studies (in particular, the impact of the armed conflict on justice).

At this level, it is extremely important that legal culture of the subjects of influence (public organizations' members) should be at the highest level; they should have a sufficiently high level of knowledge and critical legal thinking. Their communication culture is also of importance, which, among other things, provides for the ability to conduct a discussion, justify their own position and consider critical comments of colleagues as well as for legal competence. Legal competence is not only the result of training, but also a performance characteristic of the subject's ability to perform legal activities, which is formed on the basis of the use of relevant knowledge, skills, experience, its existing values and stand in life. Legal competence is based on the fact that the law becomes a value, adherence to the norms is an internal belief of the individual, which allows him to objectively assess and solve the problems that arise in various spheres of public relations. As an integrated result of legal knowledge acquisition, it enables a person to holistically implement legal knowledge, relevant skills and values in practice, contains cognitive, value-motivational and practical-behavioral components, and is of an objective-subjective nature.

Public supervision and activity of public assessors are among the forms of public organizations' influence on judicial authorities. In this context, a striking example is establishment of the Institute of Public Assessors by the NGO Anti-Corruption Council within the framework of the Fair Trial project $^{30}$. The main objective of the Fair Trial project is supervision of the judiciary, protection of the ordinary citizen's rights in court against violations by the judiciary, court staff (court clerks, court administrators) and other trial

\footnotetext{
${ }^{30}$ Fair Trial (2020), available at: http://akrsud.kharkiv.ua/.
} 
participants (prosecutors, representatives of other state institutions). Public assessors use various methods in their work, namely: 1) requests to the judge and assistant judges in case of violations; 2) video recording of the trial; 3 ) analysis of court hearing conduct and judges' actions; 4) response to illegal actions and inaction of the judicial authorities; 5) assessment of individual judges' performance; 6) conclusions about fairness of sentences, decisions, rulings and definitions. At the same time, all observations and conclusions are covered on the website and in the Ukrainian media ${ }^{31}$.

Such activity of public assessors also requires a high legal culture, legal knowledge, skills, constant analysis of the current legislation, tracing changes related to the judiciary activities. Effective and high-quality performance of public assessors provides for the fact that they have a professional legal thinking of lawyer, which is characterized by certainty (an ability to determine a problem situation), efficiency, dynamism (an ability to navigate the situation), consistency, criticism, objectivity, depth and breadth, flexibility, etc. In this sense, the activity of public assessors is quite close to that of judicial observers in trial monitoring.

Global experience in the judiciary performance improvement shows that an effective and powerful tool for supporting judicial reform in many civilized democratic countries is trial monitoring, which has been widely recognized over the past decade". The participating States of the Organization for Security and Co-operation in Europe (OSCE) have agreed to accept as a confidence-building measure the presence of observers from other OSCE participating States and non-governmental organizations (NGOs) at proceedings before their courts. By systematic gathering of reliable information on trial conduct, these programmes aim to help States develop effective justice systems which ensure adjudication of cases in accordance with the rule of law and international fair trial standards" ${ }^{\prime 3}$. Among the main forms used in this area, we should highlight the training of almost 100 trial observers (in the spring and summer of 2017, 24 of them, together with 5 experts of the Centre of Policy and Legal Reform (CPLR), monitored 1,400 court sessions. The monitoring results are provided in the report ${ }^{33}$.

Observers' training, which combined trainings and quests in Kiev courts, was a positive experience aimed at improvement of their legal culture.

${ }^{31}$ Fair Trial (2020), available at: http://akrsud.kharkiv.ua/.

32 OSCE Office for Democratic Institutions and Human Rights (2015) Trial Monitoring. A Reference Manual for Practitioners. Retrieved from: https://www.osce.org/odihr/94216? download=true.

${ }^{33}$ Centre of Policy and Legal Reform (2018) Presentation report on the results of the trial monitoring programme in Ukraine. [Online], available at: https://pravo.org.ua/ua/news/ 20872698-prezentatsiyniy-zvit-za-rezultatami-programi-monitoringu-sudovih-protsesiv-v-ukrayini. 
Without such training and improvement of the general level of trial observers' legal culture, the quality and effectiveness of their performance would be incorrect. Therefore, the practice of conducting trainings for the public, whose activities are aimed at increasing the transparency and accountability of the judiciary to the Ukrainian society, requires to be further extended.

It should be noted that despite the absence of a long tradition of civil society institutions' influence on the judicial authorities in Ukraine, there are certain positive changes in the area of increasing transparency and accountability of the judiciary to the Ukrainian society, in particular creation of the e-database of the Supreme Court positions with a convenient search system and a newly-introduced well-structured form of judicial decision, clearer and more accessible. A special role is played by the introduction of online broadcasts of all open court sessions and full communication with the parties via the Internet (e-court). Thus, in the Ukraine Judiciary Development Strategy 2015-2019, e-justice is recognized as a strategic issue that contributes to access to justice and trial improvement ${ }^{34}$. Information technologies in legal proceedings are a key tool for improving access to justice, improving the efficiency of courts and increasing their transparency. Therefore, it is necessary to make significant efforts to introduce e-justice, improve it and strengthen the interaction between these information systems and those of other justice bodies. This will help to increase transparency and accountability of the judiciary to the public in Ukraine. A more intensive use of e-justice will enable citizens and civil society institutions to track and record trials as well as receive all relevant documentation by electronic means.

We should note that the above discussed areas and measures of public organizations' influence on legal culture are much wider. Thus, Rabadi Bsher Saddam Nabeel quite rightly focuses on the role of public organizations in supporting foreign students with formation of their legal culture, in particular, with regard to the issues of education and residence in Ukraine ${ }^{35}$. The legal basis for interaction between international and Ukrainian public associations, influence of international NGOs on the legal culture of the Ukrainian society and development of civil society in Ukraine, problems of improving the legal culture of certain categories and groups, in particular young people, displaced

${ }^{34}$ Ukraine Judiciary Development Strategy 2015-2019. Retrieved from: https://court.gov.ua/ userfiles/strategij.pdf.

${ }^{35}$ Rabad i (Bsher Saddam) Nabeel (2019) Rol hromadskykh orhanizatsii u formuvanni pravovoi kultury suspilstva [The role of public organizations in shaping the legal culture of society].Retrieved from: file:///C:/Users/\%D0\%90\%D0\%B4\%D0\%BC\%D0\%B8\%D0\%BD\% D0\%B8\%D1\%81\%D1\%82\%D1\%80\%D0\%B0\%D1\%82\%D0\%BE\%D1\%80/Downloads/781127536-1-PB.pdf. 
persons, forced migrants and foreigners, who reside in Ukraine may become the subject of separate studies in the context of public organizations.

\section{CONCLUSIONS}

The analysis made in our paper provides the grounds for making a number of conclusions and generalizations. The areas of public organizations' influence on legal culture as a basis for civil society formation are determined by the theoretical and legal premises for their activities. At the international level, there is a strong legal framework that regulates the right to freedom of association and provides the basis for the national law and legislation with the view of recognizing the right to association as an integral part of a democratic society. The analysis of the current legislation shows that the legal basis of public organizations' activities, their influence on civil society and legal culture are provided for by the Constitution of Ukraine (in particular, Articles 36, 37, 40), the Laws of Ukraine "On Public Associations", "On Access to Public Information", "On Access to Court Decisions", "On the Judiciary and the Status of Judges", etc.

Among the numerous public organizations, the activities of which are aimed at establishing the rule of law, protecting human rights, functioning of the judiciary in Ukraine, and eventually improving legal culture, we should single out human rights organizations. The main areas and activities of public organizations that influence legal culture include the following: organizing and conducting peaceful assemblies; organizing public hearings jointly with state authorities, developing and introducing local initiatives as well as implementing other forms of participatory democracy; participating in public examination of activities in provision of administrative services; organizing and carrying out complex measures aimed at improving civil legal awareness of the population concerning their rights and interests' protection through different forms of participatory democracy; performing legal education activities, etc. Special attention should be paid to the activities of public organizations in influencing the judiciary in Ukraine towards the adoption of the international and European standards of justice and improvement of citizens' legal culture with regard to judiciary functioning. One of the forms of public organizations' influence on the judicial authorities is public supervision and activity of public assessors. The above-mentioned areas and measures of public organizations' influence on legal culture are much wider. The legal basis for interaction between international and Ukrainian public organizations, international NGOs' influence on the legal culture of the Ukrainian society and civil society development in Ukraine, problems of improving the legal culture of certain categories and groups, in particular young people, displaced persons, forced migrants and foreigners, who reside 
in Ukraine, may become the subject of separate studies in the context of public organizations.

\section{SUMMARY}

The experience of social development of modern democratic countries clearly shows that the level of civilizational development in general and that of political, legal, and cultural development in particular, depend significantly on the functioning of civil society, which contributes to settlement of social conflicts by legal means. Public organizations play an important role among the many subjects of civil society.

The areas of public organizations' influence on legal culture as a basis for civil society formation are determined by the theoretical and legal premises for their activities. At the international level, there is a strong legal framework that regulates the right to freedom of association and provides the basis for the national law and legislation with the view of recognizing the right to association as an integral part of a democratic society.

The analysis of the current legislation shows that the legal basis of public organizations' activities, their influence on civil society and legal culture are provided for by the Constitution of Ukraine (in particular, Articles 36, 37, 40), the Laws of Ukraine "On Public Associations", "On Access to Public Information", "On Access to Court Decisions", "On the Judiciary and the Status of Judges", etc.

Among the numerous public organizations, the activities of which are aimed at establishing the rule of law, protecting human rights, functioning of the judiciary in Ukraine, and eventually improving legal culture, we should single out human rights organizations. The main areas and activities of public organizations that influence legal culture include the following: organization of public hearings, development and introduction of local initiatives, implementation of other forms of participatory democracy jointly with state authorities and local self-government bodies; at the level of local authorities, initiation of public consultations, public examination of their activities and activities of their executive bodies and officials, utility companies, organizations and institutions; organization and implementation of a complex of measures aimed at enhancement of civic education of the population with regard to protection of their rights and articulation of their interests through different forms of participatory democracy; activities in legal education, etc. Special attention should be paid to public organizations' activities in influencing the judiciary in Ukraine towards the adoption of the international and European standards of justice and improvement of citizens' legal culture with regard to judiciary functioning. One of the forms of public organizations' influence on the judicial authorities is public supervision and activity of public 
assessors. The above-mentioned areas and measures of public organizations' influence on legal culture are much wider. The legal basis for interaction between international and Ukrainian public associations, international NGOs' influence on the legal culture of the Ukrainian society and civil society development in Ukraine, problems of improving the legal culture of certain categories and groups, in particular young people, displaced persons, forced migrants and foreigners, who reside in Ukraine, may become the subject of separate studies in the context of public organizations.

\section{REFERENCES}

1. National Strategy for the Support of Civil Society Development in Ukraine for 2016-2020 (2016). Approved by the President of Ukraine Decree No. 68/2016 of February 26, 2016 "On Support of Civil Society Development in Ukraine", [Online], available at: https://zakon.rada.gov.ua/laws/show/ 68/2016\#n20(in Ukrainian) (accessed 10 January 2020).

2. UN General Assembly. International Covenant on Civil and Political Rights (December 16, 1966), United Nations. Treaty Series, vol. 999, p. 171, Article 22, [Online], available at: https://www.ohchr.org/en/professional interest/pages/ccpr.aspx (accessed 02 January 2020).

3. Council of Europe. European Convention for the Protection of Human Rights and Fundamental Freedoms, as amended by Protocols Nos. 11 and 14, 4 November 1950, Article 11, [Online], available at: http://conventions.coe.int/treaty/Commun/QueVoulezVous.asp?NT=005\&CL= ENG (accessed 22 June 2019).

4. UN General Assembly. International Covenant on Economic, Social and Cultural Rights (December 16, 1966), United Nations, Treaty Series, vol. 993, p. 3, Article 8.Retrieved from: https://www.ohchr.org/Documents/ ProfessionalInterest/cescr.pdf (accessed 02 January 2020).

5. European Union. Charter of Fundamental Rights of the European Union (October 26, 2012), 2012/C 326/02,Official Journal of the European Union,Article 12,[Online], available at: https://eur-lex.europa.eu/legalcontent/EN/TXT/?uri=uriserv:OJ.C_.2012.326.01.0391.01.ENG\&toc=OJ:C:2 012:326:TOC (accessed 05 January 2020).

6. The OSCE Office for Democratic Institutions and Human Rights (2015) Guidelines on Freedom of Association, p. 15. Retrieved from: https://www.osce.org/odihr/132371?download=true (accessed 15 December 2019).

7. The Constitution of Ukraine (June 28, 1996), Vidomosti Verkhovnoi Rady Ukrainy [The Official Bulletin of the Verkhovna Rada of Ukraine], 1996, No 30, Art. 141 (as amended by the Law of Ukraine "On Amendments to the Constitution of Ukraine (concerning justice)"(June 2, 2016), Vidomosti 
Verkhovnoi Rady Ukrainy [The Official Bulletin of the Verkhovna Rada of Ukraine], 2016, No 51, p. 8, Art. 1799), [Online], available at: https://zakon.rada.gov.ua/laws/main/254\%D0\%BA/96-\%D0\%B2\%D1\%80 (in Ukrainian) (accessed 03 January 2020).

8. The Constitution of Ukraine (June 28, 1996), Vidomosti Verkhovnoi Rady Ukrainy [The Official Bulletin of the Verkhovna Rada of Ukraine], 1996, No 30, Art. 141 (as amended by the Law of Ukraine "On Amendments to the Constitution of Ukraine (concerning justice)"(June 2, 2016), Vidomosti Verkhovnoi Rady Ukrainy [The Official Bulletin of the Verkhovna Rada of Ukraine], 2016, No 51, p. 8, Art. 1799), [Online], available at: https://zakon.rada.gov.ua/laws/main/254\%D0\%BA/96-\%D0\%B2\%D1\%80 (in Ukrainian) (accessed 03 January 2020).

9. The Constitution of Ukraine (June 28, 1996), Vidomosti Verkhovnoi Rady Ukrainy [The Official Bulletin of the Verkhovna Rada of Ukraine], 1996, No 30, Art. 141 (as amended by the Law of Ukraine "On Amendments to the Constitution of Ukraine (concerning justice)" (June 2, 2016), Vidomosti Verkhovnoi Rady Ukrainy [The Official Bulletin of the Verkhovna Rada of Ukraine], 2016, No 51, p. 8, Art. 1799), [Online], available at: https://zakon.rada.gov.ua/laws/main/254\%D0\%BA/96-\%D0\%B2\%D1\%80 (in Ukrainian) (accessed 03 January 2020).

10. The Law of Ukraine (Mar. 22, 2012) No. 4572-VI "On Public Associations", Vidomosti Verkhovnoi Rady Ukrainy [The Official Bulletin of the Verkhovna Rada of Ukraine], 2013, No 1, Art. 1, [Online], available at:https://zakon.rada.gov.ua/laws/show/4572-17 (in Ukrainian) (accessed 03 January 2020).

11. The Law of Ukraine (Mar. 22, 2012) No. 4572-VI "On Public Associations", Vidomosti Verkhovnoi Rady Ukrainy [The Official Bulletin of the Verkhovna Rada of Ukraine], 2013, No 1, Art. 1, [Online], available at: https://zakon.rada.gov.ua/laws/show/4572-17 (in Ukrainian) (accessed 03 January 2020).

12. The Law of Ukraine (Mar. 22, 2012) No. 4572-VI "On Public Associations", Vidomosti Verkhovnoi Rady Ukrainy [The Official Bulletin of the Verkhovna Rada of Ukraine], 2013, No 1, Art. 1, [Online], available at: https://zakon.rada.gov.ua/laws/show/4572-17 (in Ukrainian) (accessed 03 January 2020).

13. The Law of Ukraine (Jan. 13, 2011) No. 2939-VI "On Access to Public Information", Vidomosti Verkhovnoi Rady Ukrainy [The Official Bulletin of the Verkhovna Rada of Ukraine], 2011, No 32, Art. 314, [Online], available at: https://zakon.rada.gov.ua/laws/show/2939-17 (in Ukrainian) (accessed 03 January 2020). 
14. The Law of Ukraine (Dec. 22, 2005) No. 3262-IV “On Access to Court Decisions", Vidomosti Verkhovnoi Rady Ukrainy [The Official Bulletin of the Verkhovna Rada of Ukraine], 2006, No 15, Art. 128, [Online], available at: https://zakon.rada.gov.ua/laws/show/3262-15 (in Ukrainian) (accessed 03 January 2020).

15. The Law of Ukraine (Jul.7, 2010) No. 2453-VI "On the Judiciary and the Status of Judges", Vidomosti Verkhovnoi Rady Ukrainy [The Official Bulletin of the Verkhovna Rada of Ukraine], 2016, No 31, Art. 545, [Online], available at: https://zakon.rada.gov.ua/laws/show/1402-19 (in Ukrainian) (accessed 03 January 2020).

16. The Law of Ukraine (Jan. 13, 2011) No. 2939-VI "On Access to Public Information", Vidomosti Verkhovnoi Rady Ukrainy [The Official Bulletin of the Verkhovna Rada of Ukraine], 2011, No 32, Art. 314, [Online], available at: https://zakon.rada.gov.ua/laws/show/2939-17 (in Ukrainian) (accessed 03 January 2020).

17. The Law of Ukraine (Mar. 22, 2012) No. 4572-VI "On Public Associations", Vidomosti Verkhovnoi Rady Ukrainy [The Official Bulletin of the Verkhovna Rada of Ukraine], 2013, No 1, Art. 1, [Online], available at: https://zakon.rada.gov.ua/laws/show/4572-17 (in Ukrainian) (accessed 03 January 2020).

18. Centre for Democracy and Rule of Law (2019), available at: https://cedem.org.ua/(accessed 23 December 2019).

19. Centre of Policy and Legal Reform (2019), available at: https://www.pravo.org.ua/ua/about/(accessed 23 December 2019).

20. All-Ukrainian Civil Platform New Country (2019), available at: http://novakraina.org/(accessed 23 December 2019).

21. All-Ukrainian Civil Platform New Country (2019), available at: http://novakraina.org/(accessed 23 December 2019).

22. Public Lustration Committee (2019), available at: https://web.archive.org/web/20150601025003/http:/lku.org.ua/ (accessed 23 December 2019).

23. Public Lustration Committee (2014)The Members of the Public Lustration Council Were Approved, [Online], available at: https://web.archive.org/web/20150501081321/http:/lku.org.ua/press_articles/1 48 (in Ukrainian) (accessed 03 January 2020).

24. The Law of Ukraine (Sep. 16, 2014) No. 1682-VII "On Government Cleansing “, Vidomosti Verkhovnoi Rady Ukrainy [The Official Bulletin of the Verkhovna Rada of Ukraine], 2014, No 44, Art. 2041, [Online], available at: https://zakon.rada.gov.ua/laws/show/1682-18 (in Ukrainian) (accessed 05 January 2020). 
25. All-Ukrainian Public Organization “Ukrainian Bar Association”(2019), available at: https://uba.ua/ukr/about/(accessed 03 January 2020).

26. The Law of Ukraine (Sep. 16, 2014) No. 1682-VII "On Government Cleansing “, Vidomosti Verkhovnoi Rady Ukrainy [The Official Bulletin of the Verkhovna Rada of Ukraine], 2014, No 44, Art. 2041, [Online], available at: https://zakon.rada.gov.ua/laws/show/1682-18 (in Ukrainian) (accessed 05 January 2020).

27. Rasumkov Centre (2019), The Level of Trust in Public Institutions and Electoral Orientations of Ukrainian Citizens, [Online], available at: http://razumkov.org.ua/napriamky/sotsiologichni-doslidzhennia/riven-dovirydo-suspilnykh-instytutiv-ta-elektoralni-oriientatsii-gromadian-ukrainy-2(in Ukrainian) (accessed 05 January 2020).

28. Rasumkov Centre (2019), Citizens 'assessment of the situation in the country and the activities of the government, the level of trust in social institutions and politicians. The study conducted by the sociological service of the Razumkov Centre from 4 to 9 October 2019, [Online], available at: http://razumkov.org.ua/ napriamky/sotsiologichni-doslidzhennia/otsinka-gromadianamy-sytuatsii-v-krainita-diialnosti-vlady-riven-doviry-do-sotsialnykh-instytutiv-ta-politykiv

(in Ukrainian) (accessed 05 January 2020).

29. National Strategy for the Support of Civil Society Development in Ukraine for 2016-2020 (2016). Approved by the President of Ukraine Decree No. 68/2016 of February 26, 2016 "On Support of Civil Society Development in Ukraine", [Online], available at: https://zakon.rada.gov.ua/laws/ show/68/2016\#n20(in Ukrainian) (accessed 10 January 2020).

30. Fair Trial (2020), available at: http://akrsud.kharkiv.ua/ (accessed 12 January 2020).

31. Fair Trial (2020), available at: http://akrsud.kharkiv.ua/ (accessed 12 January 2020).

32. OSCE Office for Democratic Institutions and Human Rights (2015) Trial Monitoring. A Reference Manual for Practitioners. Retrieved from: https://www.osce.org/odihr/94216?download=true (accessed 12 January 2020).

33. Centre of Policy and Legal Reform (2018) Presentation report on the results of the trial monitoring programme in Ukraine. [Online], available at: https://pravo.org.ua/ua/news/20872698-prezentatsiyniy-zvit-za-rezultatamiprogrami-monitoringu-sudovih-protsesiv-v-ukrayini(in Ukrainian) (accessed 10 January 2020).

34. Ukraine Judiciary Development Strategy 2015-2019. Retrieved from: https://court.gov.ua/userfiles/strategij.pdf(in Ukrainian) (accessed 14 January 2020). 
35. Rabadi (Bsher Saddam) Nabeel (2019) Rol hromadskykh orhanizatsii u formuvanni pravovoi kultury suspilstva [The role of public organizations in shaping the legal culture of society]. Retrieved from: file://C:/Users/ \%D0\%90\%D0\%B4\%D0\%BC\%D0\%B8\%D0\%BD\%D0\%B8\%D1\%81\%D1\% 82\%D1\%80\%D0\%B0\%D1\%82\%D0\%BE\%D1\%80/Downloads/7811-275361-PB.pdf. (in Ukrainian) (accessed 14 January 2020).

\section{Information about the author:}

Larysa Udovyka, Dr. hab. in Law, Professor, Head of the Department of the Law Faculty, Zaporizhzhia National University 10/8, Verkhnia str., Zaporizhzhia, 69032, Ukraine ORCID ID: orcid.org/0000-0001-9260-4474 
NOTES 
NOTES 
Publishing house "Liha-Pres"

9 Kastelivka str., Lviv, 79012, Ukraine 44 Lubicka str., Torun, 87-100, Poland

Printed by the publishing house "Liha-Pres"

Passed for printing: February 7, 2020.

A run of 150 copies. 